INSTITUTO DE PESQUISAS ENERGÉTICAS E NUCLEARES

Autarquia associada à Universidade de São Paulo

\title{
ESTUDOS ESPECTROSCÓPICOS DOS COMPLEXOS EURÓPIO-TETRACICLINAS E SUAS APLICAÇÕES NA DETECÇÃO \\ DE PERÓXIDO DE HIDROGÊNIO E PERÓXIDO DE URÉIA
}

\author{
ANDREA NASTRI GRASSO
}

Dissertação apresentada como parte dos requisitos para obtenção do Grau de Mestre em Ciências na Área de Tecnologia Nuclear Materiais.

Orientadora:

Profa. Dra. Lilia Coronato Courrol

SÃO PAULO

2010 


\section{AGRADECIMENTOS}

Gostaria de agradecer minha orientadora Lilia C. Courrol, minha família por sempre apoiar as minhas escolhas e especialmente minha amiga Luciane $\mathrm{S}$. Teixeira por tornar esta etapa mais fácil. 


\title{
ESTUDOS ESPECTROSCÓPICOS DOS COMPLEXOS EURÓPIO- TETRACICLINAS E SUAS APLICAÇÕES NA DETECÇÃO DE PERÓXIDO DE HIDROGÊNIO E PERÓXIDO DE URÉIA
}

\author{
Andrea Nastri Grasso
}

RESUMO

Neste trabalho foram estudadas as propriedades espectroscópicas do ín európio trivalente complexado à componentes da família das tetraciclinas, a clorotetraciclina, oxitetraciclina e metaciclina, em presença de peróxido de hidrogênio e peróxido de uréia. Para isso foram obtidos os parâmetros ópticos de absorção, emissão, tempo de vida e construídas curvas de calibração para os espectros de luminescência. Realizaram-se experimentos com compostos inorgânicos juntamente com os complexos a fim de verificar a interferência dos mesmos. Também foram realizados estudos para determinação de glicose utilizando os complexos európiotetraciclinas como biossensor. Os resultados mostram que os complexos európiotetraciclinas apresentam um espectro de emissão bem definido na região do visível e, na presença de peróxido de hidrogênio ou peróxido de uréia, há um aumento sensível na luminescência e tempo de decaimento. Assim, os complexos európiotetraciclinas estudados podem ser utilizados como biossensores para determinação dos peróxidos de hidrogênio e uréia, sendo um método realizado em temperatura ambiente, direto e de baixo custo. Um método indireto para determinação de glicose foi estudado através da adição da enzima glicose oxidase aos complexos európiotetraciclinas na presença de glicose no qual há como produto o peróxido de hidrogênio.

Palavras-Chave: európio; tetraciclina; peróxido de hidrogênio; peróxido de uréia; glicose. 


\title{
SPECTROSCOPIC STUDIES OF EUROPIUM-TETRACYCLINES COMPLEXES AND THEIR APPLICATIONS IN DETECTION OF HYDROGEN PEROXIDE AND UREA PEROXIDE.
}

\author{
Andrea Nastri Grasso
}

\begin{abstract}
In this work were studied the spectroscopic properties of trivalent europium ion complexed with components of tetracycline family, chlorotetracycline, oxytetracycline and metacycline, in the presence of hydrogen peroxide and urea peroxide. Optical parameters were obtained such as absorption, emission, lifetime and calibration curves were constructed for luminescence spectra. Experiments were carried out with both inorganic compounds and europium-tetracyclines complexes in order to verify possible interferences. Studies for glucose determination were also described using europium-tetracyclines complexes as biosensors. Results show that europiumtetracyclines complexes emit a narrow band in the visible region and, in the presence of hydrogen peroxide or urea peroxide there is a greater enhancement in their luminescence and lifetime. Thus, europium-tetracyclines complexes studied can be used as biosensors for hydrogen and urea peroxides determination as a low cost and room temperature method. An indirect method for glucose determination was studied by adding glucose oxidase enzyme in europium-tetracyclines complex in the presence of glucose promoting as product hydrogen peroxide.
\end{abstract}

Key-words: europium; tetracycline; hydrogen peroxide; urea peroxide; glucose. 


\section{SUMÁRIO}

Página

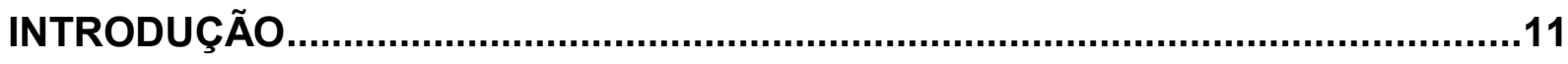

OBJETIVOS

REVISÃO DA LITERATURA

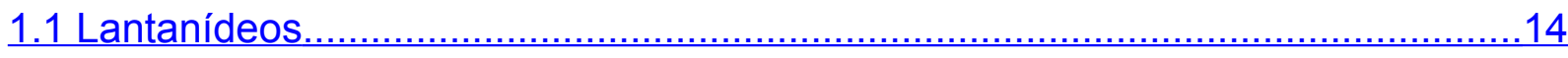

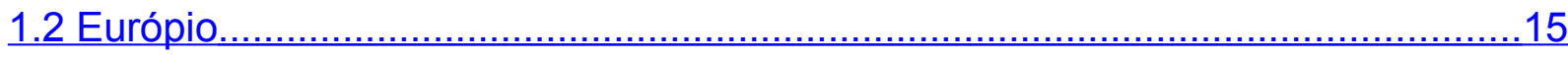

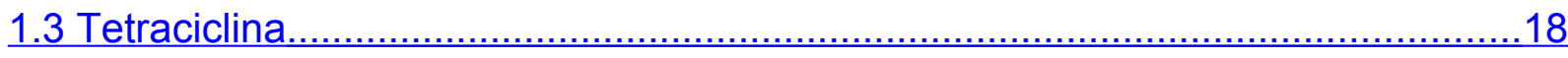

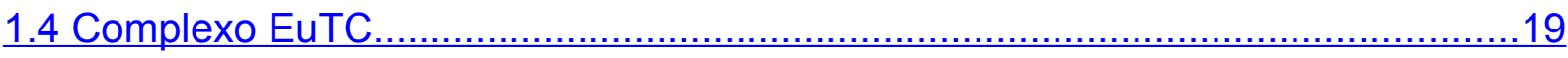

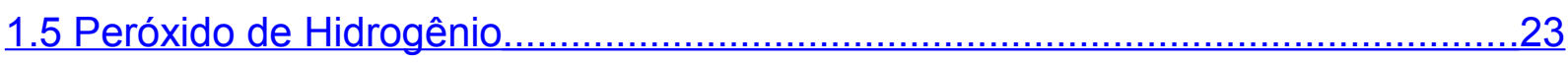

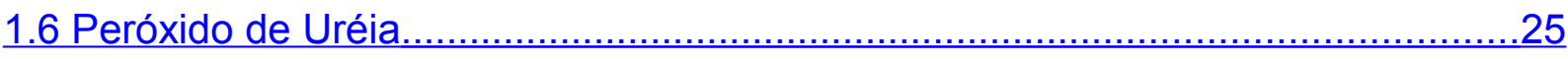

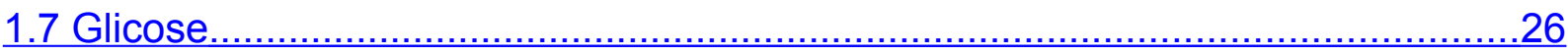

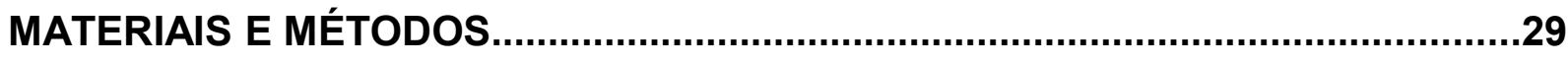

1.8 Reagentes e Solventes.................................................................................... 30

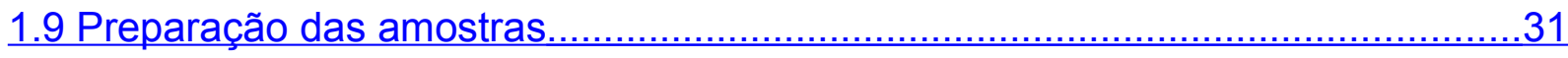

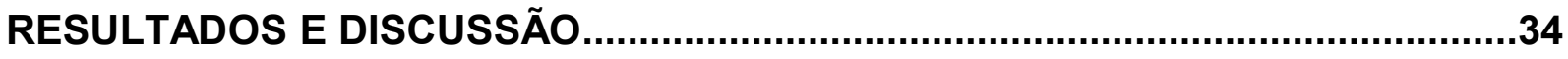

1.10 Estudos dos Reagentes e Complexos Európio-Tetraciclinas..............................34

1.11 Determinação das curvas de calibração.......................................................... 38

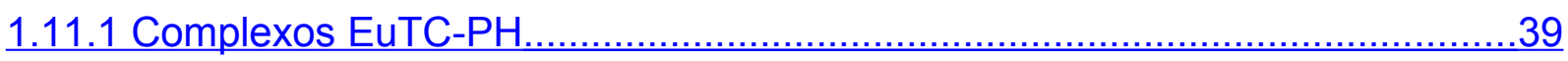

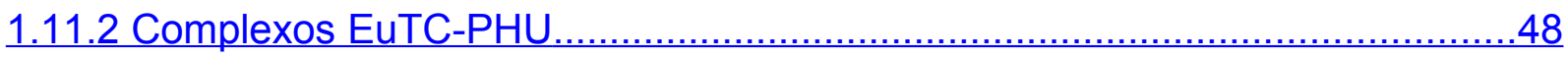

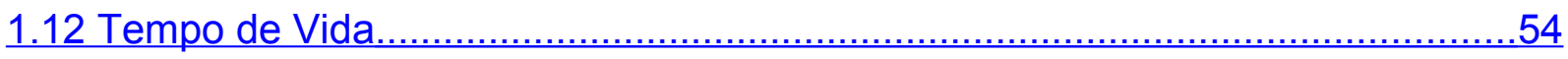

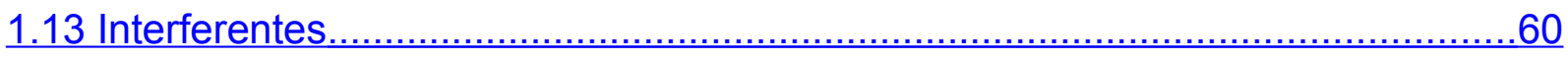

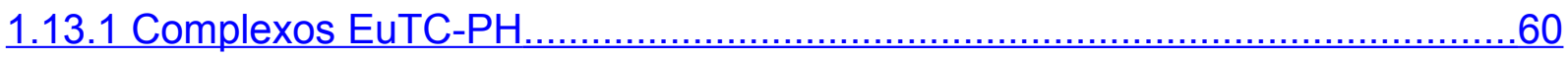

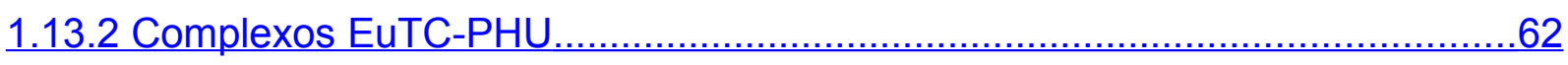

1.14 Complexos EuTC com Glicose......................................................................64

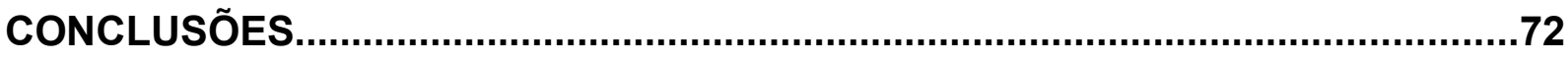

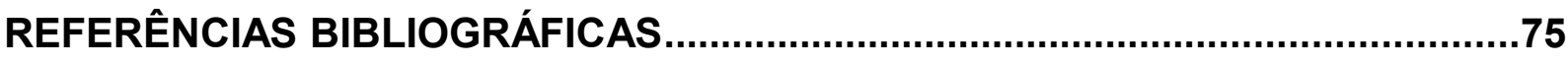




\section{LISTA DE TABELAS}

Tabela 1 - Métodos para determinação de peróxido de hidrogênio4,52,...........25

Tabela 2 - Valores de glicemia para diagnóstico de diabetes melito60................26

Tabela 3- Amostras do complexo európio tetraciclinas........................................31

Tabela 4 - Valores de referência dos componentes inorgânicos estudados......32

Tabela 5 - Deslocamento dos picos de absorção e emissão dos complexos

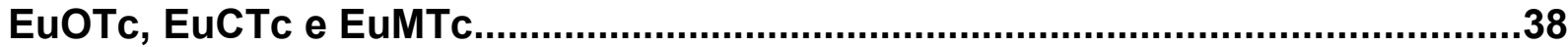

Tabela 6 - Razões molares do EuTC na presença de PH que obtiveram emissão com maior intensidade.

Tabela 7 - Razão molar do EuTC na presença de PHU que obteve emissão com maior intensidade.

Tabela 8 - Razão Molar das amostras de EuTC para estudo de tempo de vida.. 55

Tabela 9 - Parâmetros da dupla exponencial e tempo de vida dos complexos EuTc, EuTc-PH e EuTc-PHU

Tabela 10 - Parâmetros da dupla exponencial e tempo de vida dos complexos EuOTc, EuOTc-PH e EuOTc-PHU.

Tabela 11 - Parâmetros da dupla exponencial e tempo de vida dos complexos EuCTc, EuCTc-PH e EuCTc-PHU. .58

Tabela 12- Parâmetros da dupla exponencial e tempo de vida dos complexos EuMTc, EuMTc-PH e EuMTc-PHU.

Tabela 13 - Parâmetros da dupla exponencial e tempo de vida do complexo EuTc com diferentes concentrações de Glicose acrescidas de Gox....................69

Tabela 14 - Parâmetros da dupla exponencial e tempo de vida do complexo EuCTc com diferentes concentrações de Glicose acrescidas de Gox..................70

Tabela 15 - Parâmetros da dupla exponencial e tempo de vida do complexo EuOTc com diferentes concentrações de Glicose acrescidas de Gox.................71

Tabela 16 - Resumo dos resultados obtidos nos estudos com peróxido de hidrogênio e peróxido de uréia. 


\section{LISTA DE FIGURAS}

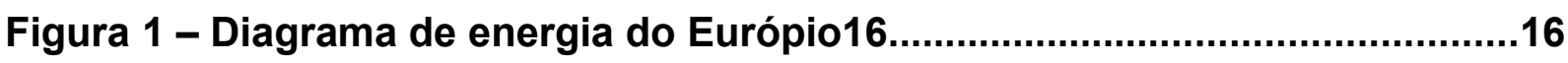

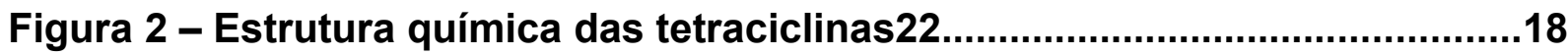

Figura 3 - Mecanismo de emissão de fluorescência de complexos de Eu3+, sendo S0, S1 e T1 estado singleto fundamental, estado singleto excitado, e

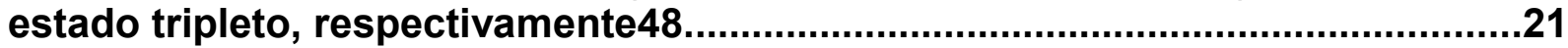

Figura 4 - Proposta de estrutura para o complexo Eu-Tc......................................23

Figura 5 - Espectofotômetro Fluorolog 3.............................................................29

Figura 6 - Estrutura do ácido propanosulfônico 3-(N-morfolino) ou MOPS........34

Figura 7 - Espectro de absorção óptica do tampão MOPS, íon európio em solução MOPS, solução-mãe PH e solução-mãe PHU............................................34

Figura 8 - Espectro de absorção óptica: (a) complexo EuOTc e OTc, (b) complexo EuCTc e CTc, (c) complexo EuMTc e MTc..............................................35

Figura 9 - (a) Espectro de emissão óptica das soluções de OTc e do íon európio. (b) Emissão óptica do complexo EuOTc em diversas razões molares.

Figura 10 - (a) Espectro de emissão óptica da solução CTc. (b) Emissão óptica do complexo EuCTc em diversas razões molares.

Figura 11 - (a) Espectro de emissão óptica da solução MTc. (b) Emissão óptica do complexo EuMTc em diversas razões molares.

Figura 12 - Espectro de absorção óptica dos complexos (a)EuOTc, (b)EuCTc, (c)EuMTc, em diferentes concentrações molares, com e sem PH..

Figura 13 - Espectro de emissão dos complexos: (a) EuOTc-PH, (b) EuCTc-PH, (c) EuMTc-PH, em diferentes concentrações molares EuTC.

Figura 14 - (a) Espectro de emissão (b) e curva de calibração do complexo 3Eu:1Tc-PH.

Figura 15 - (a) Espectro de emissão e (b) curva de calibração complexo 4Eu:1CTc-PH.

Figura 16 - (a) Espectro de emissão e (b) curva de calibração do complexo 4Eu:10Tc-PH.

Figura 17 - (a) Espectro de emissão e (b) curva de calibração do complexo 2Eu:1MTc-PH.

Figura 18 - Espectro de absorção óptica dos complexos (a)EuOTc, (b)EuCTc, (c)EuMTc, em diferentes concentrações molares sem PHU e com PHU. .48

Figura 19 - Espectro de emissão dos complexos (a) EuOTc-PHU, (b) EuCTcPHU, (c) EuMTc-PHU, em diferentes concentrações molares de EuTC. 
Figura 20 - (a) Espectro de emissão e (b) curva de calibração do complexo 3Eu:1Tc-PHU.

Figura 21 - (a) Espectro de emissão e (b) curva de calibração do complexo 4Eu:10Tc-PHU.

Figura 22 - (a) Espectro de emissão e (b) curva de calibração do complexo 3,5Eu:1CTc-PHU.

Figura 23 - (a) Espectro de emissão e (b) curva de calibração do complexo 1,5Eu:1MTc-PHU. .53

Figura 24 - Tempo de vida dos complexos EuTc, EuTc-PH e EuTc-PHU. .56

Figura 25 - Tempo de vida dos complexos EuOTc, EuOTc-PH e EuOTc-PHU....57 Figura 26 - Tempo de vida dos complexos EuCTc, (a) EuCTc-PHU e (b)EuCTcPH. 58

Figura 27 - Tempo de vida dos complexos EuMTc, (a) EuMTc-PH e (b) EuMTcPHU. 59

Figura 28 - Comparação da intensidade de emissão entre o os sinais dos complexos EuTc, EuTc-PH e dos complexos EuTc-PH na presença de interferentes. .61

Figura 29 - Comparação da intensidade de emissão entre o os sinais dos complexos EuOTc, EuOTc-PH e dos complexos EuOTc-PH na presença de interferentes. .61

Figura 30 - Comparação da intensidade de emissão entre o os sinais dos complexos EuCTc, EuCTc-PH e dos complexos EuCTc-PH na presença de interferentes. 62

Figura 31 - Comparação da intensidade de emissão entre o os sinais dos complexos EuTc, EuTc-PHU e dos complexos EuTc-PHU na presença de interferentes. .63

Figura 32 - Comparação da intensidade de emissão entre o os sinais dos complexos EuOTc, EuOTc-PHU e dos complexos EuOTc-PHU na presença de interferentes.

Figura 33 - Comparação da intensidade de emissão entre o os sinais dos complexos EuCTc, EuCTc-PHU e dos complexos EuCTc-PHU na presença de interferentes.

Figura 34 - Emissão dos complexos EuOTc e EuCTc, acrescidos de glicose nas concentrações de 50, 100 e $200 \mathrm{mg} / \mathrm{dL}$

Figura 35 - Emissão e curva de calibração dos complexos EuTc-Glicose-Gox, variando a concentração de glicose nas amostras. Excitação em $400 \mathrm{~nm}$..........66

Figura 36 - Emissão e curva de calibração dos complexos EuOTc-Glicose-Gox, variando a concentração de glicose nas amostras. Excitação em $390 \mathrm{~nm}$.........67

Figura 37 - Emissão e curva de calibração dos complexos EuCTc-Glicose-Gox, variando a concentração de glicose nas amostras. Excitação em $390 \mathrm{~nm}$..........68 
Figura 38 - Tempo de vida do complexo EuTc com diferentes concentrações de

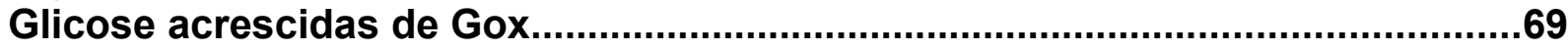

Figura 39 - Tempo de vida do complexo EuCTc com diferentes concentrações de Glicose acrescidas de Gox................................................................................

Figura 40 - Tempo de vida do complexo EuOTc com diferentes concentrações de Glicose acrescidas de Gox............................................................................... 


\section{LISTA DE ABREVIATURAS E/OU SIGLAS}

$\begin{array}{ll}\text { Eu } & \text { Európio } \\ \text { EuCTc } & \text { Complexo Európio-Clorotetraciclina } \\ \text { EuMTc } & \text { Complexo Európio-Metaciclina } \\ \text { EuOTc } & \text { Complexo Európio-Oxitetraciclina } \\ \text { EuTC } & \text { Complexo Európio e um componente da família da Tetraciclina } \\ \text { EuTc } & \text { Complexo Európio-Tetraciclina } \\ \text { Gox } & \text { Glicose Oxidase } \\ \text { MOPS } & \text { Ácido propanosulfônico 3-(N-morfolino) } \\ \text { MTc } & \text { Metaciclina } \\ \text { OTc } & \text { Oxitetraciclina } \\ \text { PH } & \text { Peróxido de Hidrogênio } \\ \text { PHU } & \text { Peróxido de Uréia } \\ \text { pH } & \text { Potencial Higrogeniônico } \\ \text { Tc } & \text { Tetraciclina }\end{array}$




\section{INTRODUÇÃO}

As propriedades ópticas de complexos de íons lantanídeos vem sendo estudadas desde 1941, sendo íon európio um dos lantanídeos de maior interesse1.

A emissão por excitação direta do íon európio é pouco eficiente. Porém quando ligado a outras moléculas, há a formação de um complexo cuja luminescência torna-se mais intensa e a banda de emissão mantém-se bem definida, característica dos íons lantanídeos. Este fenômeno chama-se "efeito antena", onde o ligante absorve a radiação incidente transferindo-a para o íon európio (transferência de energia intramolecular). Como resultado ocorre um aumento da luminescência, grande deslocamento Stokes (ampla banda de absorção, com pico em torno de 400 $\mathrm{nm}$ e emissão em torno de $615 \mathrm{~nm}$ ) e o aumento no tempo de decaimento².

As tetraciclinas são uma família de antibióticos extensivamente utilizados com amplo espectro de ação. São fortes agentes quelantes, complexando-se facilmente com íons metálicos, como o íon európio ${ }^{3}$.

A emissão do complexo európio-tetraciclina (EuTC) é fortemente dependente das características da solução, tais como presença ou ausência de peróxido de hidrogênio e peróxido de uréia.

O peróxido de hidrogênio $(\mathrm{PH})$ é um poderoso oxidante, vastamente utilizado em indústrias especialmente para clareamento, limpeza e desinfecção podendo ser liberado no meio ambiente, logo a importância da sua detecção. Além disso, é produto de diversas reações metabólicas do nosso organismo possibilitando a detecção indireta dos seus produtos ${ }^{4}$. Já o peróxido de uréia é um agente citotóxico e seu aumento no organismo está relacionado à problemas renais 5 .

$\mathrm{Na}$ presença de peróxido de hidrogênio, o complexo EuTC fluorescente, se transforma no complexo EuTC-PH altamente fluorescente. Com adição de pequenas quantidades de peróxido de hidrogênio ocorre um aumento de até 15 vezes na intensidade da banda de emissão do európio em torno de $615 \mathrm{~nm}$, em solução com $\mathrm{pH}$ neutro. $\mathrm{O}$ tempo de vida do európio no complexo EuTC-PH aumenta para $\sim 60$ 
microssegundos decorrente de uma redução da supressão da luminescência por transferência de energia intramolecular ${ }^{6}$. Efeitos semelhantes ocorrem na formação de complexos EuTC com peróxido de uréia ${ }^{7}$.

Tais características proporcionam às medidas de emissão e tempo de vida, alta sensitividade, alta sensibilidade e especificidade na detecção de peróxido de hidrogênio, peróxido de uréia e glicose, esta substrato de reações catalisadas por oxidases produzindo $\mathrm{PH}$. O complexo EuTc é de fácil síntese, opera em $\mathrm{pH}$ neutro, apresenta alta estabilidade e baixo custo. É frequentemente estudado devido ao seu alto potencial em aplicações nas áreas da biomedicina, indústria e meio ambiente6.

Neste trabalho estudamos alguns dos componentes da família da tetraciclina (oxitetraciclina, clorotetraciclina e metaciclina) na formação do complexo com o íon európio, assim como estes complexos em presença do peróxido de hidrogênio e peróxido de uréia. 


\section{OBJETIVOS}

Caracterização e estudo espectroscópico dos complexos európioclorotetraciclina, európio-metaciclina e európio-oxitetraciclina na presença de peróxido de hidrogênio (EuTC-PH) e peróxido de uréia (EuTC-PHU). Obtenção dos espectros de emissão e curvas de tempo de vida do európio em função do aumento de concentração dos peróxidos. Obtenção das curvas de calibração. Estudos de interferentes inorgânicos. Estudo de detecção de glicose. Verificação da

possibilidade de utilização dos complexos como biossensores de peróxido de hidrogênio, peróxido de uréia e glicose. 


\section{REVISÃO DA LITERATURA}

\subsection{Lantanídeos}

A série do lantânio é formada por um conjunto de 15 elementos químicos com números atômicos de 57 (lantânio) ao 71 (lutécio). Os lantanídeos correspondem aos elementos da série que contém elétrons na camada $4 \mathrm{f}$, ou seja, do cério ao lutécio. Juntamente com o escândio $(\mathrm{Sc})$ e ítrio $(\mathrm{Y})$ são conhecidos como terras raras e possuem propriedades físicas e químicas muito semelhantes. Apesar da denominação "raras", estes elementos não são incomuns, exceto pelo promécio que não ocorre na natureza. O túlio que é o elemento menos abundante na crosta terrestre é encontrado mais facilmente que a prata, arsênio, mercúrio, cádmio e selênio8 ${ }^{9}$.

A aplicação dos lantanídeos se estende a diversas áreas, como por exemplo, na fabricação de laser, em reações de catálise e como materiais luminescentes. Também são muito estudados em sistemas biológicos devido às suas propriedades espectroscópicas e magnéticas, sendo utilizados como traçadores biológicos e agentes de contraste em RMN (ressonância magnética nuclear) ${ }^{8,9}$.

A semelhança das propriedades químicas e físicas dos lantanídeos decorre da sua configuração eletrônica. Todos os átomos neutros derivam da configuração do gás nobre xenônio (Xe) seguida do preenchimento sequencial da camada 4f. Assim, os lantanídeos possuem o orbital $6 s^{2}$ e um preenchimento do nível $4 f$ variável apresentando a seguinte distribuição eletrônica: [Xe] $6 s^{2} 4 f^{n} 5 d^{0-1}$, com $n$ variando de 1 até 14 . A camada $4 \mathrm{f}$ é interna, sendo blindada pelas camadas mais externas $6 \mathrm{~s}$ e $5 d^{10}$.

Os íons lantanídeos mais estáveis encontram-se no estado trivalente (3+). Neste caso há a perda de 2 dos elétrons $6 \mathrm{~s}$ e o elétron $5 \mathrm{~d}$ (ou um elétron $4 \mathrm{f}$ caso não exista elétron $5 \mathrm{~d}$ ), e a camada $4 \mathrm{f}$ permanece blindada pelos orbitais $5 \mathrm{p}$ e $5 \mathrm{~s}$. 
Nos compostos com estes íons trivalentes a luminescência em geral, é devida às transições $\mathrm{f}$-f. Os elétrons $4 \mathrm{f}$ são internos sendo fracamente afetados pelo campo dos ligantes, as propriedades eletrônicas são pouco afetadas pelo ambiente químico e assim as transições ópticas são geralmente muito finas. Essas transições $f$ - $f$ são proibidas (regra de Laporte) resultando em baixo coeficiente de absorção e taxa de emissão, logo, suas transições ópticas são geralmente caracterizadas por bandas finas de emissão e tempos de vida longos, de microssegundos a milissegundos. A variação do ambiente do íon apenas causa pequenos desdobramentos nos níveis de energia e nas intensidades relativas das bandas ${ }^{11,12}$. Outro fator interessante é o grande deslocamento Stokes (deslocamento entre comprimento de onda de excitação e emissão) $)^{13}$.

O espectro de emissão dos lantanídeos trivalentes ocorre nas regiões do visível e infravermelho próximo. Por exemplo, o íon európio trivalente é um forte emissor em aproximadamente $615 \mathrm{~nm}$ na região do vermelho e o térbio trivalente emite na região do verde. Em nossos estudos o íon európio foi o lantanídeo escolhido.

\subsection{Európio}

O európio é um elemento químico de símbolo Eu, número atômico 63 e peso atômico 151,96 g. Juntamente com o térbio é dos lantanídeos que possuem maior capacidade de emissão, por isso as propriedades do íon európio são muito estudadas $^{14}$.

Os níveis envolvidos nas transições radiativas são não-degenerados ${ }^{15}$. 0 estado emissivo de energia mais baixo, ${ }^{5} \mathrm{D}_{0}$, é $17.250 \mathrm{~cm}^{-1}$ acima do estado fundamental ${ }^{16}$ (Figura 1). 


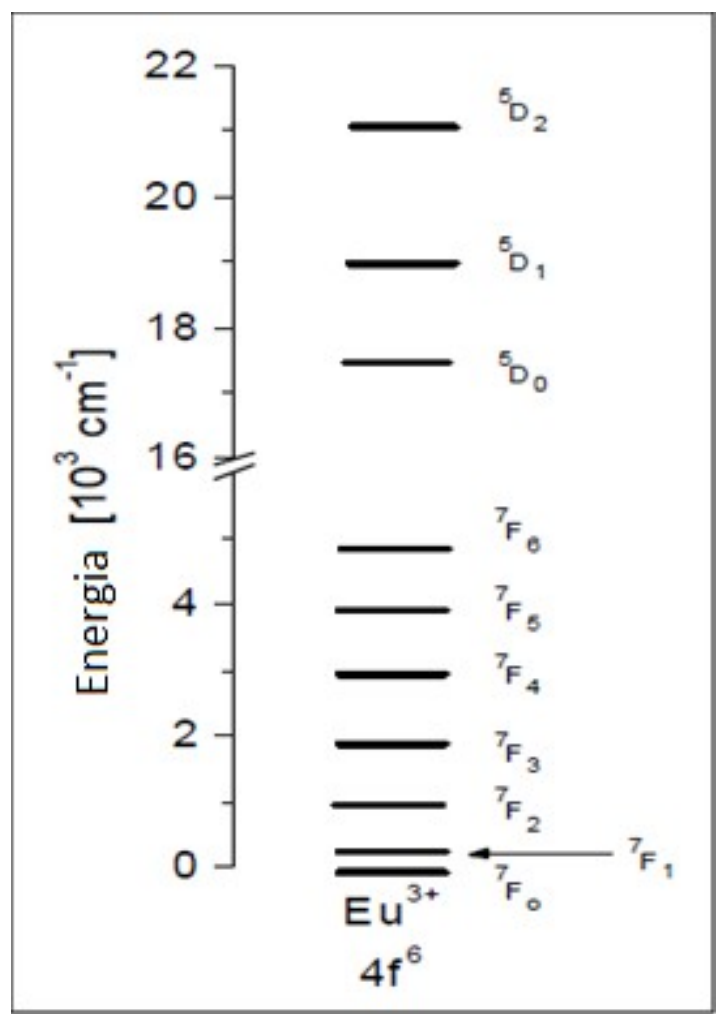

Figura 1 - Diagrama de energia do Európio16.

A luminescência por excitação direta do íon európio é pouco eficiente, pois não têm absortividade molar alta. Porém, quando ligado a outras moléculas formando um complexo, a luminescência torna-se forte e apresenta uma banda de emissão bem definida, característica dos íons lantanídeos.

Um complexo ou composto de coordenação é formado quando um íon metálico central se combina com um grupo de moléculas vizinhas doadoras de um par de elétrons que são compartilhados entre ambas as espécies químicas. As moléculas que circundam o íon metálico são chamadas de ligantes e a quantidade de átomos ligados diretamente ao íon central é denominada número de coordenação. Nos casos em que um cátion metálico liga-se a uma molécula com duas ou mais ligações coordenadas o complexo resultante é chamado de quelato e o ligante referido como agente quelante ou ligante polivalente ${ }^{17}$.

Desta forma, usa-se um agente quelante para absorver a luz transferindo esta energia para o íon lantanídeo, que emite de acordo com sua luminescência 
característica8. Este processo de transferência de energia intramolecular entre o ligante orgânico e o íon lantanídeo é conhecido como efeito antena12,18.

A intensidade da luminescência dos íons lantanídeos é principalmente influenciada pela desativação não-radiativa (supressão) do estado excitado do lantanídeo e da capacidade do estado excitado tripleto do ligante transferir a energia ao nível de emissão do lantanídeo. Fatores estes que dependem da natureza do ligante e íon assim como do meio em que se encontram ${ }^{19}$.

Quando em solução, a emissão do európio pode ser inibida por grupos $\mathrm{OH}, \mathrm{NH}$ e $\mathrm{CH}$. O íon európio apresenta de 8 a 9 sítios de coordenação. O encapsulamento dos íons por agentes quelantes pode aumentar a luminescência e tempo de vida do complexo15,20.

A luminescência e tempo de vida destes complexos em solução está diretamente relacionada com o número de moléculas de água coordenadas ao íon metálico. Devido à eficiente transferência de energia entre o nível de ressonância do ín e o grupo $\mathrm{OH}$, o tempo de vida decresce linearmente conforme o aumento da quantidade de moléculas de água coordenadas3.

Em nosso trabalho utilizaremos como ligantes a oxitetraciclina, clorotetraciclina e metaciclina (compostos da família da tetraciclina) por serem fortes agentes quelantes22. 


\subsection{Tetraciclina}

As tetraciclinas (TCs) são uma família de antibióticos descoberta no final dos anos 40. Sua estrutura básica consiste em um núcleo hidronaftaceno com 4 anéis fundidos3 (Figura 2).

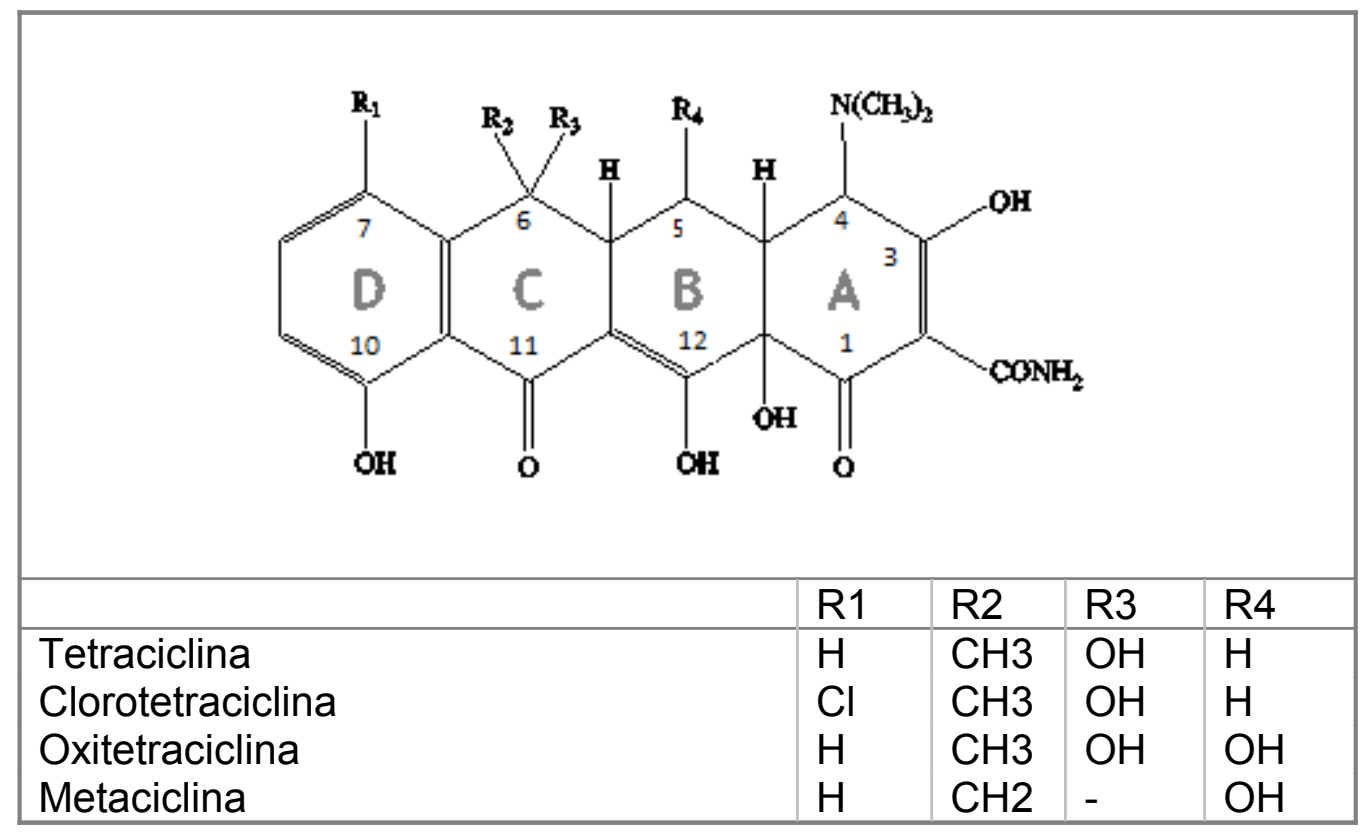

Figura 2 - Estrutura química das tetraciclinas22.

Possuem ação bacteriostática em concentrações terapêuticas e amplo espectro de atividade incluindo bactérias aeróbias e anaeróbias, Gram-positivas, Gram-negativas, espiroquetas, micoplasmas, riquétsias, clamídias e alguns protozoários. Atuam inibindo a síntese protéica bacteriana devido à sua capacidade de ligação aos ribossomos microbianos impedindo a ligação da aminoacil-tRNA aos $\operatorname{mesmos}^{21,22}$.

Devido ao relativo baixo custo e segurança do ponto de vista terapêutico, as tetraciclinas são extensivamente utilizadas em terapias de infecções bacterianas humanas e medicina veterinária, assim como em criadouros de animais para produção de carne, peixes e laticínios ${ }^{23}$. 
Os principais eventos adversos consistem em fototoxicidade, distúrbios gastrointestinais, reações alérgicas em indivíduos mais sensíveis, e, por serem agentes quelantes, as tetraciclinas podem se fixar ao cálcio depositando-se nos ossos e dentes em formação, provocando manchas e, em casos mais graves, hipoplasia dentária e deformidades ósseas. O uso irracional de antibióticos assim como o seu consumo em alimentos em baixas doses por um longo período de tempo pode promover e disseminar a resistência bacteriana. Assim os resíduos destes medicamentos, tetraciclinas inclusive, são rotineiramente monitorados ${ }^{24,25}$.

As tetraciclinas possuem vários possíveis locais de ligação, logo, formam facilmente complexos metálicos, sendo seu mecanismo de ação nos fluidos biológicos fortemente dependente da presença de íons metálicos ${ }^{26}$. Os sítios de complexação incluem o sistema beta-dicetona (posições 11 e 12), os grupos enol (posições 1 e 3) e carboxiamida (posição 2)22.

Em nossos estudos, comparamos a oxitetraciclina, clorotetraciclina e metaciclina com a tetraciclina na formação dos complexos na presença de peróxido de hidrogênio e peróxido de uréia. Espera-se observar variação da emissão do európio, com a mudança estrutural, na formação de complexos. Isto porque a variação da estrutura acarreta em mudança de sítios de ocupação do európio. Em solução aquosa as possíveis ligações do íon európio ocorrem nos radicais $\mathrm{OH}$ dos anéis $\mathrm{B}$ e $\mathrm{A}$ e no nitrogênio do grupo $\mathrm{CH} 3$ do anel $\mathrm{A}$. A diferença entre a tetraciclina e a oxitetraciclina está no radical $\mathrm{R} 4$ que é um $\mathrm{H}$ no caso da tetraciclina e um $\mathrm{OH}$ no caso da oxitetraciclina. No caso da clorotetraciclina o radical R1 é substituído por cloro. Já na metaciclina não existe o grupo $\mathrm{OH}$ no radical R3.

\subsection{Complexo EuTC}

As características espectroscópicas de complexos formados pelo ín európio trivalente com ligantes orgânicos são estudadas desde 19411. Desde então já era 
observada a importante propriedade destes complexos em absorver radiação próximo ao ultravioleta através do ligante orgânico, a transmissão desta energia para o európio (chamada transferência de energia intramolecular) com emissão característica do lantanídeo.

Em 1961 foi proposto que este fenômeno ocorre devido ao aumento da população do estado vibracional do quelato, transferência de energia do estado tripleto para o nível $4 \mathrm{f}$ de menor energia do íon e transição radioativa para o estado fundamental resultando em uma banda de emissão bem delimitada ${ }^{27,28}$.

Em 1982 Richardson ${ }^{29}$ observou experimentalmente as propriedades espectroscópicas do íon európio trivalente concluindo que o íon metálico possuía boas características para ser utilizado como biossensor. Através da complexação do európio com um ligante orgânico observou a transferência de energia do ligante para o európio (transferência intramolecular) com aumento da luminescência.

No ano seguinte Hirschy e colegas $2^{30}$ estudaram a formação do complexo Európio-Tetraciclina (EuTc). Enquanto o complexo apresentava um amplo espectro de absorção, similar ao do ligante orgânico, o espectro de emissão era formado por uma banda estreita e bem definida, característica das transições $4 f$ dos íons lantanídeos, com aumento da luminescência e tempo de vida.

Assim, no quelato a energia é absorvida através da tetraciclina e é transferida através de um efeito antena para o íon európio, que emite parte desta energia em uma banda característica do lantanídeo ${ }^{31}$. Os mecanismos de fluorescência do complexo EuTc são o resultado de diversos processos como mostrado na Figura 3 (diagrama de Jablonski). 


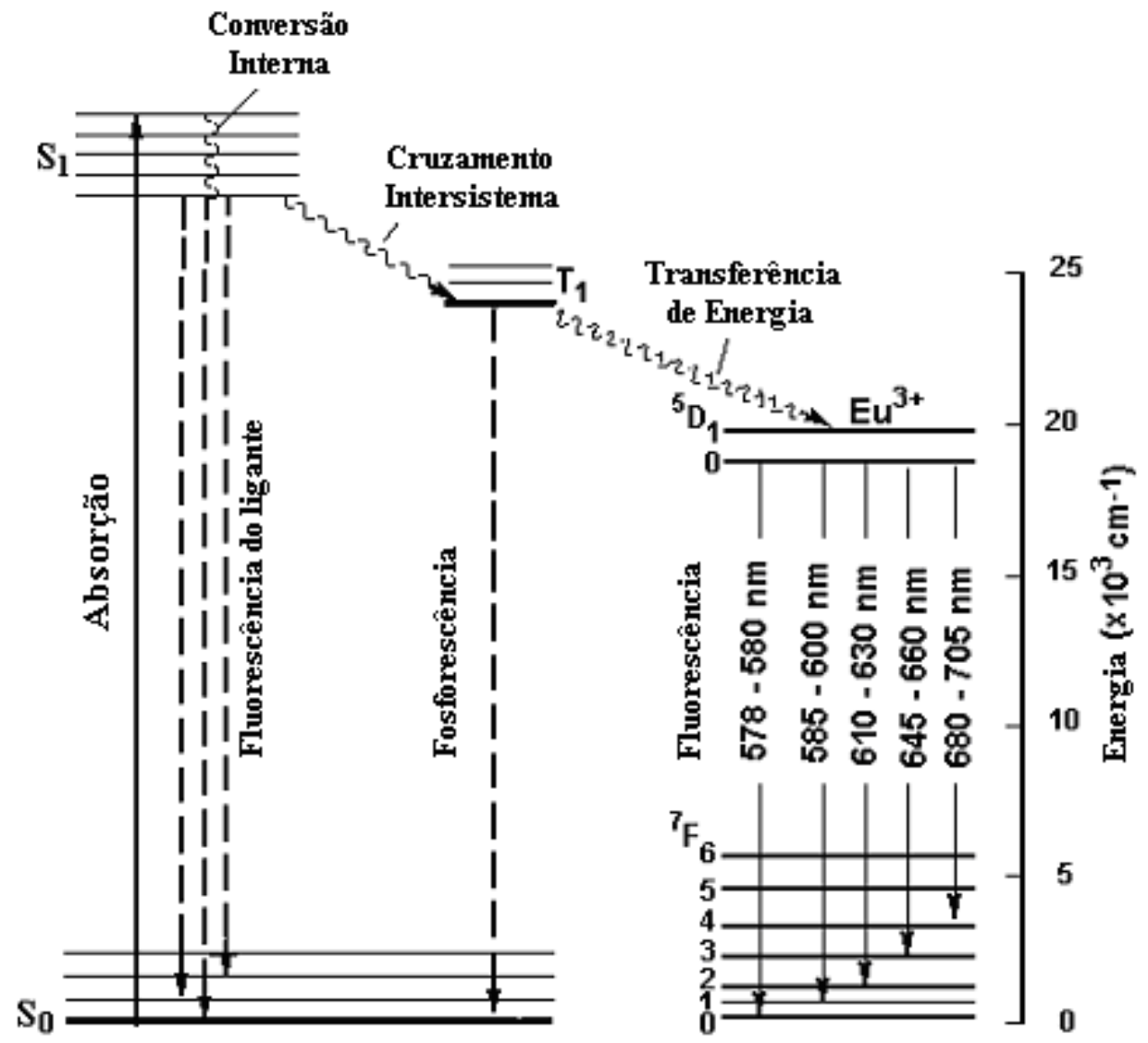

Figura 3 - Mecanismo de emissão de fluorescência de complexos de $\mathrm{Eu}^{3+}$, sendo $\mathrm{S}_{0}$, $\mathrm{S}_{1}$ e $\mathrm{T}_{1}$ estado singleto fundamental, estado singleto excitado, e estado tripleto, respectivamente48.

$\mathrm{Na}$ excitação, a tetraciclina absorve a energia fornecida por uma fonte externa e é elevada do estado singleto fundamental $\left(S_{0}\right)$ para qualquer um dos estados vibracionais do primeiro estado singleto excitado $\left(S_{1}\right)$. Em muitos casos há um relaxamento para o estado vibracional $S_{1}$ de menor energia por conversão interna, um decaimento não radioativo. Novamente, através de um processo não radiativo de cruzamento intersistema (ISC - intersystem crossing), ocorre o decaimento de $S_{1}$ para o primeiro estado tripleto $T_{1}$. Então ocorre a transferência de energia intramolecular do estado tripleto do ligante orgânico para o íon európio trivalente, com nível de energia mais baixo que o nível $\mathrm{T}_{1}$. Assim o $\mathrm{Eu}^{3+}$ é excitado, de onde partem múltiplas emissões provenientes das transições eletrônicas ${ }^{5} D_{0} \rightarrow{ }^{7} F_{J}(J=0$, 
$1,2,3,4)$ e ${ }^{5} D_{1} \rightarrow{ }^{7} F_{J}(J=1,2,3,5,6)$. As transições mais intensas são ${ }^{5} D_{0} \rightarrow{ }^{7} F_{2} e$ ${ }^{5} \mathrm{D}_{0} \rightarrow{ }^{7} \mathrm{~F}_{1}$ em torno de $610-660 \mathrm{~nm}$ e $585-600 \mathrm{~nm}$, respectivamente ${ }^{32,33}$.

Devido à dissipação de energia durante os processos de conversão interna, conversão intersistema e transferência de energia intramolecular a energia emitida pelo lantanídeo é muito diferente da energia de excitação. Assim, há um grande deslocamento entre os espectros de absorção e emissão (deslocamento Stokes). No complexo EuTc o deslocamento é de aproximadamente $220 \mathrm{~nm}$ (absorção 395 nm e emissão $\sim 615 \mathrm{~nm}$ ), característica que pode ser aplicada para evitar a sobreposição entre os espectros de excitação e de emissão do próprio fluoróforo ou a emissão da matriz biológica.

Outra propriedade interessante é a estreita banda de emissão. Isso acontece por causa da proteção ou blindagem dos orbitais $f$ pelos orbitais mais elevados $s$ e $p$ do lantanídeo. E a intensidade de fluorescência da banda principal do complexo de lantanídeo é muito alta, embora seu rendimento quântico seja geralmente mais baixo do que aquele dos fluoróforos convencionais. A razão disso é que a energia transferida é fortemente emitida por uma banda estreita48.

Além disso, o complexo possui um longo tempo de vida da fluorescência ( 20 $\mu \mathrm{s})$. As transições eletrônicas f-f do lantanídeo são proibidas, conduzindo para longo tempo de vida do estado excitado ${ }^{34}$. Os tempos de decaimento de complexos de lantanídeo são completamente sensíveis à natureza detalhada do ambiente do ligante, em especial ao número de moléculas de água que ocupam locais internos da coordenação. As transições proibidas f-f são refletidas também nos coeficientes baixos de excitação, o que dificulta a foto-excitação direta de seus íons, e requerendo desta forma a presença de ligantes orgânicos para a absorção da energia ${ }^{35}$. Os tempos de decaimentos relativamente longos de complexos de lantanídeos facilitam a fluorometria resolvida no tempo.

Devido às propriedades citadas, existem diversas aplicações deste complexo desde a detecção de teores da própria tetraciclina ${ }^{36,37}$, até detecção de peróxido de hidrogênio6, glicose ${ }^{38}$, heparina ${ }^{39}$, peróxido de uréia ${ }^{40}$, etc. 
Na Figura 4 é apresentada uma proposta da estrutura para o complexo Eu-Tc em $\mathrm{pH}$ neutro.

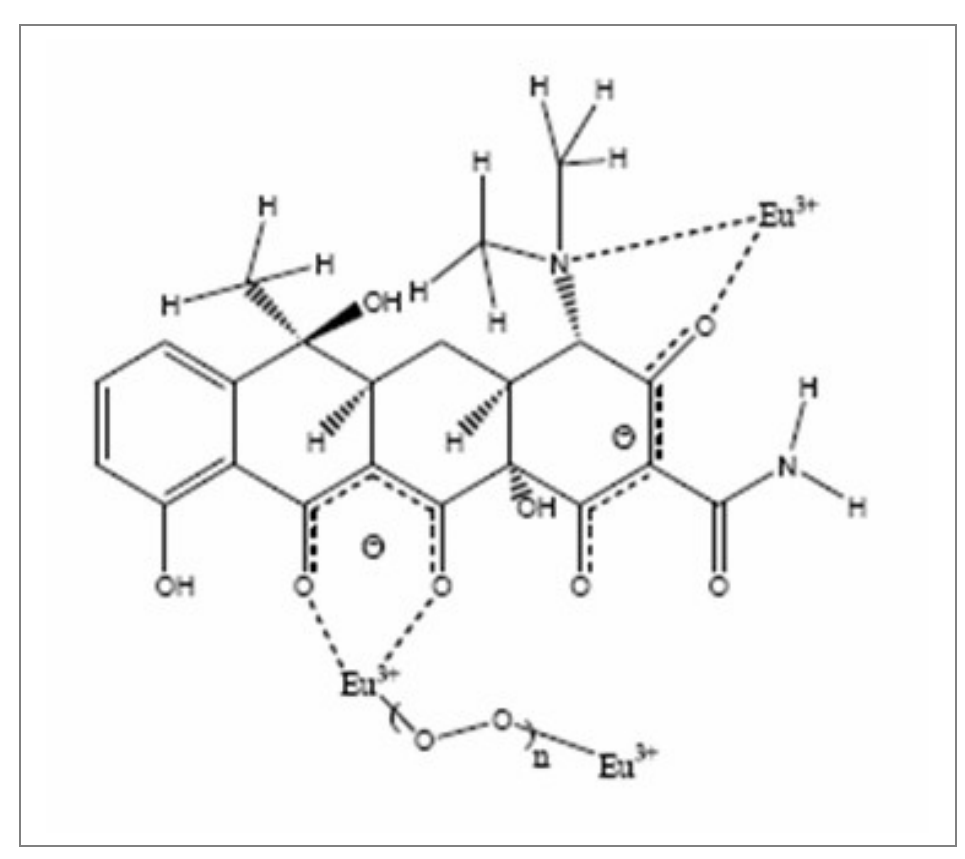

Figura 4 - Proposta de estrutura para o complexo Eu-Tc.

\subsection{Peróxido de Hidrogênio}

O peróxido de hidrogênio $(\mathrm{PH})$, de fórmula molecular $\mathrm{H}_{2} \mathrm{O}_{2}$ e comercialmente conhecido como água oxigenada, é um potente agente oxidante o qual pode ser convertido, através de catálise, em radical hidroxila $(\cdot \mathrm{OH})$ com reatividade inferior apenas ao flúor. É um líquido transparente, assemelhando-se à água e tem odor característico. Não é inflamável, é miscível em água em todas as proporções4.

É formado pela ação da luz solar na água em presença de substâncias húmicas (material orgânico dissolvido) ${ }^{41,42}$.

O peróxido de hidrogênio está presente em pequenas concentrações na atmosfera e no ambiente marinho ${ }^{43}$. $\mathrm{Na}$ atmosfera, $\mathrm{O}_{2} \mathrm{O}_{2}$ contribui diretamente como agente oxidante para a conversão de $\mathrm{SO}_{2}$ em $\mathrm{H}_{2} \mathrm{SO}_{4}$ - um dos maiores responsáveis pela chuva ácida - e indiretamente pela formação de radicais hidroxila, que reagem com milhares de gases atmosféricos, podendo causar danos à camada 
de ozônio ${ }^{44,45}$. É um composto amplamente utilizado na indústria para branqueamento, limpeza e desinfecção, sendo liberado ao meio ambiente em grandes quantidades, logo a relevância de seu monitoramento ambiental ${ }^{46}$. Também é importante em áreas envolvendo medicamentos e alimentos4.

$\mathrm{O} \mathrm{PH}$ é um metabólito natural de muitos organismos sendo decomposto em oxigênio molecular e água e está presente em inúmeras reações biológicas como principal produto de oxidases.

Assim, diversas substâncias de grande importância no nosso organismo como, por exemplo, o álcool ${ }^{47}$, a glicose $e^{48}$, lactose ${ }^{49}$ e até a atividade da catalase $e^{50,51}$ podem ser determinadas indiretamente através da detecção do peróxido de hidrogênio resultante das reações de oxidação.

$\mathrm{Na}$ presença de peróxido de hidrogênio, o complexo európio-tetraciclina (EuTc) fracamente fluorescente, se transforma no complexo (EuTc-PH) que é altamente fluorescente. Este processo foi observado por Y. Rakicioglu em 199952, e aplicado por A. Duerkop na detecção de peróxido de hidrogênio em águas de rios ${ }^{53}$.

Com adição de pequenas quantidades de peróxido de hidrogênio ocorre um aumento de até 15 vezes da intensidade da banda de emissão do európio em torno de $615 \mathrm{~nm}$ em solução com pH neutro. Este aumento ocorre devido à formação de um novo complexo, onde moléculas de água circundantes ao íon európio são substituídas por peróxido de hidrogênio, minimizando efeitos de supressão. O tempo de vida do európio no complexo EuTc-PH aumenta de $\sim 20 \mu$ s para $\sim 60 \mu$ s.

A Tabela 1 compara o método de determinação de $\mathrm{PH}$ utilizando a sonda európio-tetraciclina com outros métodos utilizados. Desta forma, tanto a espectroscopia de emissão como a espectroscopia resolvida no tempo são técnicas sensíveis a presença de peróxido de hidrogênio em solução. 
Tabela 1 - Métodos para determinação de peróxido de hidrogênio4,52,54.

\begin{tabular}{lll}
\hline \multicolumn{1}{c}{ Método } & \multicolumn{1}{c}{$\begin{array}{c}\text { Escala } \\
\text { Linear }\end{array}$} & \multicolumn{1}{c}{$\begin{array}{c}\text { Limite de } \\
\text { Detecção }\end{array}$} \\
\hline Eletrodo modificado (carbono vítreo) & $5-50 \mu \mathrm{mol} . \mathrm{L}^{-1}$ & $0,5 \mu \mathrm{mol} . \mathrm{L}^{-1}$ \\
Biossensor Amperométrico (carbono vítreo) & $0,01-1,5 \mathrm{mmol} . \mathrm{L}^{-1}$ & $5 \mu \mathrm{mol} . \mathrm{L}^{-1}$ \\
Biossensor Potenciométrico (eletrodo redox) & $1,98-9,86 \mathrm{~mol} . \mathrm{L}^{-1}$ & $0,4 \mu \mathrm{mol} . \mathrm{L}^{-1}$ \\
Biossensor Condutométrico (ouro) & $5-300 \mu \mathrm{mol} . \mathrm{L}^{-1}$ & - \\
Biossensor de Fibra Óptica & $0,05-1,2 \mathrm{mmol} . \mathrm{L}^{-1}$ & $25 \mu \mathrm{mol} . \mathrm{L}^{-1}$ \\
Quimiluminescência (Luminol e Peroxidase) & $0,1-0,3 \mathrm{mmol} . \mathrm{L}^{-1}$ & $0,67 \mathrm{mmol} . \mathrm{L}^{-1}$ \\
UV-Vis (Ferro e Porfirina) & $3,5-70 \mu \mathrm{mol} . \mathrm{L}^{-1}$ & $1 \mu \mathrm{mol} . \mathrm{L}^{-1}$ \\
Volumetria & $41-200 \mu \mathrm{mol} . \mathrm{L}^{-1}$ & $3 \mu \mathrm{mol} . \mathrm{L}^{-1}$ \\
Cromatografia Líquida & $0,5-5 \mu \mathrm{mol} . \mathrm{L}^{-1}$ & $0,15 \mu \mathrm{mol} . \mathrm{L}^{-1}$ \\
EuTc & $2-400 \mu \mathrm{mol} . \mathrm{L}^{-1}$ & $0,96 \mu \mathrm{mol} . \mathrm{L}^{-1}$ \\
\hline
\end{tabular}

\subsection{Peróxido de Uréia}

O peróxido de uréia (PHU), ou peróxido de carbamida, possui a fórmula molecular $\mathrm{CH}_{4} \mathrm{~N}_{2} \mathrm{O} \cdot \mathrm{H}_{2} \mathrm{O}_{2}$, ou seja, é formado por uma molécula de uréia ligada ao peróxido de hidrogênio, sendo uma forma estável do $\mathrm{H}_{2} \mathrm{O}_{2}$. O PHU é um forte agente oxidante e apresenta efeito citotóxico5, ${ }^{55}$.

A uréia é a principal forma de excreção de nitrogênio realizada pelos rins em nosso organismo em um processo metabólico chamado ciclo da uréia. A fim de serem utilizados pelo nosso organismo, os aminoácidos sofrem um processo de desaminação (remoção do grupo amina) produzindo amônia $\left(\mathrm{NH}_{3}\right)$. Estas moléculas capturam íons de hidrogênio transformando-se em amônio $\left(\mathrm{NH}_{4}^{+}\right)$. Ambos, amônia e amônio, são tóxicos e, portanto convertidos no fígado em uréia sendo finalmente excretadas pelos rins ${ }^{56}$.

Indivíduos com insuficiência renal crônica apresentam elevação nos níveis de PHU. Experimentos mostram que os níveis de pentosidina e carboximetillisina foram aumentados pelo radical hidroxila gerado pelo PHU através da reação de Fenton. As substâncias citadas (pentosidina e carboximetillisina) são produtos da reação de 
Maillard, e podem promover várias respostas celulares, resultando em disfunções vasculares, aterosclerose, piora do quadro de diabetes e envelhecimento celular ${ }^{57,58}$.

A determinação de $\mathrm{PHU}$ é realizada por meio de métodos indiretos com diversas etapas e reagentes57. O complexo európio-tetraciclina utilizado como sensor de PHU pode ser uma alternativa mais econômica e direta $40^{7}$.

\subsection{Glicose}

A glicose ou dextrose é um monossacarídeo, o menor tipo de carboidrato. Todas as células dos organismos vivos armazenam glicose como fonte de energia na forma de polissacarídeo (moléculas complexas de carboidratos)56.

O aumento da concentração de glicose no sangue, ou hiperglicemia, é resultante de alterações da secreção de insulina e/ou ação da insulina nos tecidos. $O$ conjunto de disfunções metabólicas causado pelo aumento da glicemia chama-se diabetes melito, e tem como sintomas clássicos poliúria (aumento do volume de urina), polidispia (sede), perda de peso, visão embaçada e fadiga. Tem como complicações crônicas retinopatia, aumento do risco de infecções e nefropatia, esta provocando disfunções gastrointestinais, cardiovasculares e sexuais ${ }^{59,60}$.

Cerca de $7,6 \%$ da população adulta entre 30 e 69 anos e 0,3\% das gestantes sofrem de diabetes. Alterações da tolerância à glicose são observadas em $12 \%$ dos adultos e em $7 \%$ das grávidas, e apenas aproximadamente $50 \%$ dos indivíduos acometidos pela doença tem conhecimento do diagnóstico ${ }^{61}$.

O diagnóstico do diabetes baseia-se fundamentalmente nas alterações da glicose plasmática de jejum ou após uma sobrecarga de glicose por via oral 61.

A concentração de glicose sanguínea varia normalmente de 80 a $120 \mathrm{mg} / \mathrm{dL}$. A Tabela 2 mostra os valores da glicemia considerados normais e que diagnostica o diabetes pelo comitê especialista internacional de diabetes, financiado pela Sociedade Americana de Diabetes e aceito pela Organização Mundial de Saúde60.

Tabela 2 - Valores de glicemia para diagnóstico de diabetes melito60

\begin{tabular}{|c|c|c|c|}
\hline Diagnóstico & $\begin{array}{c}\text { Glicemia em } \\
\text { jejum }(\mathrm{mg} / \mathrm{dL})\end{array}$ & $\begin{array}{c}\text { Glicemia } 2 \mathrm{~h} \text { após } \\
\text { a ingestão de } 75 \mathrm{~g} \\
\text { glicose }(\mathrm{mg} / \mathrm{dL})\end{array}$ & $\begin{array}{c}\text { Glicemia casual- } \\
\text { horário aleatório } \\
(\mathrm{mg} / \mathrm{dL})\end{array}$ \\
\hline
\end{tabular}




\begin{tabular}{|l|c|c|l|}
\hline Normal & $<100$ & $<140$ & \\
\hline $\begin{array}{l}\text { Tolerância à } \\
\text { glicose diminuída }\end{array}$ & $\geq 100 \mathrm{a}<126$ & $\geq 140 \mathrm{a}<200$ & \\
\hline Diabetes mellitus & $\geq 126$ & $\geq 200$ & $\begin{array}{l}\geq 200 \text { (com } \\
\text { sintomas clássicos) }\end{array}$ \\
\hline
\end{tabular}

Existem 3 principais métodos laboratoriais para determinação da glicose no sangue: métodos de redução e de condensação (ambos métodos químicos) e métodos enzimáticos.

Dos métodos químicos empregados, os de redução são os mais antigos e baseiam-se nas propriedades de redução da glicose. Os oxidantes utilizados são o cobre ou o íon ferricianeto em meio alcalino, reduzidos pela glicose a íon cuproso e ín ferrocianeto, respectivamente. Os métodos mais populares transformam os íons cuprosos a óxido cuproso em presença de calor. A coloração é feita através da redução do fosfomolibdato (Folin-Wu) ou arsenomolibdato (Somogyi-Nelson) para formar azul de molibdênio. Estes métodos são não-específicos e qualquer agente redutor forte pode elevar o valor real do resultado ${ }^{62,63}$.

Nos métodos de condensação o grupo aldeído da glicose reage com aminas aromáticas formando um produto colorido, cuja intensidade é medida através de espectrofotometria no UV-visível e relacionada com a concentração de glicose. Um exemplo clássico é a reação da o-toluidina com a glicose em ácido acético formando uma glicosilamina com intensa colocação verde cuja absorbância é medida em 630 $\mathrm{nm}$. Uma desvantagem é a alta corrosividade e toxicidade da o-toluidina. Além disso, o método sofre interferências podendo causar resultados falsamente elevados como, por exemplo, em amostras com teores elevados de bilirrubina que pode ser parcialmente transformada em biliverdina de cor verde, ou turvação na solução final como em presença de lipemia (aumento na concentração de lipídeos no sangue), condição frequentemente encontrada em diabéticos $62^{63}$.

Os métodos químicos (de redução e condensação) citados acima estão em desuso por não apresentarem a especificidade adequada, sendo os métodos enzimáticos preferidos para diagnóstico, pois são absolutamente específicos para glicose e mais simples de serem realizados61. 
Métodos enzimáticos utilizam enzimas como reativos. As principais enzimas utilizadas são: glicose desidrogenase, hexoquinase e glicose oxidase.

A glicose desidrogenase catalisa a redução de $\mathrm{NAD}^{+}$, produzindo gliconolactona e NADH que pode ser monitorado em $340 \mathrm{~nm}$. O método com a enzima hexoquinase é realizado em duas etapas. Primeiramente a glicose é fosforilada pelo ATP com a ação da hexoquinase formando glicose-6-fosfato. $\mathrm{Na}$ segunda etapa a glicose-6-fosfato é convertida por outra enzima, a glicose-6-fosfato desidrogenase, na presença de $\mathrm{NADP}^{+}$, em 6-fosfogliconolactona e NADPH. Finalmente o NADPH formado é proporcional à quantidade de glicose na amostra e é medido em $340 \mathrm{~nm}$, como no método enzimático da glicose desidrogenase62,63.

$O$ método com a glicose-oxidase ou Gox é específico para a $\beta$-D-Glicose. Em solução, aproximadamente $66 \%$ da D-glicose encontra-se no estado $\beta$ e $34 \%$ na forma de $\alpha$-D-Glicose 62. Primeiramente a Gox catalisa a oxidação da glicose para ácido glicônico e peróxido de hidrogênio de acordo com a reação abaixo 48:

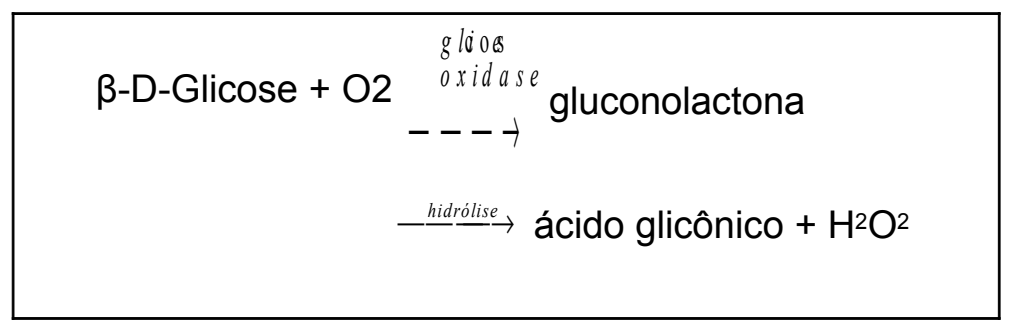

A quantidade de peróxido formada na reação é então mensurada de diversas formas. Usualmente utiliza-se novamente a enzima peroxidase que oxida o $\mathrm{H}_{2} \mathrm{O}_{2} \mathrm{em}$ um cromogênio para formar um complexo oxidado colorido que revela a presença de glicose (método enzimático-colorimétrico).

Outra forma que está sendo estudada atualmente é utilizar o complexo EuTC, que reage com $\circ \mathrm{H}_{2} \mathrm{O}_{2}$ formando um complexo altamente fluorescente cuja intensidade é medida através de espectrofotometria em $615 \mathrm{~nm} 48$. Através deste método não há a necessidade de utilizar outra enzima e é possível observar a emissão em um comprimento de onda na região visível. 


\section{MATERIAIS E MÉTODOS}

Os equipamentos utilizados para a realização das medidas encontram-se no Centro de Lasers e Aplicações (CLA) do Instituto de Pesquisas Energéticas e Nucleares (IPEN)/USP. Todos os experimentos foram realizados em temperatura ambiente.

Os espectros de absorção das amostras foram medidos em um espectrofotômetro Cary-Olis-17D. Para a obtenção dos espectros de emissão e tempo de vida utilizamos o sistema Fluorolog 3 da Jobin Yvon (Figura 5). O fluorímetro fornece uma curva de contagens de fótons em função do comprimento de onda.

$\mathrm{Em}$ todas as medidas realizadas neste aparelho as amostras foram colocadas em cubetas com as quatro faces polidas, com $1 \mathrm{~mm}$ de caminho óptico.

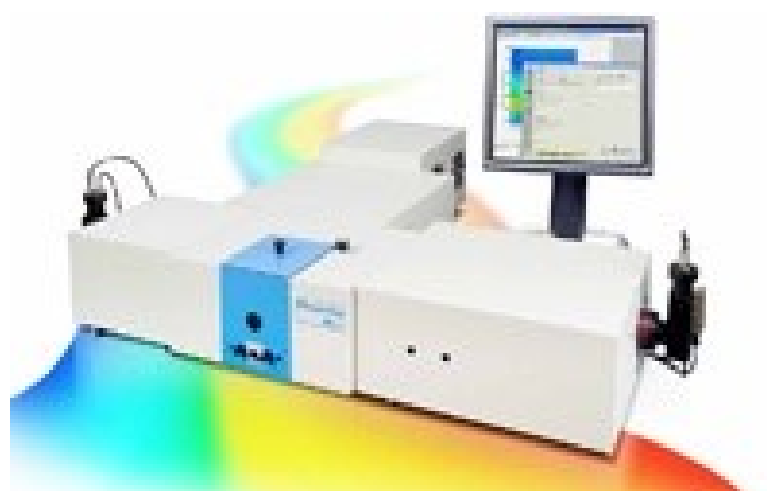

Figura 5 - Espectofotômetro Fluorolog 3.

Dados técnicos do Fluorolog 3:

- Excitação: Lâmpada de Xe 450 Watts;

- Acurácia: $0.5 \mathrm{~nm}$; 
- Velocidade: $150 \mathrm{~nm} / \mathrm{s}$;

- Faixa de deteç̧ão: $0 \mathrm{~nm}-1100 \mathrm{~nm}$;

- Grades: 330 nm (intervalo de 200-700 nm) e 500 nm (intervalo de 300-1000 $\mathrm{nm})$;

- Sensibilidade: $\mathrm{S} / \mathrm{N}>5000: 1$ (R928 PMT) em $397 \mathrm{~nm}$, com slits de $5 \mathrm{~nm}$;

- Tempo de pulso: $10 \mu \mathrm{s}$.

\subsection{Reagentes e Solventes}

Os reagentes e solventes utilizados seguem listados abaixo:

- Cloreto de Európio Hexahidratado

- Cloridrato de Tetraciclina

- Cloridrato de Clorotetraciclina

- Cloridrato de Oxitetraciclina

- Cloridrato de Metaciclina

- Água bideionizada

- Hidróxido de sódio

- Ácido propanosulfônico 3-(N-morfolino) ou MOPS

- Peróxido de Hidrogênio

- Peróxido de Uréia

- Glicose Oxidase

As tetraciclinas foram importadas da Sigma Aldrich, cloreto de európio hexa-hidratado da Molecular Probe, solução tampão MOPS da alemã Carl Roth. A glicose oxidase foi adquirida do kit comercial de dosagem de glicose por método enzimático Laborlab. Usou-se a glicose anidra e peróxido de hidrogênio $30 \%$ p.a. da Casa Americana. O peróxido de uréia $98 \%$ foi adquirido do laboratório Sigma-Aldrich. Todos os reagentes foram pesados em balança analítica com precisão de $\pm 0,0001 \mathrm{~g}$. 


\subsection{Preparação das amostras}

Foram preparadas as seguintes amostras:

Solução MOPS: preparou-se uma solução tampão adicionando 2,09 g de MOPS em $1000 \mathrm{~mL}$ de água bideionizada. $\mathrm{O} \mathrm{pH}$ da solução foi ajustado para 6,9 através do acréscimo de $\mathrm{NaOH}$, pois o MOPS em água bideionizada possui um $\mathrm{pH}$ mais ácido que o desejado.

Solução TCs: $21 \mathrm{mmolL}^{-1}$ das tetraciclinas (Tc, OTc, CTc, MTc) completando o volume com a Solução MOPS para $100 \mathrm{~mL}$.

Solução EuTCs: foram preparadas amostras de európio em diferentes concentrações molares para a quantidade fixa de $21 \mathrm{\mu molL}^{-1}$ das tetraciclinas (EuTc, EuOTc, EuCTc, EuMTc) completando o volume com a Solução MOPS para $100 \mathrm{~mL}$, como mostra a Tabela 3.

Tabela 3- Amostras do complexo európio tetraciclinas.

\begin{tabular}{ccc}
\hline Proporção Eu:TCs & $\mathbf{E u}^{3+}\left(\boldsymbol{\mu \mathbf { m o l L } ^ { - 1 } )}\right.$ & $\mathbf{T C}\left(\boldsymbol{\mu \mathrm { molL } ^ { - 1 } )}\right.$ \\
\hline 1,0Eu:1,0Tc & 21,00 & 21,00 \\
1,5Eu:1,0Tc & 31,50 & 21,00 \\
2,0Eu:1,0Tc & 42,00 & 21,00 \\
2,5Eu:1,0Tc & 52,50 & 21,00 \\
3,0Eu:1,0Tc & 63,00 & 21,00 \\
3,5Eu:1,0Tc & 73,50 & 21,00 \\
4,0Eu:1,0Tc & 84,00 & 21,00 \\
\hline
\end{tabular}

Solução-mãe $P H: 11,5 \mu \mathrm{L}$ de peróxido de hidrogênio $30 \%$ p.a. dissolvidos em $100 \mathrm{~mL}$ de água bideionizada, obtendo $100 \mathrm{~mL}$ de uma solução de peróxido de hidrogênio $1000 \mu \mathrm{M}$. 
Solução-mãe PHU: 0,009407 g de peróxido de uréia dissolvidos em $100 \mathrm{~mL}$ de água bideionizada, obtendo $100 \mathrm{~mL}$ de uma solução de peróxido de uréia $1000 \mu \mathrm{M}$.

Solução EuTCs-PH : $1 \mathrm{~mL}$ da Solução EuTC acrescidas de $1 \mathrm{~mL}$ de solução de $\mathrm{PH}$ em diversas concentrações molares $(0$ à $1000 \mu \mathrm{M})$ que foram preparadas à partir da Solução-mãe $P H$, completando com água bideionizada quando necessário para um volume final de $2 \mathrm{~mL}$.

Solução EuTCs-PHU : $1 \mathrm{~mL}$ da Solução EuTC acrescidas de $1 \mathrm{~mL}$ da solução de PHU em diversas concentrações molares (0 à $1000 \mu \mathrm{M})$ que foram preparadas à partir da Soluça-mãe $P H U$, completando com água bideionizada quando necessário para um volume final de $2 \mathrm{~mL}$.

Solução EuTC-Glicose: $1 \mathrm{~mL}$ da Solução EuTC + $50 \mu \mathrm{L}$ Glicose nas concentrações de 50, 100 e $200 \mathrm{mg} / \mathrm{dL}$, estas preparadas a partir de uma solução mãe de 250 $\mathrm{mg} / \mathrm{dL}$ de glicose.

Solução EuTC-Glicose-Gox: $1 \mathrm{~mL}$ Solução EuTC $+5 \mu \mathrm{L}$ Gox $+50 \mu \mathrm{L}$ Glicose em diversas concentrações ( 0 à $225 \mathrm{mg} / \mathrm{dL}$ ), preparadas a partir de uma solução mãe de $250 \mathrm{mg} / \mathrm{dL}$ de glicose.

Solução de Interferentes: $500 \mu \mathrm{L}$ Solução EuTC + $500 \mu \mathrm{L}$ de PHU ou PH $500 \mu \mathrm{M}+$ $500 \mu \mathrm{L}$ da solução com interferente inorgânico. Os interferentes e concentrações utilizados seguem na Tabela 4. As concentrações correspondem à valores encontrados normalmente no sangue $e$ as soluções de interferentes foram preparadas com água bideionizada.

Tabela 4 - Valores de referência dos componentes inorgânicos estudados.

\begin{tabular}{c|c}
\hline \hline Interferente & Valor de Referência no Sangue \\
\hline \hline $\mathrm{Zn}$ & $20 \mu \mathrm{M}^{64}$ \\
\hline
\end{tabular}




\begin{tabular}{c|c}
\hline $\mathrm{Al}$ & $12 \mu \mathrm{M}^{65}$ \\
\hline $\mathrm{Ca}$ & $1,12 \mu \mathrm{M}^{66}$ \\
\hline $\mathrm{Co}$ & $0,1 \mu \mathrm{M} \mathrm{64}$ \\
\hline $\mathrm{Cu}$ & $11,02 \mu \mathrm{M}^{67}$ \\
\hline $\mathrm{Fe}$ & $10,74 \mu \mathrm{M} \mathrm{67}$ \\
\hline $\mathrm{Mg}$ & $0,75 \mathrm{mMa} \mathrm{mM} \mathrm{67}$ \\
\hline $\mathrm{Mn}$ & $0,2 \mu \mathrm{M} \mathrm{64}$ \\
\hline $\mathrm{Ni}$ & $0,1 \mu \mathrm{M} \mathrm{64}$ \\
\hline $\mathrm{Ag}$ & $0,093 \mu \mathrm{M}^{68}$ \\
\hline
\end{tabular}




\section{RESULTADOS E DISCUSSÃO}

\subsection{Estudos dos Reagentes e Complexos Európio-Tetraciclinas}

A base das soluções de európio-tetraciclina são feitas utilizando o tampão MOPS (Figura 6) a fim de manter o pH da solução neutro, mais precisamente em 6.9. Estudos mostram que para melhor complexação do íon európio com a tetraciclina o $\mathrm{pH}$ neutro é o ideal2 ${ }^{30,53}$.

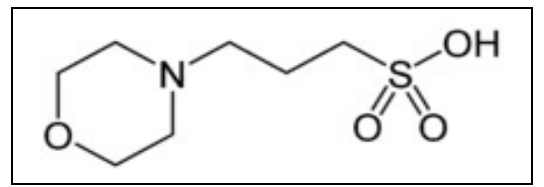

Figura 6 - Estrutura do ácido propanosulfônico 3-(N-morfolino) ou MOPS.

A Figura 7 mostra os espectros de absorção óptica da solução de MOPS, do íon európio $63 \mu \mathrm{molL}^{-1}$ em solução de MOPS, e das soluções-mãe dos peróxidos de hidrogênio e uréia na concentração molar de $1000 \mu \mathrm{M}$, realizados nos comprimentos de onda entre 200 e $500 \mathrm{~nm}$. Nenhum dos reagentes apresenta absorção neste intervalo, não interferindo assim no complexo EuTC.

Observa-se que o íon európio possui um baixo coeficiente de absorção, resultado das transições proibidas $\mathrm{f}-\mathrm{f} 12$.

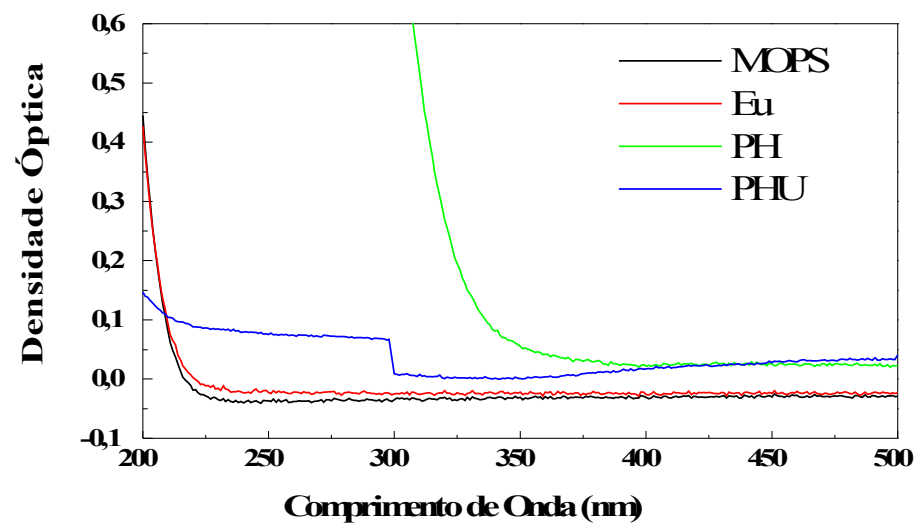

Figura 7 - Espectro de absorção óptica do tampão MOPS, íon európio em solução MOPS, solução-mãe PH e solução-mãe PHU. 
As candidatas ao nosso estudo da família das Tetraciclinas: oxitetraciclina (OTc), clorotetraciclina (CTc) e metaciclina (MTc) apresentam, em solução, um amplo espectro de absorção característico de compostos orgânicos e, quando em solução com európio, apresentam um deslocamento de absorção para o vermelho, indicando a formação do complexo EuTC (Figura 8). A OTc e CTc sofrem um deslocamento para um maior comprimento de onda de aproximadamente $30 \mathrm{~nm}$ quando complexadas com európio. Na solução MTc o deslocamento foi de $40 \mathrm{~nm}$. As Tetraciclinas em solução preparadas com concentração molar de $21 \mu \mathrm{molL}^{-1}$ e o os complexos EuTC nas razões molares 1:1; 1:2; 1:3 e 1:4.
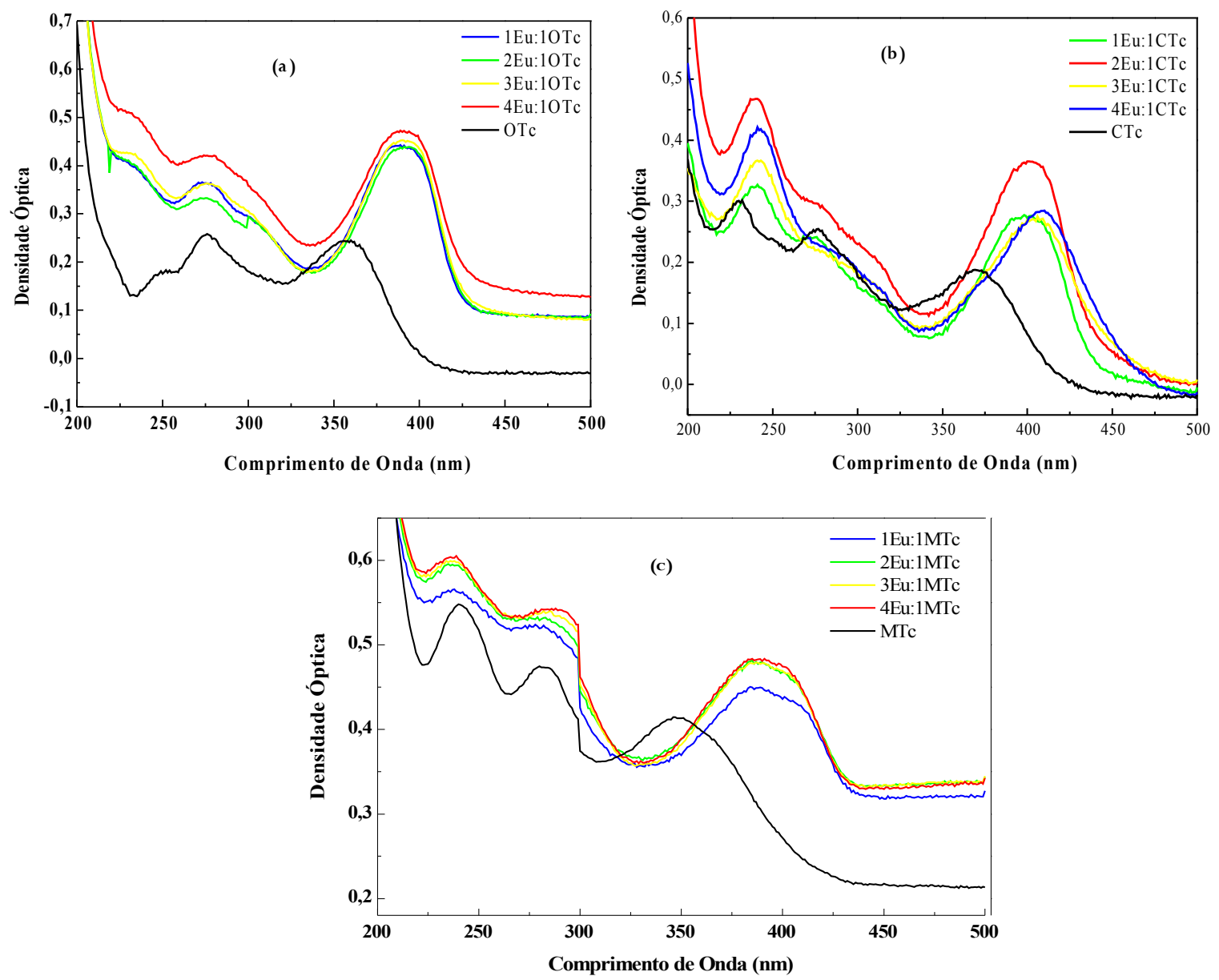

Figura 8 - Espectro de absorção óptica: (a) complexo EuOTc e OTc, (b) complexo EuCTc e CTc, (c) complexo EuMTc e MTc. 
O complexo EuTC mantém a banda larga de absorção característica do ligante orgânico, indicando que a energia absorvida pelo quelato ocorre através deste. É possível observar que para diferentes razões molares de EuTC a absorção do complexo permanece praticamente no mesmo comprimento de onda.

A Figura 9(a) mostra a emissão das amostras da solução de OTc 21 $\mu \mathrm{molL}^{-1}$ e do íon európio $21 \mu \mathrm{molL}^{-1}$, excitadas respectivamente em $357 \mathrm{~nm}$ e 390 $\mathrm{nm}$.
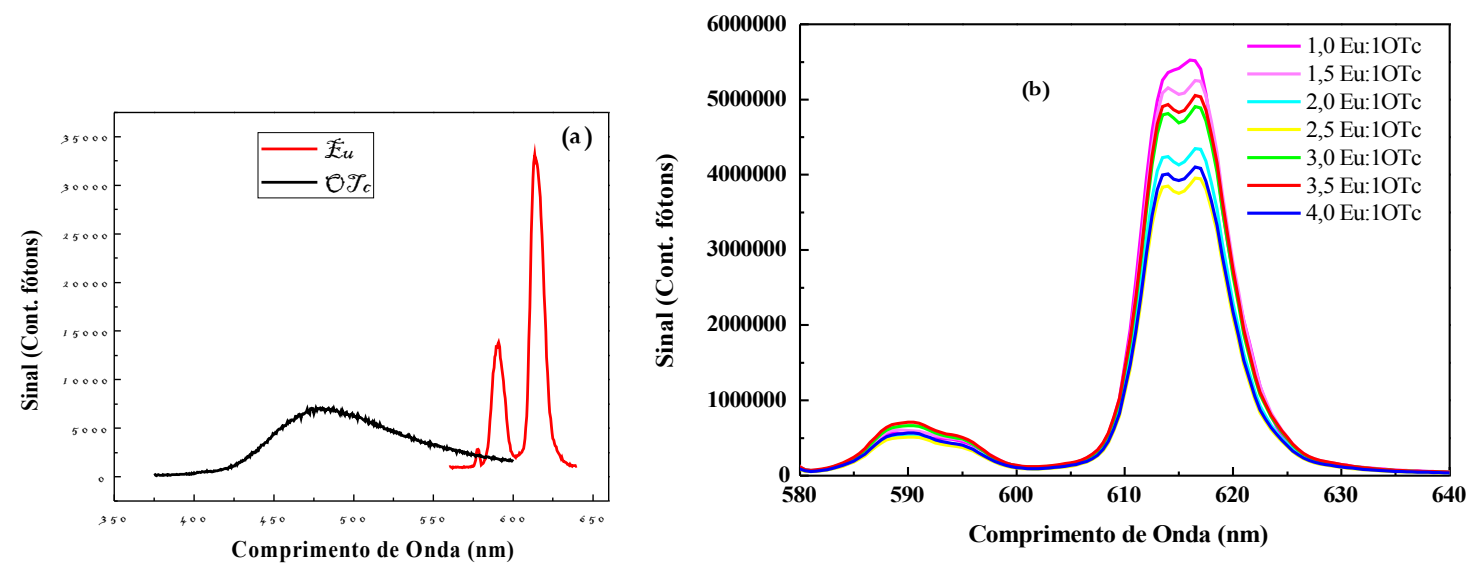

Figura 9 - (a) Espectro de emissão óptica das soluções de OTc e do íon európio. (b) Emissão óptica do complexo EuOTc em diversas razões molares.

A OTc possui um amplo banda de emissão, característico dos compostos orgânicos, com máximo em torno de $480 \mathrm{~nm}$, com emissão de 7.000 fótons. 0 európio apresenta banda de emissão com picos finos e bem definidos em: $578 \mathrm{~nm}$, $590 \mathrm{~nm}$ e $614 \mathrm{~nm}$, este último com emissão máxima em torno de 33.000 fótons.

O espectro de emissão do EuOTc é mostrado na Figura 9(b), com excitação em $390 \mathrm{~nm}$. A razão molar 1Eu:10Tc foi a que obteve maior intensidade na emissão, em torno de 5.500 .000 fótons, ou seja, um aumento na emissão de mais de 150 vezes em relação ao íon európio em solução. Todas as razões molares estudadas emitiram no mesmo comprimento de onda, com máximo em aproximadamente $615 \mathrm{~nm}$. Isto ocorre porque o ligante orgânico absorve energia transferindo-a ao estado tripleto do íon metálico central, que emite a radiação em 
uma banda estreita e bem definida, devido à transição ${ }^{5} D_{0} \rightarrow{ }^{7} F_{2}$ dos íons európio (efeito antena).

Os espectros de emissão da CTc e do seu complexo com o íon európio (Figura 10), assim como os da MTc e do complexo EuMTc (Figura 11) demonstram o mesmo fenômeno de transferência de energia intramolecular entre o ligante orgânico e o lantanídeo descrito anteriormente. As soluções CTc e EuCTc foram excitadas em 370 e 400 nm, enquanto a solução MTc e EuMTc foram excitadas em 350 e 390 nm respectivamente.
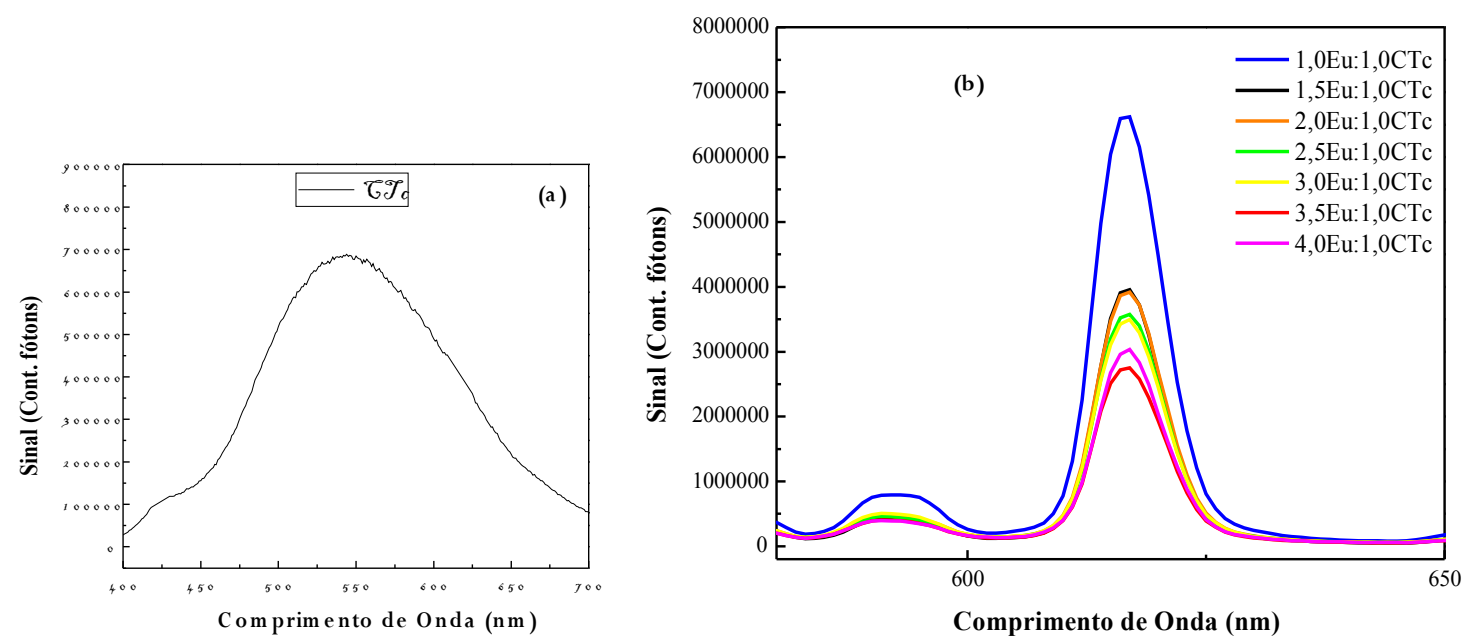

Figura 10 - (a) Espectro de emissão óptica da solução CTc. (b) Emissão óptica do complexo EuCTc em diversas razões molares.
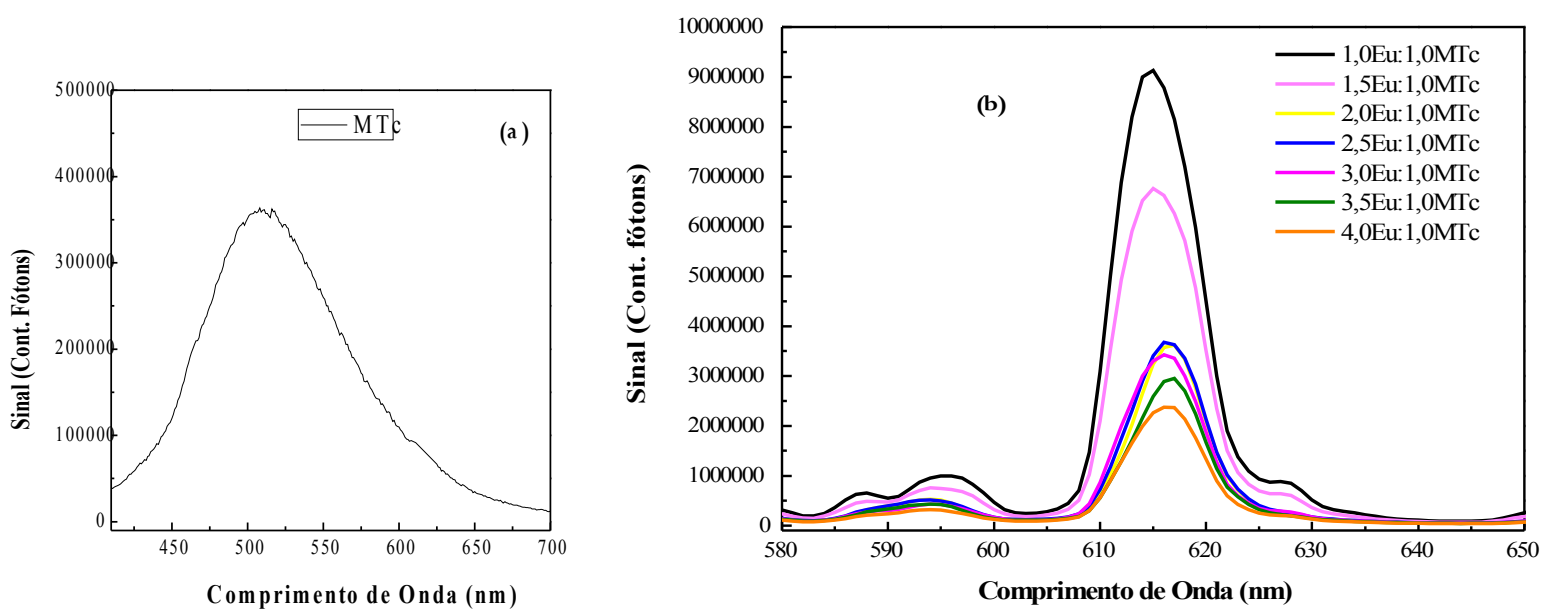

Figura 11 - (a) Espectro de emissão óptica da solução MTc. (b) Emissão óptica do complexo EuMTc em diversas razões molares. 
$\mathrm{Na}$ Tabela 5 é apresentado o grande deslocamento entre a absorção e emissão dos complexos EuTCs, importante característica que evita a sobreposição dos espectros de excitação e emissão.

Tabela 5 - Deslocamento dos picos de absorção e emissão dos complexos EuOTc, EuCTc e EuMTc

\begin{tabular}{cccc}
\hline EuTC & Absorção $(\mathbf{n m})$ & Emissão $(\mathbf{n m})$ & Deslocamento $(\mathbf{n m})$ \\
\hline$E u O T c$ & 390 & 615 & $\mathbf{2 2 5}$ \\
\hline$E u C T c$ & 400 & 615 & $\mathbf{2 1 5}$ \\
\hline$E u M T c$ & 390 & 615 & $\mathbf{2 2 5}$ \\
\hline
\end{tabular}

\subsection{Determinação das curvas de calibração}

Uma curva de calibração permite a determinação da concentração de uma substância em uma amostra desconhecida, comparando o desconhecido a um conjunto de amostras padrão de concentração conhecida. Os dados - as concentrações do analito (peróxido de hidrogênio, peróxido de uréia, glicose, etc.) e a resposta do instrumento para cada padrão - podem ser ajustados como uma linha reta de equação $y=a+b^{*} x$, onde y é a resposta do instrumento de medida, $x$ corresponde à concentração do peróxido, $b$ (coeficiente angular da reta) representa o ruído de fundo e a (coeficiente linear) descreve a sensibilidade. A concentração do analito das amostras desconhecidas ('x) pode ser calculada a partir desta equação.

Outro fator a ser considerado é o limite de detecção (LD) que corresponde à menor quantidade do analito capaz de ser detectado em uma amostra ${ }^{69}$. O LD pode ser calculado a partir da seguinte fórmula:

$$
L D=3 * \frac{\text { desvio padrão do parâmetro } b}{\text { Coeficiente angular da curva de calibração }}
$$

Para a construção da curva de calibração dos complexos EuOTc, EuCTc e EuMTc com o peróxido de hidrogênio e peróxido de uréia primeiramente foi 
determinada a melhor razão molar de Eu:TC para a formação do complexo, considerando a melhor razão molar aquela que apresenta maior intensidade de luminescência. Logo, foram preparadas amostras em diversas concentrações molares de európio $(1,0 ; 1,5 ; 2,0 ; 2,5 ; 3,0 ; 3,5 ; 4,0)$ para 1 de Tetraciclina (OTc, CTc e MTc), acrescidas de peróxido de hidrogênio ou uréia em uma concentração fixa, no caso $500 \mu \mathrm{M}$. Encontrada a melhor razão de EuTC, foram obtidos os espectros de emissão variando a concentração dos peróxidos. Os espectros de emissão foram feitos entre os comprimentos de onda 580 e $650 \mathrm{~nm}$, intervalo em que ocorre o maior pico de emissão do complexo. A curva de calibração foi construída através da integral do espectro de cada amostra para a concentração do analito em questão.

Os resultados foram comparados com o complexo Európio-Tetraciclina (EuTc), este amplamente estudado na detecção de peróxidos de hidrogênio52,53 e uréia40,7. A curva de calibração da EuTc foi construída baseando-se em estudos prévios que demonstram que a melhor razão molar de EuTc para a realização dos experimentos é de 1:3 e que o complexo possui pico de absorção com máximo no comprimento de onda em $400 \mathrm{~nm} 2^{30}$.

\subsubsection{Complexos EuTC-PH}

Foram obtidos os espectros de absorção dos complexos EuOTc, EuCTc e EuMTc na presença de PH (Figura 12). As amostras foram preparadas em diversas concentrações molares de Eu:TC $(1: 1 ; 2: 1 ; 3: 1$ e 4:1) acrescidas de peróxido de hidrogênio $500 \mu \mathrm{M}$.

Pode-se observar que a posição das bandas de absorção dos EuTCs não se alteram com a presença de $\mathrm{PH}$, havendo apenas alteração na intensidade. Os picos de absorção mantiveram-se em 390 nm nos complexos EuOTc-PH e EuMTc-PH, 400 nm no complexo EuCTc-PH. 

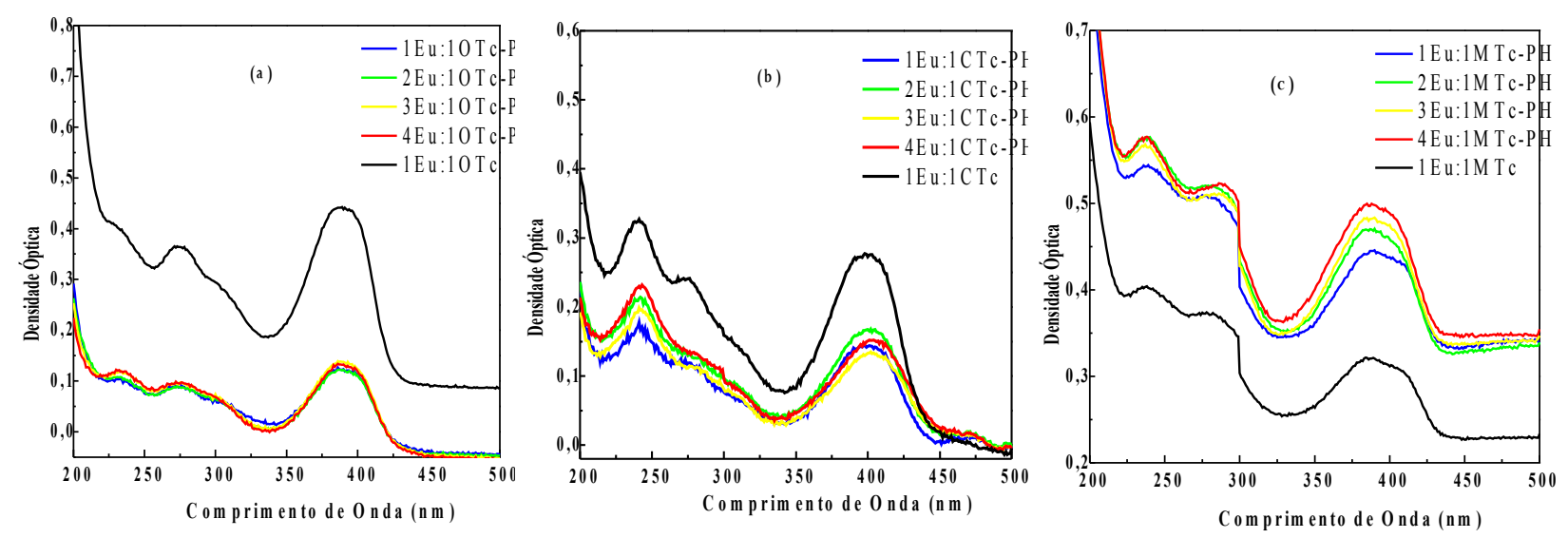

Figura 12 - Espectro de absorção óptica dos complexos (a)EuOTc, (b)EuCTc, (c)EuMTc, em diferentes concentrações molares, com e sem PH.

Os espectros de luminescência das EuTC com PH $500 \mu \mathrm{M}$ estão apresentados na Figura 13. As soluções foram excitadas nos comprimentos de onda obtidos nos experimentos dos espectros de absorção realizados anteriormente: 390 nm para os complexos EuOTc-PH e EuMTc-PH; 400 nm para o complexo EuCTc$\mathrm{PH}$. 

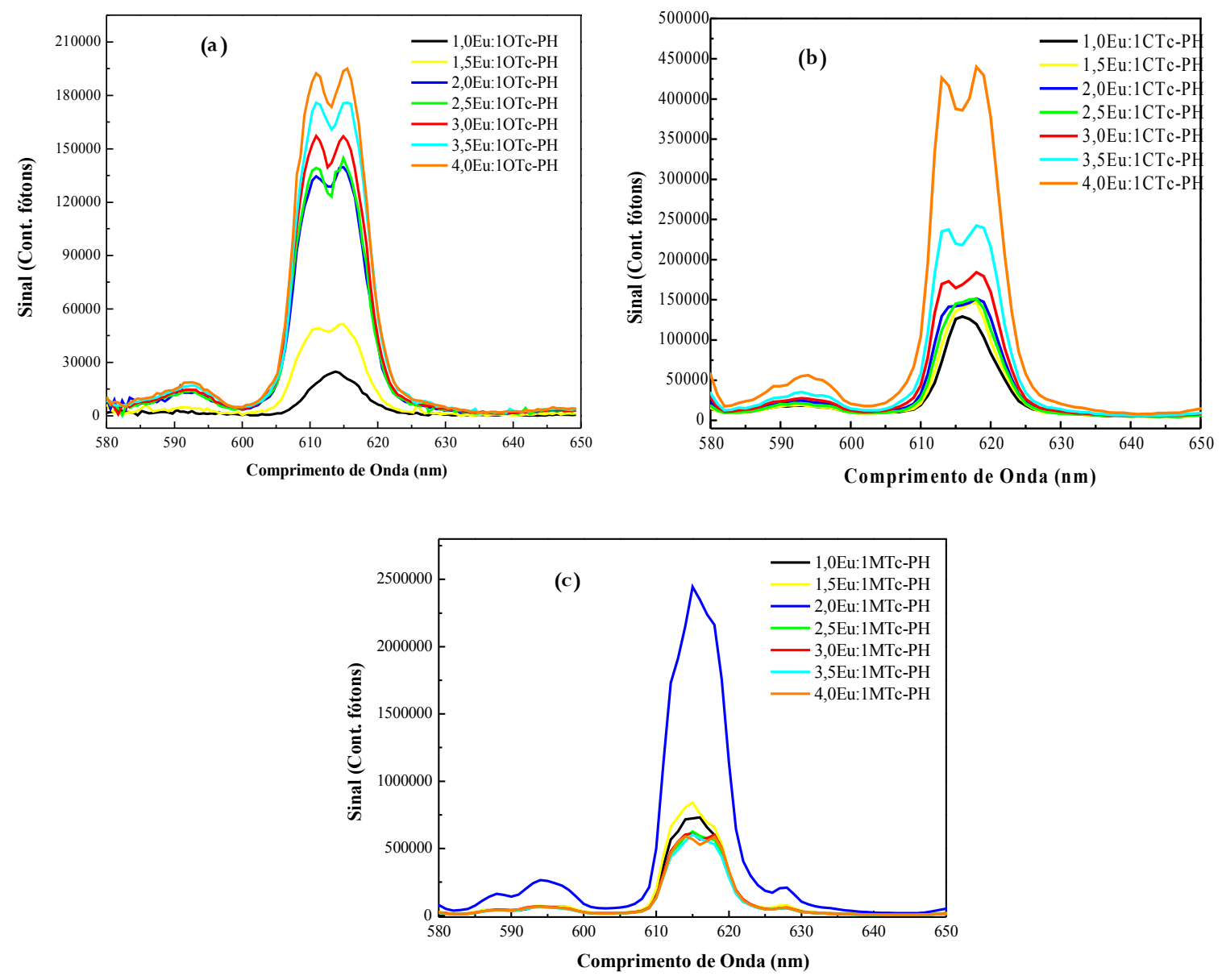

Figura 13 - Espectro de emissão dos complexos: (a) EuOTc-PH, (b) EuCTc-PH, (c) EuMTc-PH, em diferentes concentrações molares EuTC.

Assim, os resultados com a razão molar com maior intensidade de emissão seguem na Tabela 6 abaixo:

Tabela 6 - Razões molares do EuTC na presença de PH que obtiveram emissão com maior intensidade.

\begin{tabular}{c|c}
\hline \hline EuTC & $\begin{array}{l}\text { Razão Molar Eu:TC, na } \\
\text { presença de PH 500 } \mu \mathrm{M}\end{array}$ \\
\hline \hline EuOTc & $4: 1$ \\
\hline EuCTc & $4: 1$ \\
\hline EuMTc & $2: 1$ \\
\hline
\end{tabular}

A partir do resultado anterior, foram preparadas amostras dos complexos 4Eu:1OTc, 4Eu:1CTc e 2Eu:1MTc com PH variando a concentração deste de 0 até 
$1000 \mu \mathrm{M}$. As soluções foram então excitadas nos comprimentos de onda $390 \mathrm{~nm}$ para os complexos EuOTc-PH e EuMTc-PH, $400 \mathrm{~nm}$ para o complexo EuCTc-PH. Para comparação dos resultados, o complexo EuTc foi preparado a razão molar de 3:1 acrescido de $\mathrm{PH}$ em diversas concentrações molares, excitado em $400 \mathrm{~nm}$.

Os resultados obtidos para a EuTc-PH são exibidos na Figura 14. A curva de calibração mostrou um aumento relativamente linear de 0 a $600 \mu \mathrm{M}$, com um aumento na emissão em 7 vezes se comparado ao complexo sem $\mathrm{PH}$. O limite de detecção do EuTc-PH é de $0,17 \mathrm{mg} / \mathrm{mL}$. 

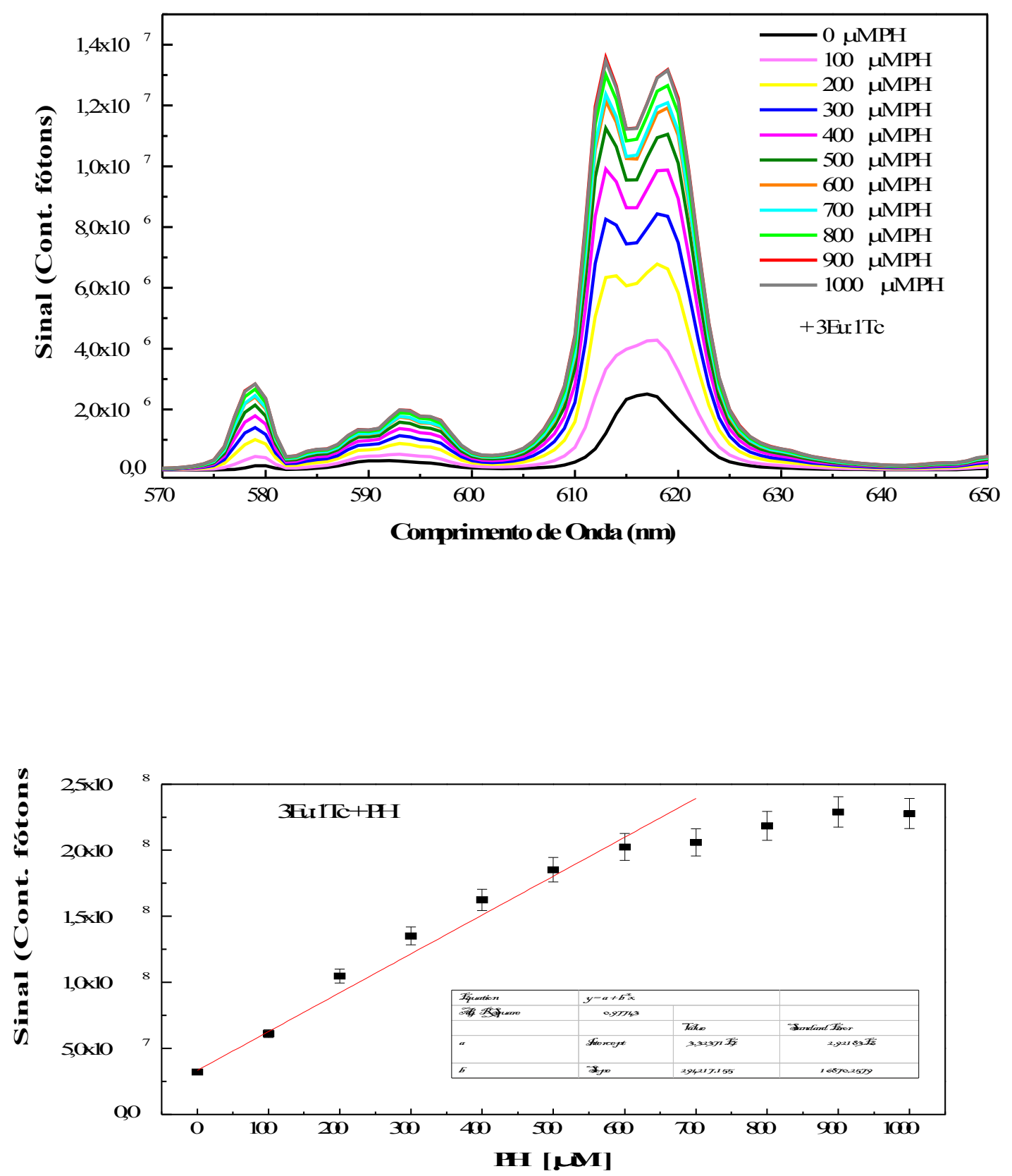

Figura 14 - (a) Espectro de emissão (b) e curva de calibração do complexo 3Eu:1Tc-PH.

O complexo EuCTc-PH obteve um aumento na luminescência de quase 7,2 vezes em relação ao EuCTc (Figura 15). A emissão aumentou de 15 milhões de fótons para 110 milhões de fótons na presença de $\mathrm{PH}$. A curva de calibração mostrou-se linear entre 100 a $700 \mu \mathrm{M}$. O limite de detecção obtido foi de 0,06 mg/mL. 

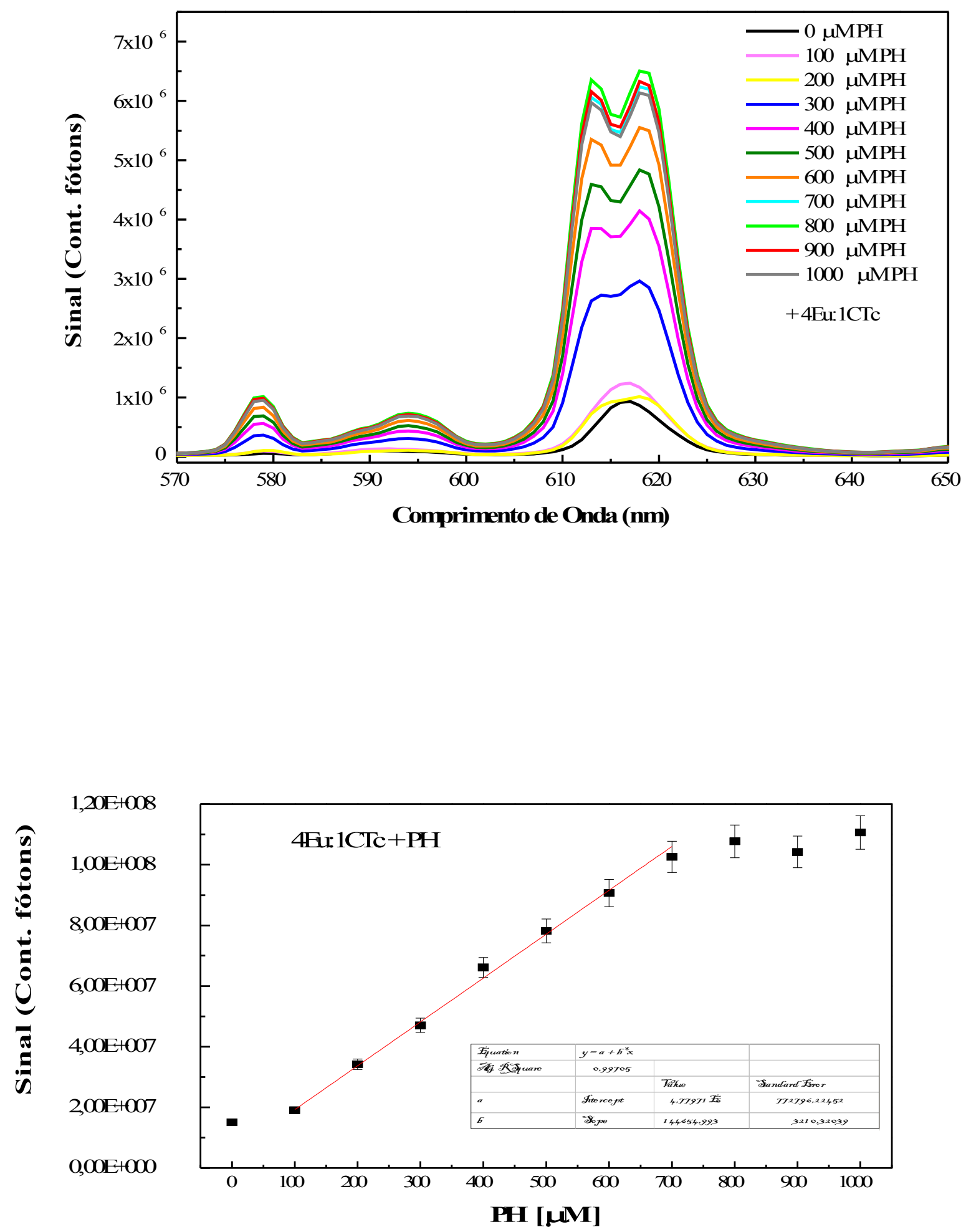

Figura 15 - (a) Espectro de emissão e (b) curva de calibração complexo 4Eu:1CTc-PH. 
A curva de calibração do complexo EuOTc também mostrou um aumento linear de 0 a $600 \mu \mathrm{M}$ (Figura 16). $\mathrm{O}$ aumento na intensidade de luminescência foi menor que os anteriores, de aproximadamente 4 vezes em relação ao complexo sem $\mathrm{PH}$. O limite de detecção para o EuOTc-PH é de $0,12 \mathrm{mg} / \mathrm{mL}$. 

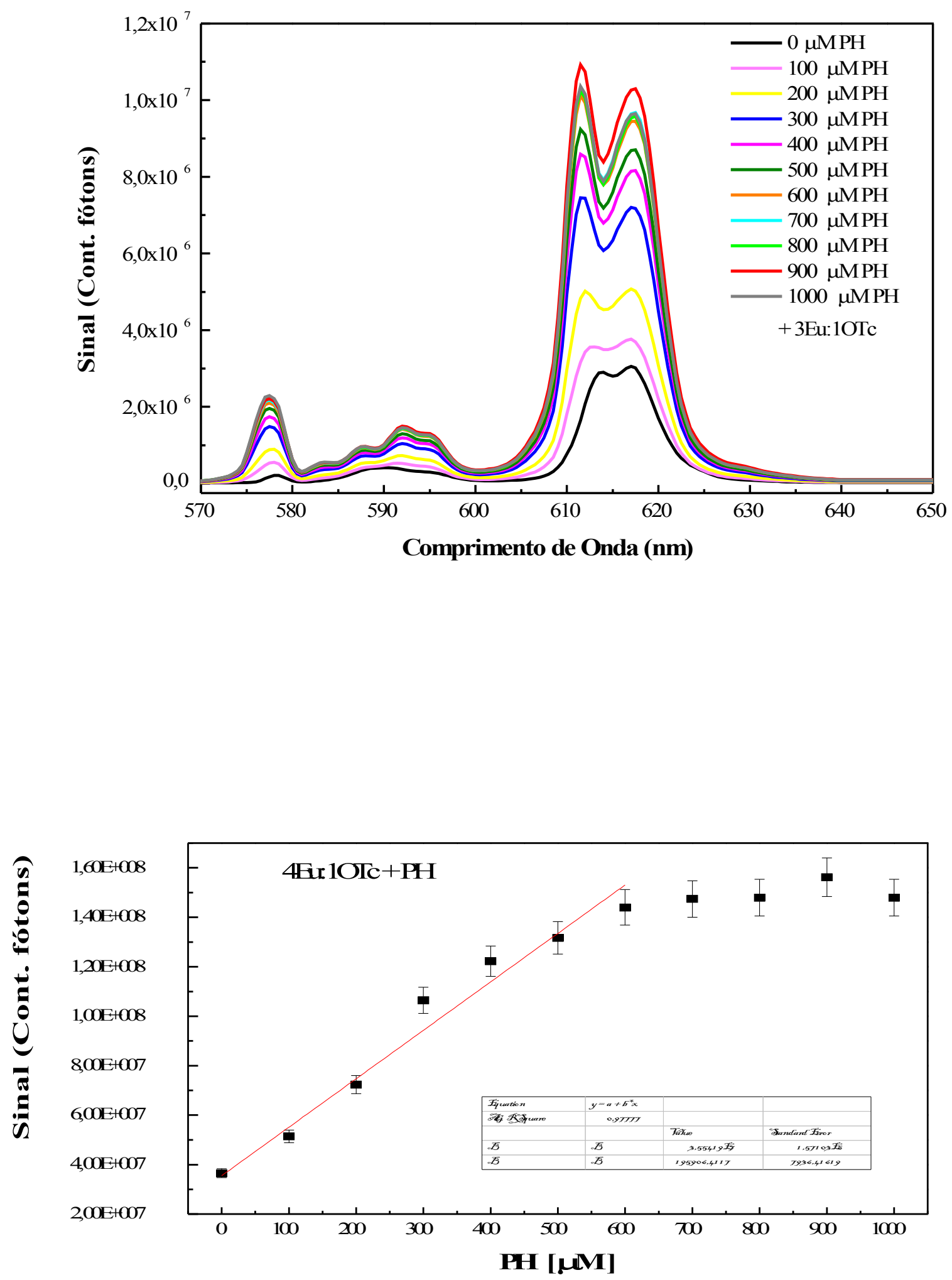

Figura 16 - (a) Espectro de emissão e (b) curva de calibração do complexo 4Eu:10Tc-PH. 
O espectro de emissão e curva de calibração do complexo EuMTc-PH é apresentado na Figura 17. Pode-se observar que não houve alteração na emissão do complexo EuMTc na presença de PH.
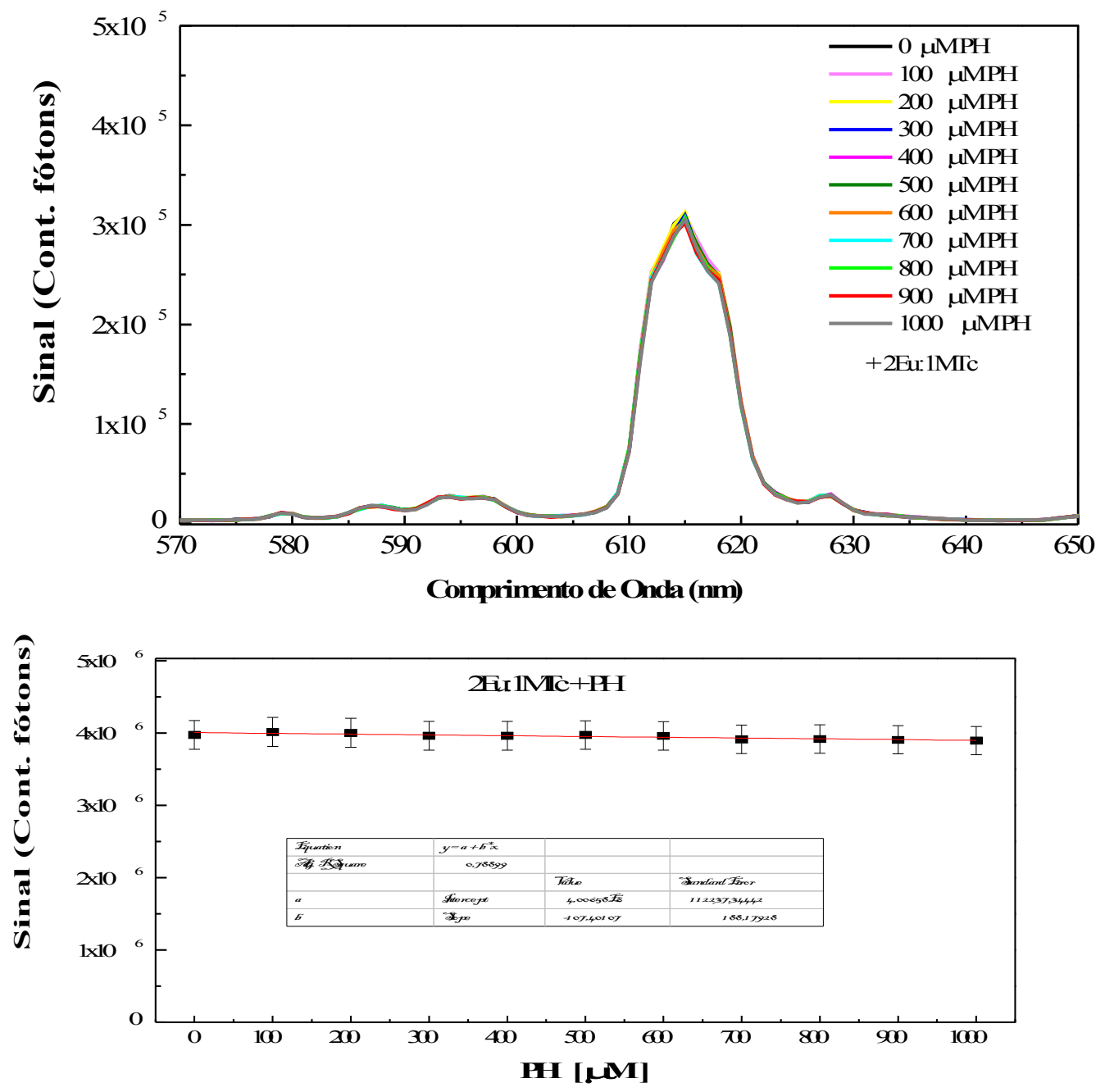

Figura 17 - (a) Espectro de emissão e (b) curva de calibração do complexo 2Eu:1MTc-PH.

É possível observar no espectro de emissão que em torno da transição ${ }^{5} D_{0} \rightarrow$ ${ }^{7} \mathrm{~F}_{2}$ a banda apresenta dois picos, o que pode significar que existam diferentes sítios de ligação para o európio na molécula da tetraciclina quando em presença de $\mathrm{PH}$. Especificamente no caso do complexo EuOTc nota-se que isto ocorre mesmo sem a presença de $\mathrm{PH}$. 
O aumento da luminescência com a adição do peróxido ocorre devido à substituição de moléculas da água na coordenação do európio (que diminuem a intensidade de emissão) pelo $\mathrm{H}_{2} \mathrm{O}_{2}$. Além disso, estudos sugerem que o peróxido de hidrogênio promove uma reorganização estrutural do complexo EuTc em solução aumentando a proximidade do íon metálico central com os ligantes orgânicos, o que permitiria maior eficiência na transferência de energia intramolecular6.

O complexo EuMTc, ao contrário dos outros, não sofre aumento na emissão em presença de $\mathrm{PH}$. Isto ocorre provavelmente porque não há um aumento no número de sítios de ligação da molécula com a presença do peróxido.

\subsubsection{Complexos EuTC-PHU}

A Figura 18 mostra os espectros de absorção dos complexos EuOTc, EuCTc e EuMTc na presença de PHU. As amostras foram preparadas em diversas razões molares de Eu:TC $(1: 1 ; 2: 1 ; 3: 1$ e 4:1) acrescidas de peróxido de uréia $500 \mu \mathrm{M}$. Não há alteração significativa do comprimento de onda de absorção das amostras na ausência ou presença do peróxido de uréia. Os picos de absorção mantiveram-se em $390 \mathrm{~nm}$ nos complexos EuOTc-PHU e EuCTc- PHU, 400 nm no complexo EuCTcPHU.
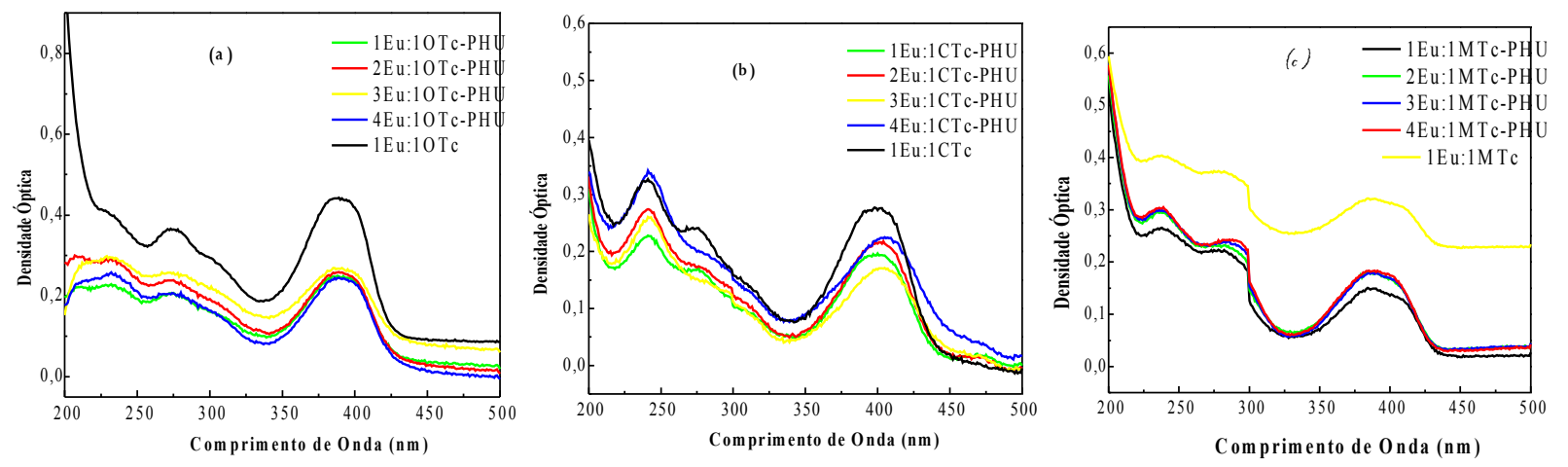

Figura 18 - Espectro de absorção óptica dos complexos (a)EuOTc, (b)EuCTc, (c)EuMTc, em diferentes concentrações molares sem PHU e com PHU.

Os espectros de emissão das EuTC com PHU $500 \mu \mathrm{M}$ são apresentados na Figura 19. As soluções foram excitadas nos comprimentos de onda obtidos nos 
experimentos dos espectros de absorção realizados anteriormente: $390 \mathrm{~nm}$ para os complexos EuOTc- PHU e EuMTc- PHU; 400 nm para o complexo EuCTc- PHU.
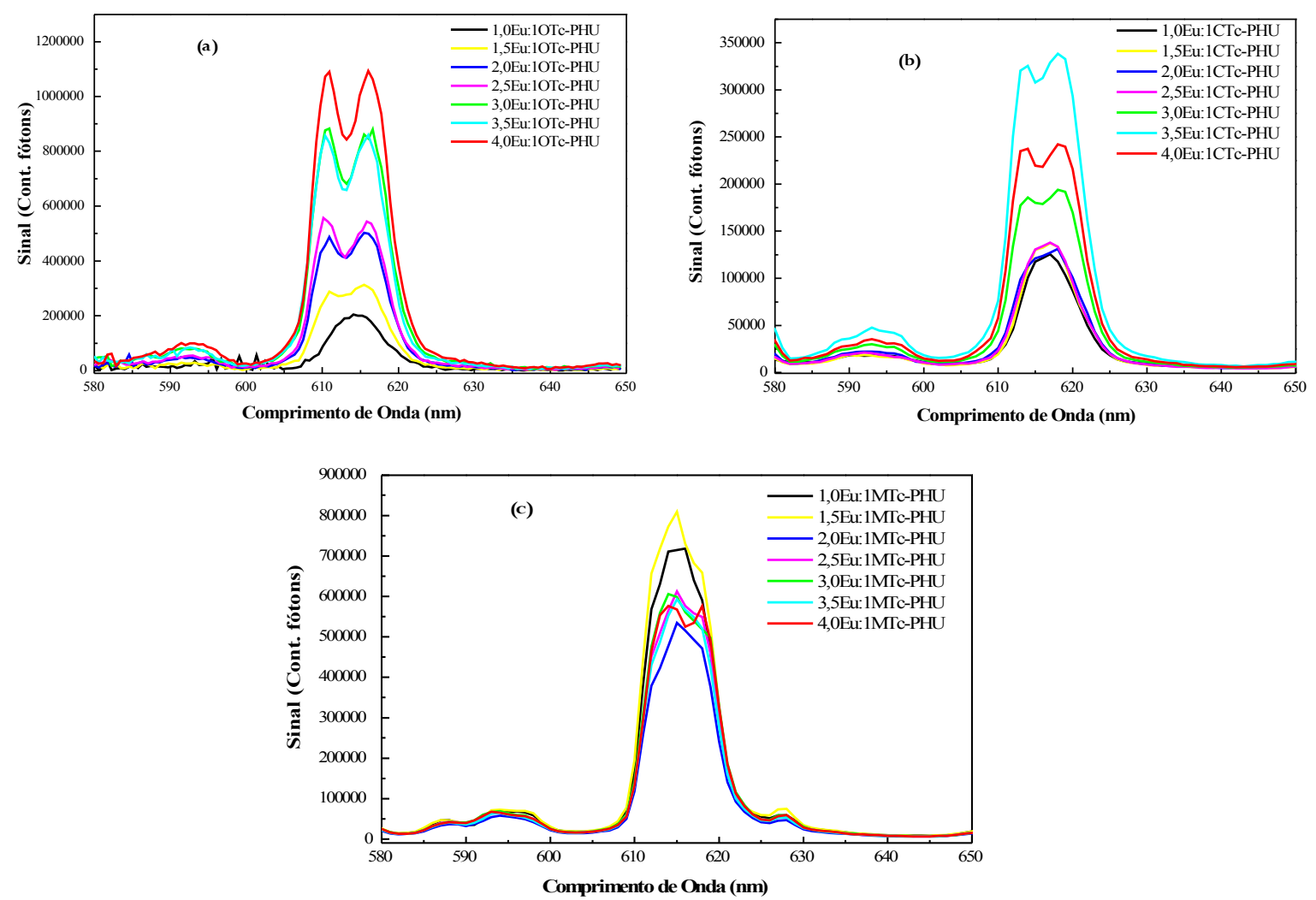

Figura 19 - Espectro de emissão dos complexos (a) EuOTc-PHU, (b) EuCTc-PHU, (c) EuMTc-PHU, em diferentes concentrações molares de EuTC.

Os resultados com a razão molar com maior intensidade de emissão seguem na Tabela 7.

Tabela 7 - Razão molar do EuTC na presença de PHU que obteve emissão com maior intensidade.

\begin{tabular}{c||c}
\hline \hline EuTC & $\begin{array}{c}\text { Razão Molar Eu:TC, na } \\
\text { presença de PHU 500 } \mu \mathrm{M}\end{array}$ \\
\hline \hline EuOTc & $4,0: 1$ \\
\hline EuCTc & $3,5: 1$ \\
\hline EuMTc & $1,5: 1$ \\
\hline
\end{tabular}


De acordo com o resultado obtido, foram preparadas amostras dos complexos 4Eu:1OTc, 3,5Eu:1CTc e 1,5Eu:1MTc com diversas concentrações molares de PHU. As soluções foram novamente excitadas nos comprimentos de onda $390 \mathrm{~nm}$ para os complexos EuOTc- PHU e EuMTc- PHU, 400 nm para o complexo EuCTc- PHU. Para comparação dos resultados, o complexo EuTc foi preparado a razão molar de 3:1, e excitado em $400 \mathrm{~nm}$.

A Figura 20 apresenta o espectro de emissão e curva de calibração do complexo EuTc-PHU. A curva de calibração mostrou boa linearidade de 0 a $1000 \mu \mathrm{M}$ de PHU e houve um aumento em torno de 7 vezes na emissão da luminescência. $O$ limite de detecção obtido para o complexo foi de $0,076 \mathrm{mg} / \mathrm{mL}$.
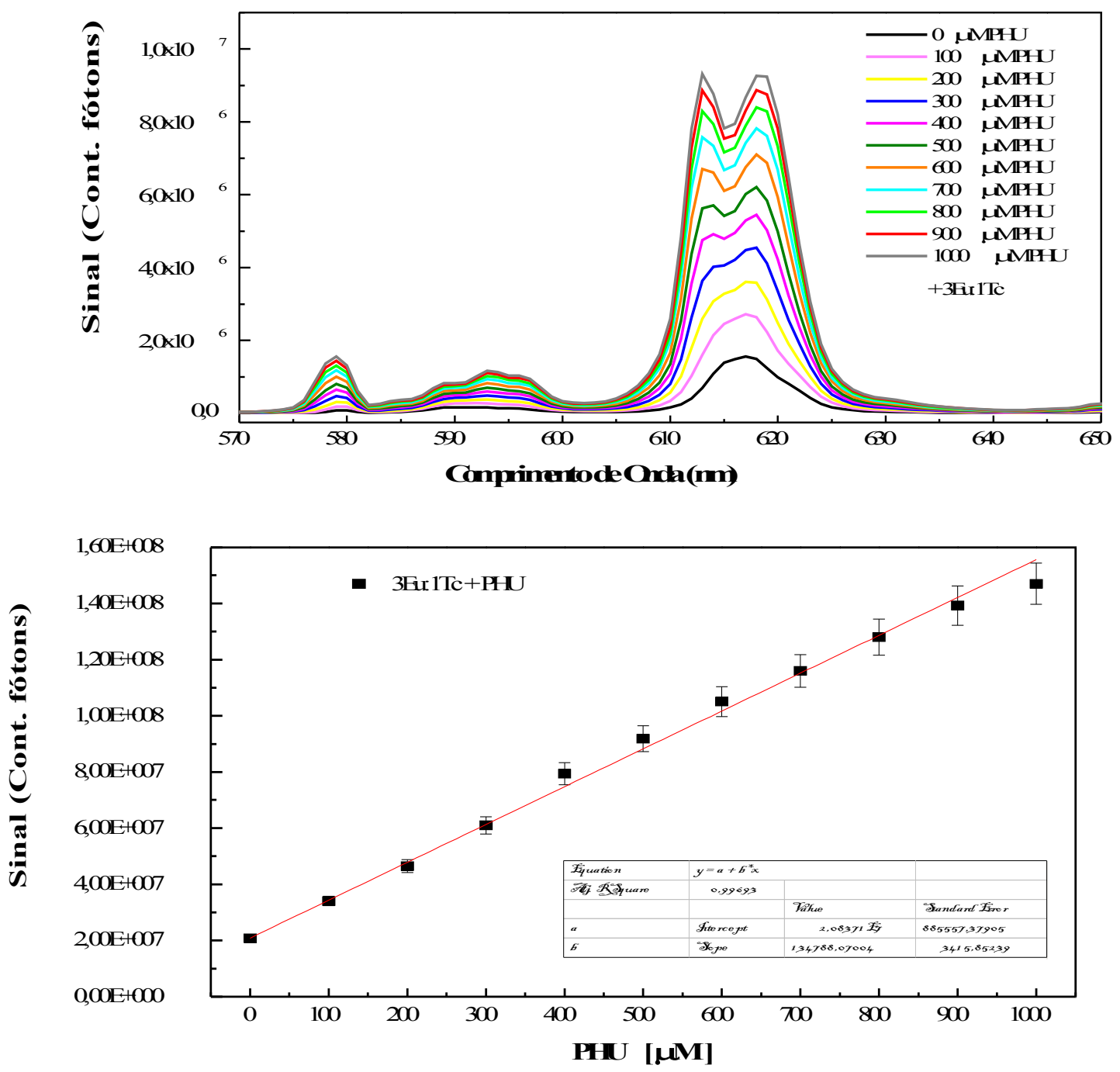

Figura 20 - (a) Espectro de emissão e (b) curva de calibração do complexo 3Eu:1Tc-PHU. 
$\mathrm{Na}$ presença de PHU a curva de calibração para o EuOTc mostrou-se relativamente linear de 0 até $500 \mu \mathrm{M}$ com um aumento na luminescência de 4,8 vezes em relação ao complexo sem o peróxido (Figura 21). O limite de detecção obtido é de $0,24 \mathrm{mg} / \mathrm{mL}$.
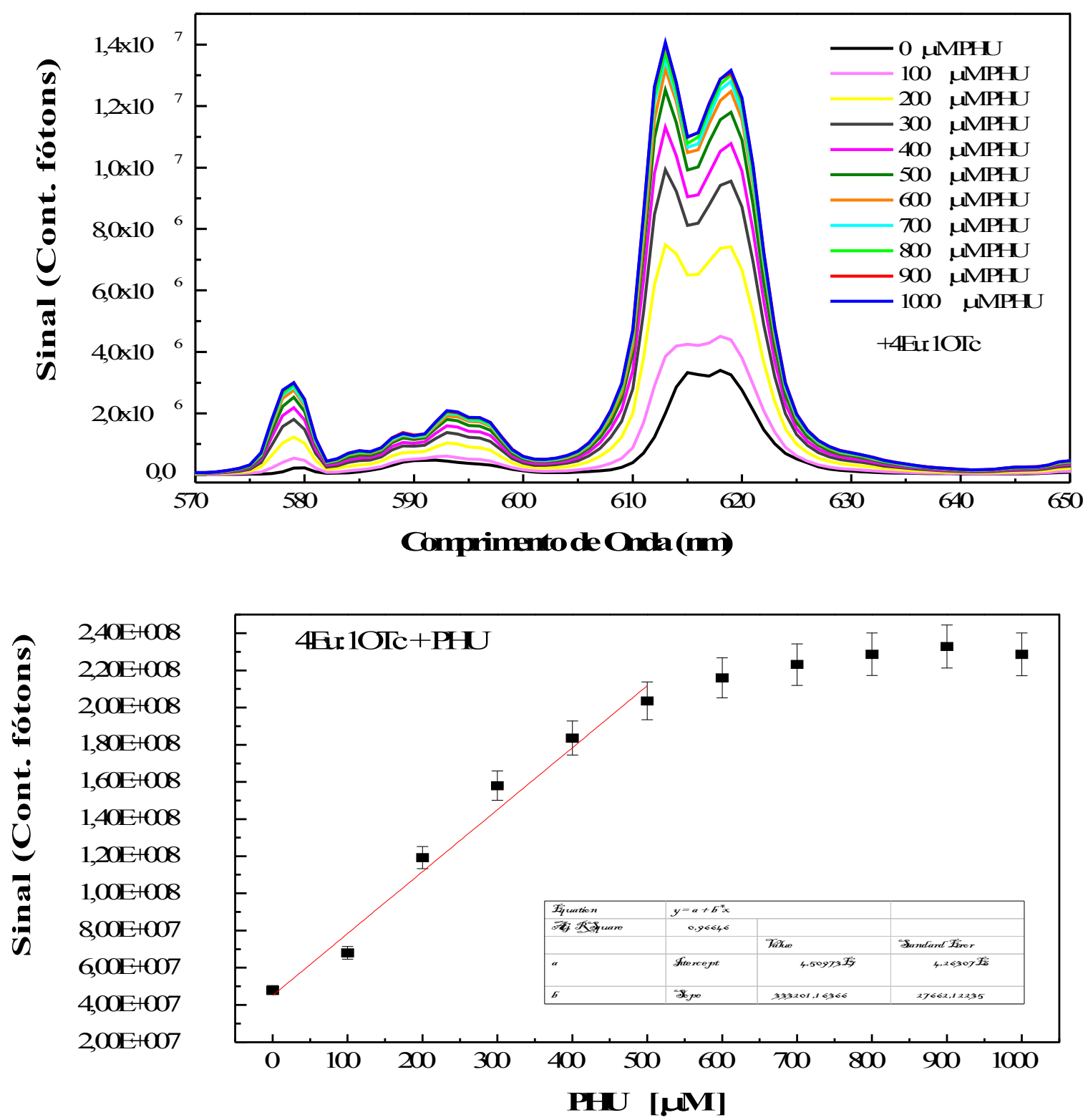

Figura 21 - (a) Espectro de emissão e (b) curva de calibração do complexo 4Eu:10Tc-PHU. 
Na Figura 22 é apresentado o espectro de emissão e curva de calibração do complexo EuCTc-PHU. A curva obtida possui linearidade entre 200 a $1000 \mu \mathrm{M}$. O aumento na emissão foi de 3 vezes em relação ao complexo sem PHU. O limite de detecção do complexo é de $0,08 \mathrm{mg} / \mathrm{mL}$.
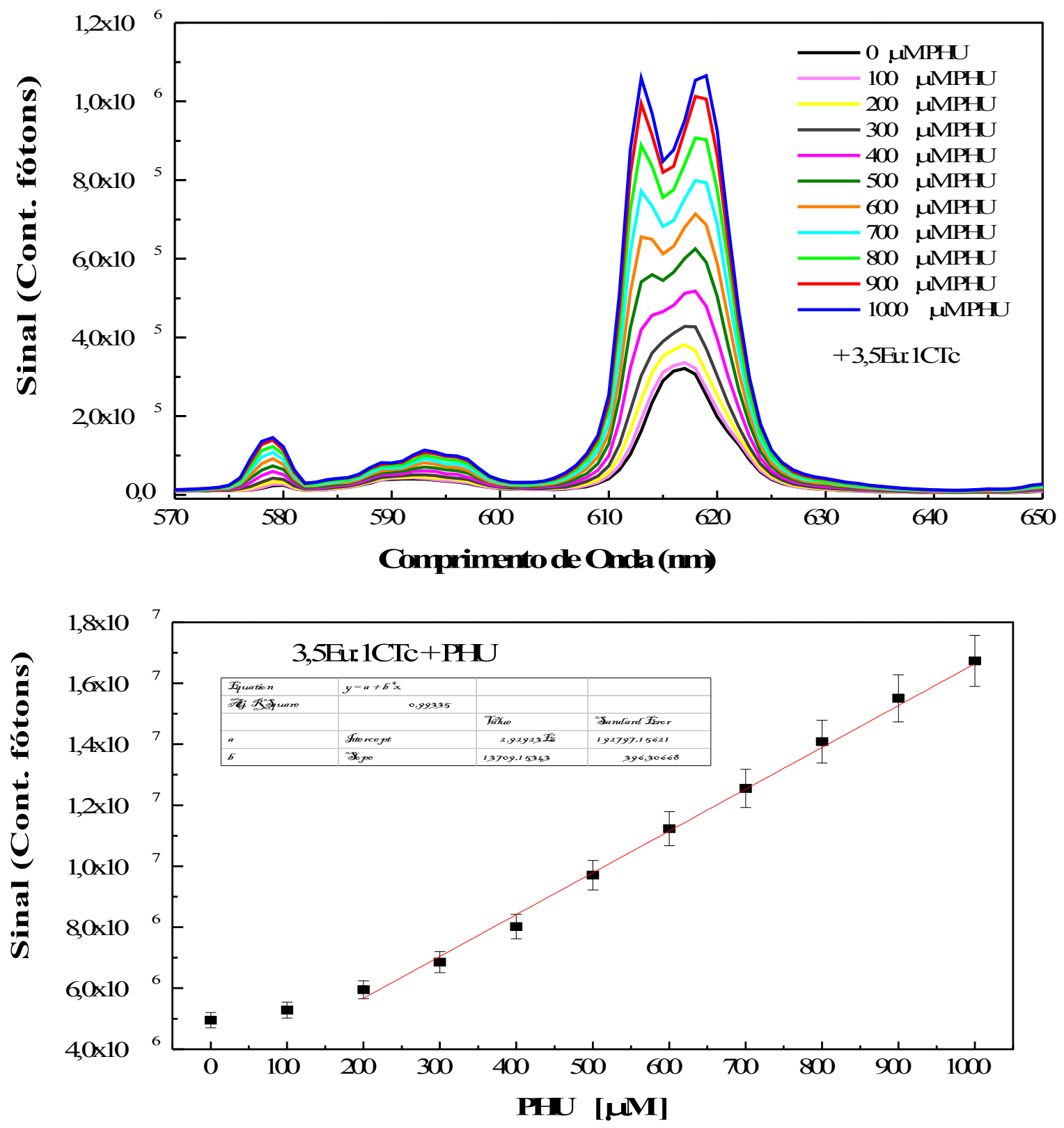

Figura 22 - (a) Espectro de emissão e (b) curva de calibração do complexo 3,5Eu:1CTc-PHU. 
A Figura 23 mostra o espectro de emissão e a curva de calibração do EuMTc-PHU. Pode-se observar que não houve alteração da luminescência com a presença de PHU.
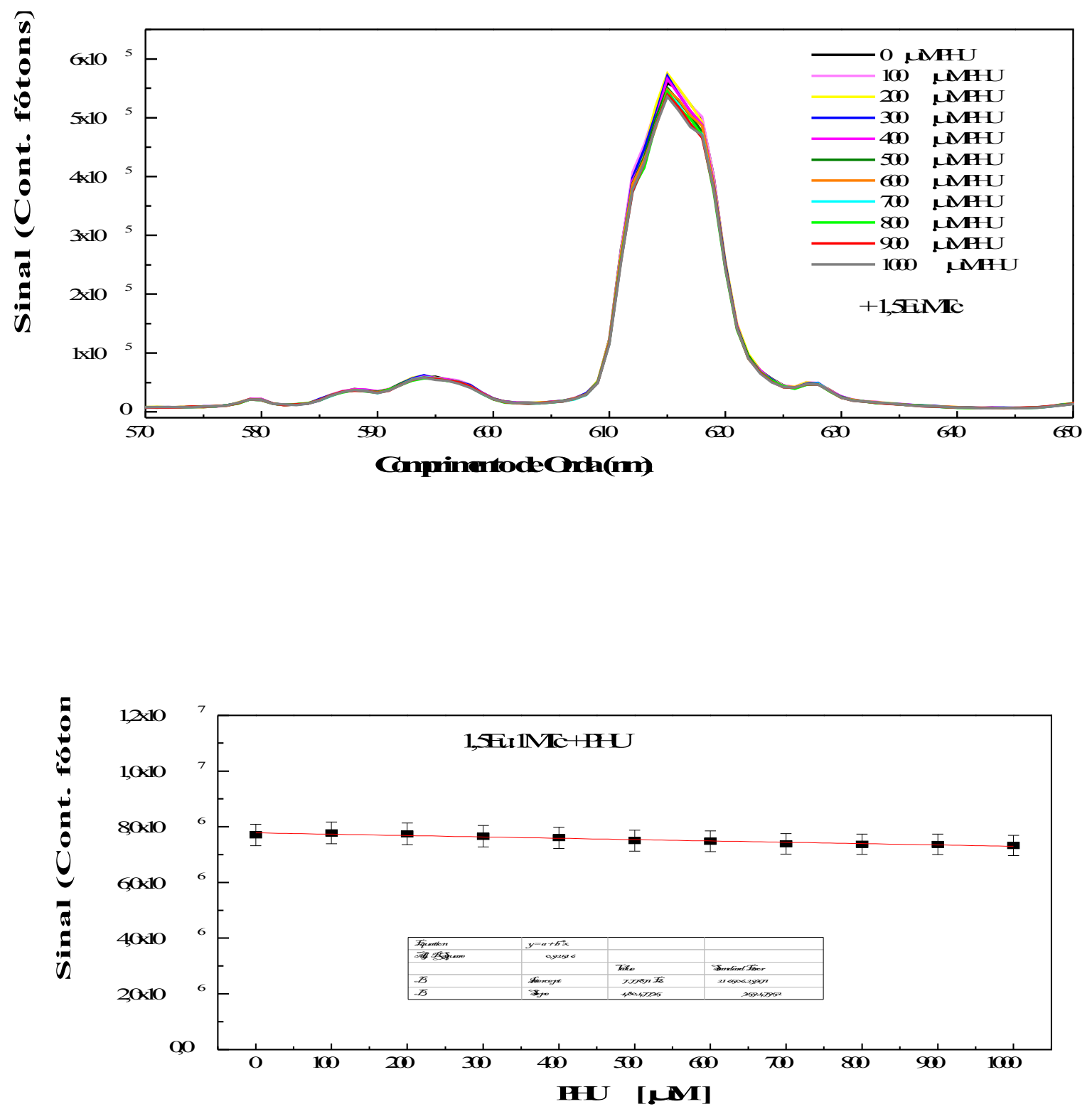

Figura 23 - (a) Espectro de emissão e (b) curva de calibração do complexo 1,5Eu:1MTc-PHU. 
Assim como nos experimentos com o peróxido de hidrogênio, há uma divisão da banda em torno de $615 \mathrm{~nm}$ sugerindo que o európio ocupa diferentes sítios na tetraciclina. Também há um considerável aumento na luminescência com a adição do peróxido de uréia (exceto nos estudos com o complexo európiometaciclina) provocado pela substituição de moléculas da água pelo $\mathrm{PHU}$.

\subsection{Tempo de Vida}

O tempo de vida é o tempo que o sistema demora a retornar ao estado fundamental, isto é, o tempo de transição ${ }^{5} \mathrm{D}_{0} \rightarrow{ }^{7} \mathrm{~F}_{2}$ do európio presente no complexo. Assim como os espectros de absorção óptica e de emissão, é uma importante medida para a caracterização dos complexos.

As medidas dos tempos de vida foram realizadas no fluorímetro Fluorolog 3 onde um pulso de luz excita a amostra. $O$ aparelho permite o controle de atrasos variáveis quando abre a janela de detecção, e por quanto tempo.

Geralmente sistemas complexos podem apresentar múltiplas espécies fluorescentes, e sendo assim, o perfil de decaimento da intensidade de fluorescência não pode ser ajustado por uma função exponencial simples. Dessa forma, foi ajustado por uma exponencial dupla: $y=y_{0}+A_{1} e^{\left(-t / \tau_{1}\right)}+A_{2} e^{\left(-t / \tau_{2}\right)}$, onde $\tau_{1}$ e $\tau_{2}$ são os tempos de decaimento ( $\mu \mathrm{s})$ e $A_{1}$ e $A_{2}$ são as amplitudes do sinal. No caso de decaimento com múltiplas exponenciais, a média do tempo de vida $\left(\tau_{\mathrm{av}}\right)$, é proporcional a área total abaixo da curva de decaimento da fluorescência, definida por :

$$
\tau_{a v}=\frac{\sum_{i} A_{i} \tau_{i}^{2}}{\sum_{i} A_{i} \tau_{i}}
$$


Os experimentos foram realizados considerando as razões molares de EuTCs que apresentaram maior intensidade de emissão na presença dos peróxidos de hidrogênio e uréia em nossos estudos (Tabela 8). No caso da tetraciclina a melhor proporção adotada, como dito anteriormente, foi a partir de artigos científicos que demonstram que a melhor razão molar da EuTc é 3:12,30.

Tabela 8 - Razão Molar das amostras de EuTC para estudo de tempo de vida.

\begin{tabular}{c|c|c}
\hline TC & $\begin{array}{c}\text { Razão Molar } \\
\text { EuTC com PH }\end{array}$ & $\begin{array}{c}\text { Razão Molar } \\
\text { EuTC com PHU }\end{array}$ \\
\hline \hline OTc & $4: 1$ & $4: 1$ \\
\hline CTc & $4: 1$ & $3.5: 1$ \\
\hline MTc & $2: 1$ & $1.5: 1$ \\
\hline Tc & $3: 1$ & $3: 1$ \\
\hline
\end{tabular}

Foram realizadas medidas do tempo de vida do európio em $615 \mathrm{~nm}$ para os complexos EuTc, EuCTc, EuMTc e EuOTc na ausência e na presença de $500 \mu \mathrm{M}$ de peróxido de hidrogênio ou peróxido de uréia. Os complexos EuTc e EuCTc foram excitados em $400 \mathrm{~nm}$, e os complexos EuMTc e EuOTc excitados em $390 \mathrm{~nm}$.

Comparando o tempo de vida de ambos os complexos EuTc e EuOTc com a adição de $\mathrm{PH}$ e $\mathrm{PHU}$, podemos notar um expressivo aumento no tempo de decaimento nas amostras que contêm peróxidos.

O complexo EuTc apresentou um tempo de vida de $34 \mu \mathrm{s}$, dobrando este valor

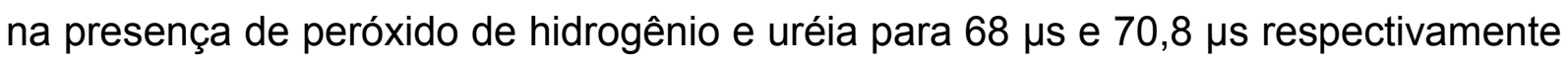
(Tabela 9 e Figura 24). 


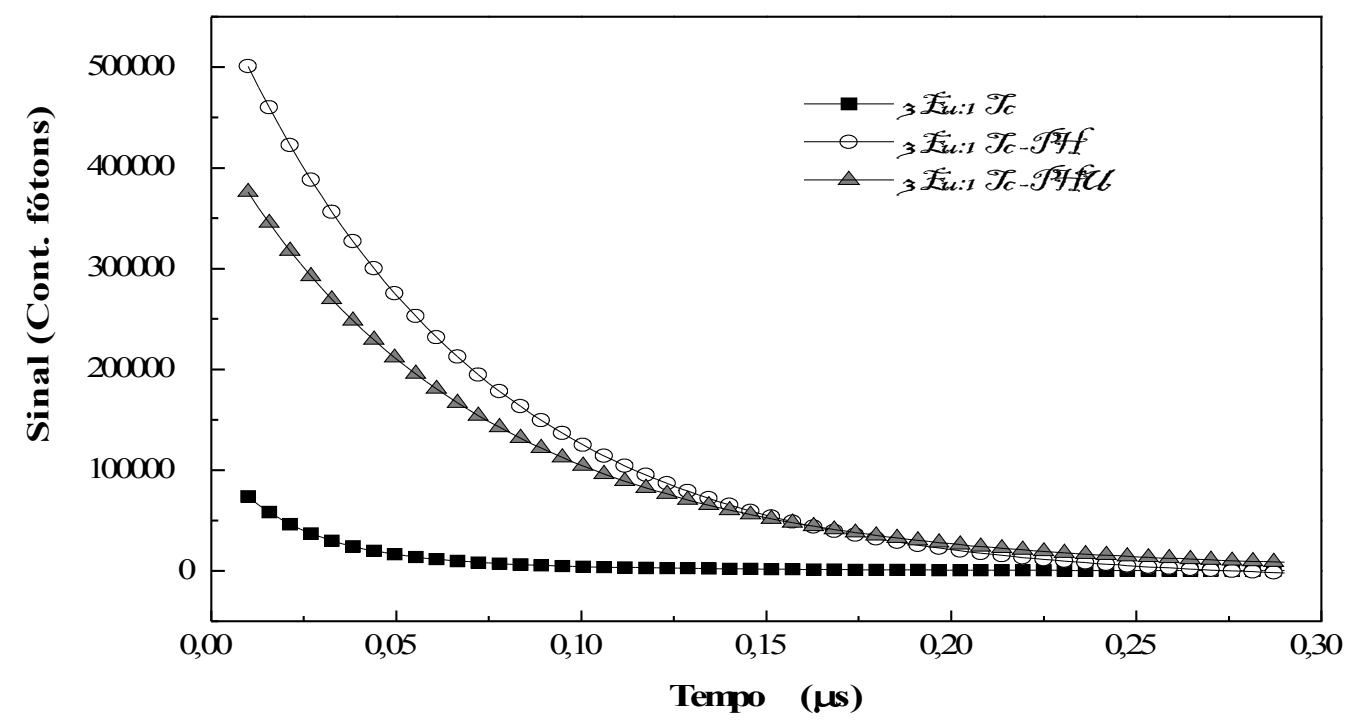

Figura 24 - Tempo de vida dos complexos EuTc, EuTc-PH e EuTc-PHU.

Tabela 9 - Parâmetros da dupla exponencial e tempo de vida dos complexos EuTc, EuTc-PH e EuTc-PHU.

\begin{tabular}{|c|c|c|c|c|}
\hline $\begin{array}{c}\text { Complexos } \\
\text { EuTc }\end{array}$ & Parâmetros & Valor & Erros & $\begin{array}{c}\tau \operatorname{av}(\mu \mathrm{s} \\
)\end{array}$ \\
\hline \multirow{4}{*}{ 3Eu:1Tc } & A1 & 17959,80474 & 1361,28738 & \multirow{4}{*}{34,40} \\
\hline & $\tau 1$ & 0,05979 & 0,00258 & \\
\hline & A2 & 95405,85839 & 1232,90573 & \\
\hline & $\tau 2$ & 0,02039 & $2,39 \mathrm{E}-04$ & \\
\hline \multirow{4}{*}{ 3Eu:1Tc-PH } & A1 & 295970,0749 & -- & \multirow{4}{*}{68,12} \\
\hline & $\tau 1$ & 0,06812 & 936,27005 & \\
\hline & $\mathrm{A} 2$ & 295970,0749 & -- & \\
\hline & $\tau 2$ & 0,06812 & 936,2752 & \\
\hline \multirow{4}{*}{ 3Eu:1Tc-PHU } & A1 & 419503,6848 & 4076,60778 & \multirow{4}{*}{70,87} \\
\hline & $\tau 1$ & 0,07143 & $6,29 \mathrm{E}-04$ & \\
\hline & $\mathrm{A} 2$ & 19039,70452 & 2999,26646 & \\
\hline & $\tau 2$ & 0,01581 & 0,00543 & \\
\hline
\end{tabular}


O EuOTc obteve um tempo de decaimento de $56 \mu$ s. Na presença de $\mathrm{PH}$ houve um aumento significativo para $95 \mu \mathrm{s}$ e complexado com PHU o aumento foi um pouco menor, $85 \mu$ s (Figura 25 eTabela 10).

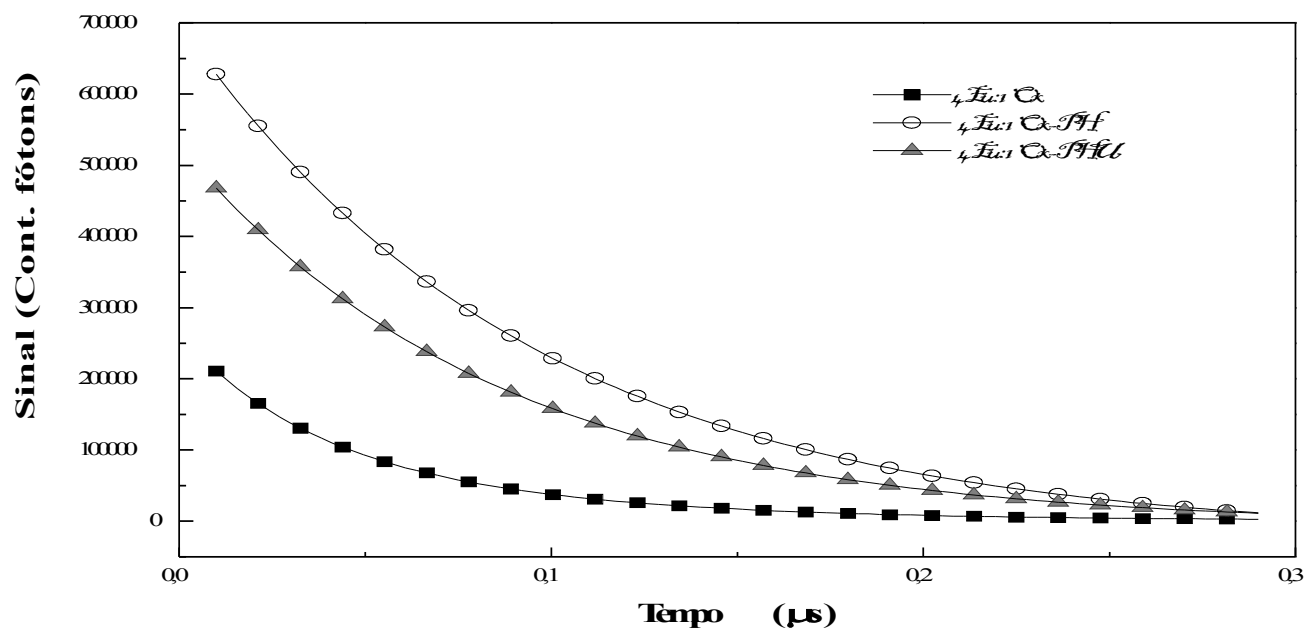

Figura 25 - Tempo de vida dos complexos EuOTc, EuOTc-PH e EuOTc-PHU.

Tabela 10 - Parâmetros da dupla exponencial e tempo de vida dos complexos EuOTc, EuOTc-PH e EuOTc-PHU.

\begin{tabular}{|c|c|c|c|c|}
\hline $\begin{array}{c}\text { Complexos } \\
\text { EuOTc }\end{array}$ & Parâmetros & Valor & Erros & $\tau \operatorname{tav}(\mu \mathrm{s})$ \\
\hline \multirow{4}{*}{ 4Eu:10Tc } & A1 & 118162,3517 & 13287,85149 & \multirow{4}{*}{56,62} \\
\hline & $\tau 1$ & 0,03069 & 0,00158 & \\
\hline & $\mathrm{A} 2$ & 145421,3542 & 13424,57947 & \\
\hline & $\tau 2$ & 0,06637 & 2,60E-03 & \\
\hline \multirow{4}{*}{ 4Eu:10Tc-PH } & $\mathrm{A} 1$ & 361436,2103 & -- & \multirow{4}{*}{95,13} \\
\hline & $\tau 1$ & 0,09513 & 27594,36244 & \\
\hline & $\mathrm{A} 2$ & 361436,2103 & -- & \\
\hline & $\tau 2$ & 0,09513 & 27594,37603 & \\
\hline \multirow{4}{*}{ 4Eu:10Tc-PHU } & A1 & 266855,5896 & $5,68 \mathrm{E}+10$ & \multirow{4}{*}{85,57} \\
\hline & $\tau 1$ & 0,08557 & $2,24 \mathrm{E}+03$ & \\
\hline & $\mathrm{A} 2$ & 266855,5896 & $5,68 \mathrm{E}+10$ & \\
\hline & $\tau 2$ & 0,08557 & 2238,38497 & \\
\hline
\end{tabular}

O complexo EuCTc apresentou um tempo de vida de aproximadamente $14 \mu \mathrm{s}$ e não houve variação significativa neste valor com a adição de ambos os peróxidos (Figura 26 e Tabela 11). 

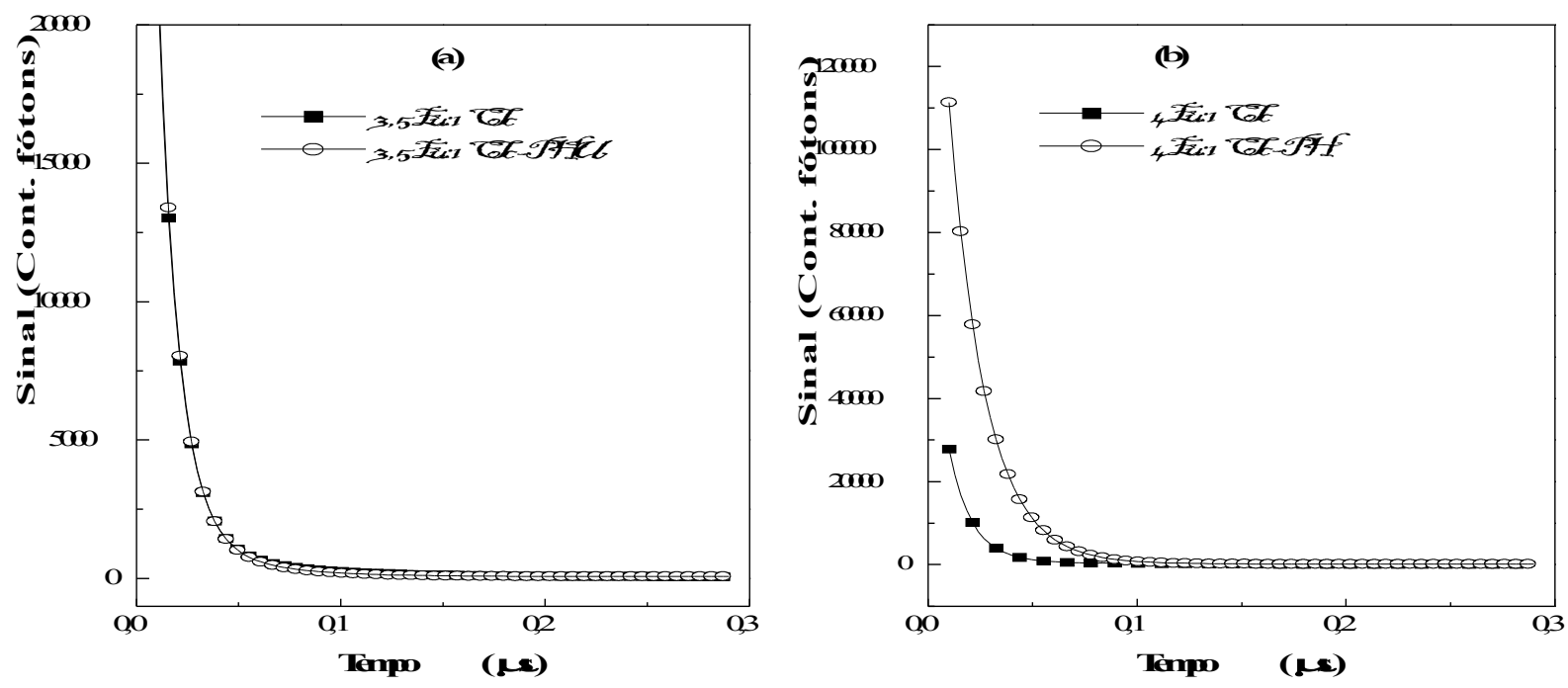

Figura 26 - Tempo de vida dos complexos EuCTc, (a) EuCTc-PHU e (b)EuCTc-PH.

Tabela 11 - Parâmetros da dupla exponencial e tempo de vida dos complexos EuCTc, EuCTc-PH e EuCTc-PHU.

\begin{tabular}{|c|c|c|c|c|}
\hline $\begin{array}{c}\text { Complexos } \\
\text { EuCTc }\end{array}$ & Parâmetros & Valor & Erros & $\tau \operatorname{av}(\mu \mathrm{s})$ \\
\hline \multirow{4}{*}{ 4Eu:1CTc } & $\mathrm{A} 1$ & 68489,77526 & 108,83675 & \multirow{4}{*}{14,50} \\
\hline & $\tau 1$ & 0,01065 & $4,22 \mathrm{E}-05$ & \\
\hline & A2 & 1269,88781 & 99,48436 & \\
\hline & $\tau 2$ & 0,05484 & 0,00341 & \\
\hline \multirow{4}{*}{ 4Eu:1CTc-PH } & A1 & 99184,43977 & $5,70 \mathrm{E}+10$ & \multirow{4}{*}{17,26} \\
\hline & $\tau 1$ & 0,01726 & 1152,10575 & \\
\hline & $\mathrm{A} 2$ & 99184,44086 & $5,70 \mathrm{E}+10$ & \\
\hline & $\tau 2$ & 0,01726 & $1,15 \mathrm{E}+03$ & \\
\hline \multirow{4}{*}{ 3,5Eu:1CTc } & A1 & 55412,20864 & $1,71 \mathrm{E}+02$ & \multirow{4}{*}{14,26} \\
\hline & $\tau 1$ & 0,01002 & $8,57 \mathrm{E}-05$ & \\
\hline & A2 & 1926,65618 & $2,01 \mathrm{E}+02$ & \\
\hline & $\tau 2$ & 0,04284 & 0,00276 & \\
\hline \multirow{4}{*}{$\begin{array}{c}\text { 3,5Eu:1CTc- } \\
\text { PHU }\end{array}$} & A1 & 57142,97607 & $2,76 \mathrm{E}+02$ & \multirow{4}{*}{12,83} \\
\hline & $\tau 1$ & 0,00985 & $1,78 \mathrm{E}-04$ & \\
\hline & $\mathrm{A} 2$ & 2718,83077 & $6,23 E+02$ & \\
\hline & $\tau 2$ & 0,03207 & 0,00336 & \\
\hline
\end{tabular}

O complexo EuMTc obteve o maior tempo de vida de todos os complexos estudados sem os peróxidos, $60 \mu$ s para a razão molar de 2Eu:1MTc e $74 \mu$ s para razão molar de 1,5Eu:1MTc. Na presença dos peróxidos houve uma diminuição no tempo de vida (Figura 27 e Tabela 12). 

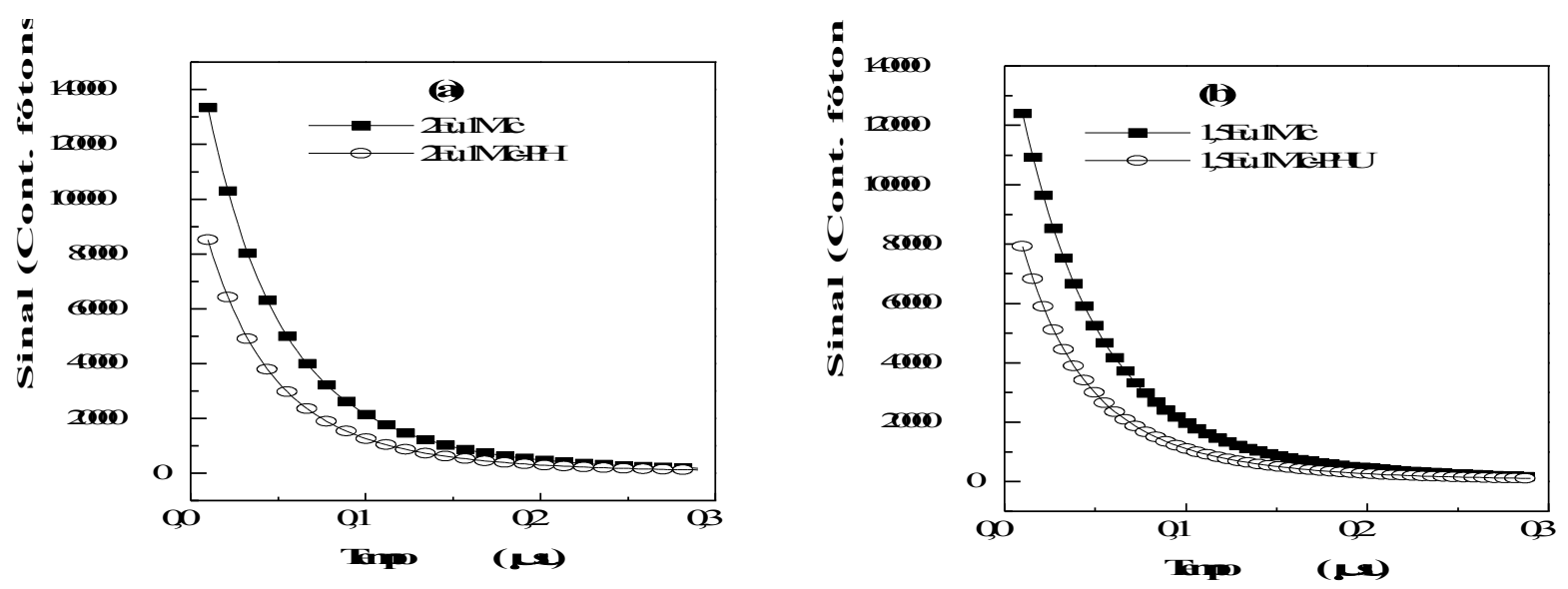

Figura 27 - Tempo de vida dos complexos EuMTc, (a) EuMTc-PH e (b) EuMTc-PHU.

Tabela 12- Parâmetros da dupla exponencial e tempo de vida dos complexos EuMTc, EuMTc-PH e EuMTc-PHU.

\begin{tabular}{|c|c|c|c|c|}
\hline $\begin{array}{l}\text { Complexos } \\
\text { EuMTc }\end{array}$ & Parâmetros & Valor & Erros & $\tau \operatorname{cav}(\mu \mathrm{s}$ \\
\hline \multirow{4}{*}{ 2Eu:1MTc } & A1 & 87851,8574 & 4217,77092 & \multirow{4}{*}{60,80} \\
\hline & $\tau 1$ & 0,03435 & $1,01 \mathrm{E}-03$ & \\
\hline & $\mathrm{A} 2$ & 20270,3167 & 4066,61632 & \\
\hline & $\tau 2$ & 0,1001 & 0,01572 & \\
\hline \multirow{4}{*}{ 2Eu:1MTc-PH } & A1 & 72578,6393 & $5,70 \mathrm{E}+03$ & \multirow{4}{*}{54,22} \\
\hline & $\tau 1$ & 0,03021 & 0,00128 & \\
\hline & $\mathrm{A} 2$ & 37370,17134 & $5,76 \mathrm{E}+03$ & \\
\hline & $\tau 2$ & 0,07342 & $5,86 \mathrm{E}-03$ & \\
\hline \multirow{4}{*}{ 1,5Eu:1MTc } & $\mathrm{A} 1$ & 17094,2358 & $3,03 E+03$ & \multirow{4}{*}{74,55} \\
\hline & $\tau 1$ & 0,1496 & $4,12 \mathrm{E}-02$ & \\
\hline & $\mathrm{A} 2$ & 139295,0583 & $3,79 \mathrm{E}+03$ & \\
\hline & $\tau 2$ & 0,04072 & $7,27 \mathrm{E}-04$ & \\
\hline \multirow{4}{*}{$\begin{array}{c}\text { 1,5Eu:1MTc- } \\
\text { PHU }\end{array}$} & $\mathrm{A} 1$ & 70179,78358 & $3,87 \mathrm{E}+03$ & \multirow{4}{*}{53,06} \\
\hline & $\tau 1$ & 0,02895 & $9,29 \mathrm{E}-04$ & \\
\hline & $\mathrm{A} 2$ & 33439,38579 & $3,92 \mathrm{E}+03$ & \\
\hline & $\tau 2$ & 0,07311 & 0,00465 & \\
\hline
\end{tabular}

Para o expressivo aumento no tempo de vida dos complexos na presença de peróxidos, sugerimos que as moléculas de água na solução contendo peróxidos são substituídas por estes. Com menor número de moléculas na vizinhança do íon európio, a transferência de energia para as moléculas de água é minimizada, e a 
energia é então praticamente mantida para o íon Eu3+, aumentando o tempo de vida e a intensidade da luminescência, resultando em um melhor rendimento quântico.

No complexo EuCTc não houve aumento no tempo de vida com a adição dos peróxidos possivelmente devido ao limite de detecção do equipamento, pois o ajuste fornece um valor irreal já que a medição realizada é o flash da lâmpada de xenônio do aparelho.

\subsection{Interferentes}

Para a análise da tolerância de compostos inorgânicos, preparamos amostras com interferentes em concentrações encontradas normalmente no sangue como ponto de partida para o estudo, e verificamos se tais componentes nestas concentrações de referência acarretam em aumento ou redução da fluorescência do európio em $615 \mathrm{~nm}$. Foram obtidas as relações de emissão para o complexo com PH ou PHU na presença dos interferentes. Os estudos de interferentes com a metaciclina foram desconsiderados devido aos resultados não expressivos na criação da curva de calibração.

\subsubsection{Complexos EuTC-PH}

Foram realizados experimentos para observar a interferência dos compostos inorgânicos nos complexos 3Eu:1Tc-PH (Figura 28), 4Eu:1OTc-PH (Figura 29) e 4Eu:1CTc-PH (Figura 30). Verifica-se que dentro das faixas de concentração encontradas normalmente no sangue, tais compostos não apresentam interferência significativa no sinal de emissão, pois considerando o aumento da luminescência em relação ao complexo európio-tetraciclina sem a presença de peróxido, a interferência torna-se irrelevante. 


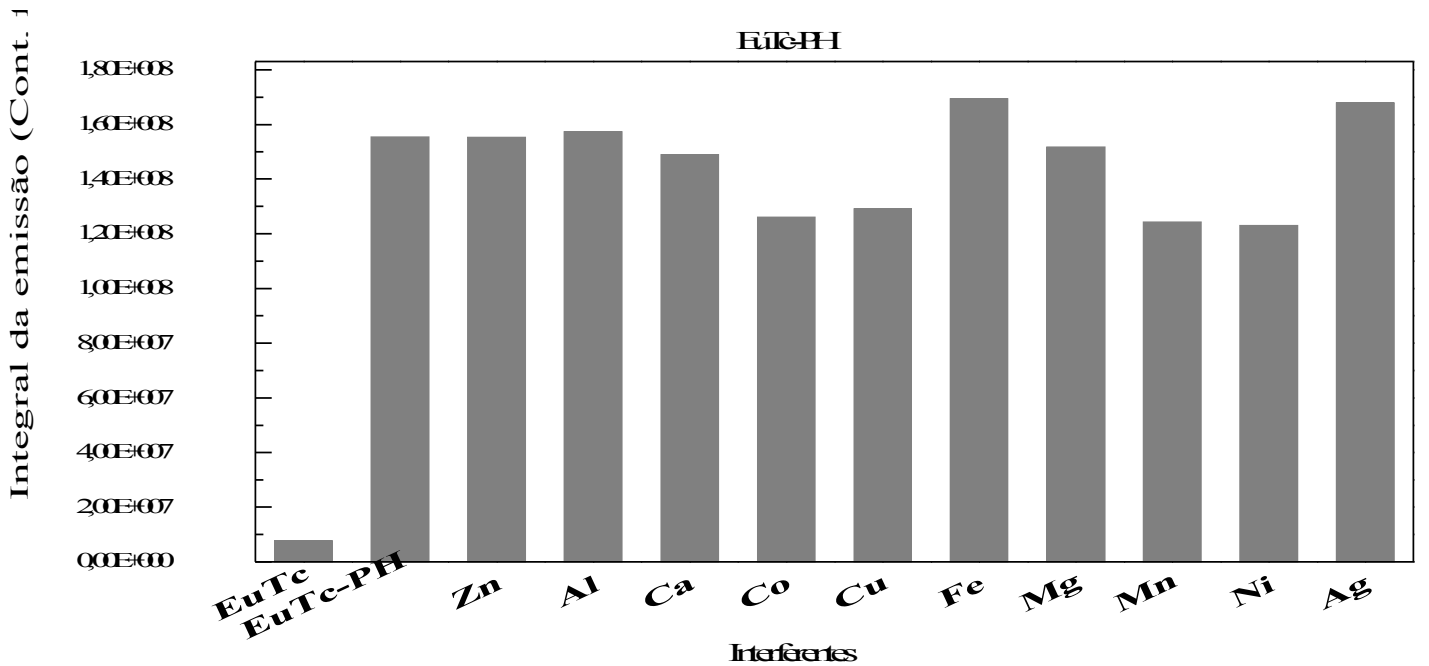

Figura 28 - Comparação da intensidade de emissão entre o os sinais dos complexos EuTc, EuTc-PH e dos complexos EuTc-PH na presença de interferentes.

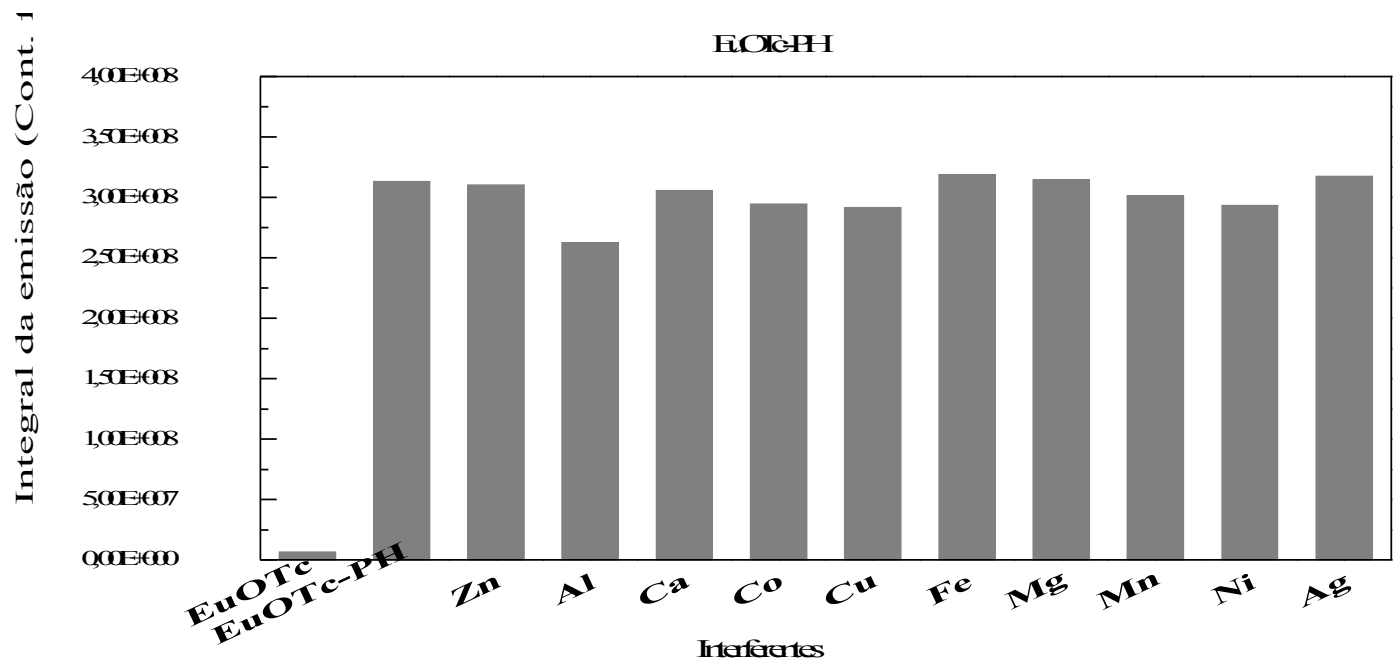

Figura 29 - Comparação da intensidade de emissão entre o os sinais dos complexos EuOTc, EuOTc-PH e dos complexos EuOTc-PH na presença de interferentes. 


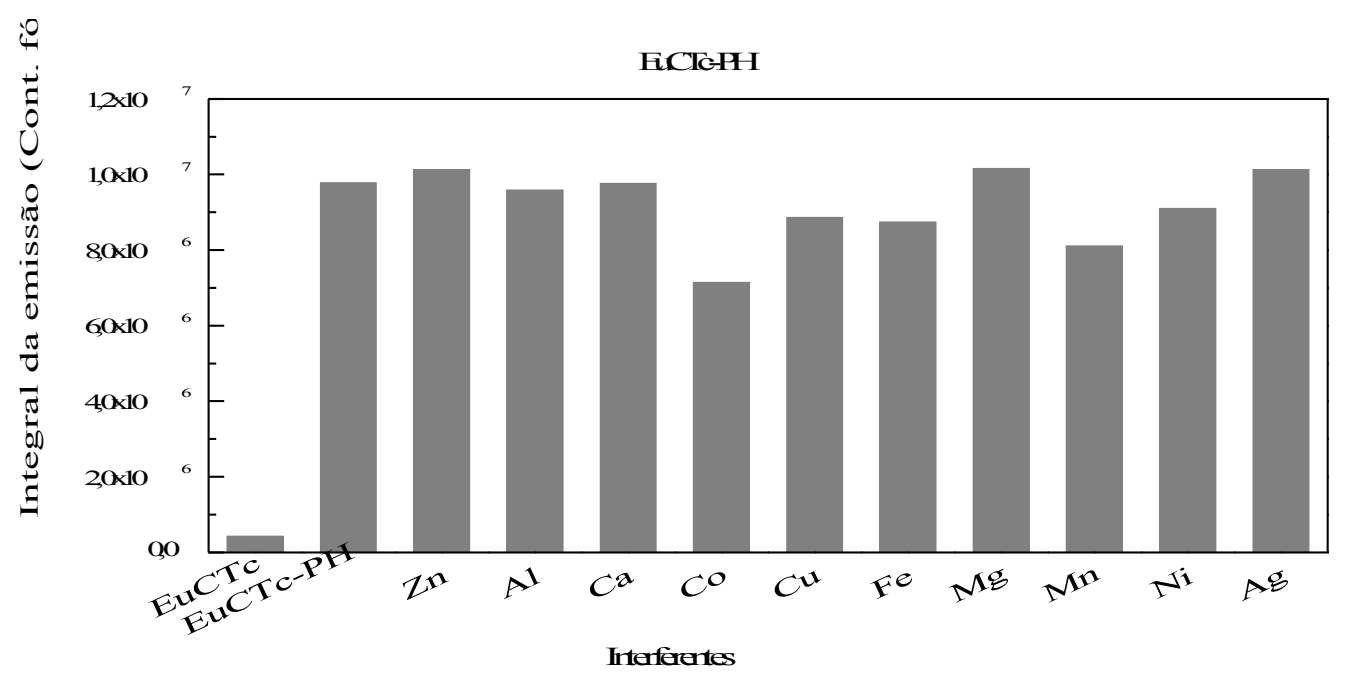

Figura 30 - Comparação da intensidade de emissão entre o os sinais dos complexos EuCTc, EuCTc-PH e dos complexos EuCTc-PH na presença de interferentes.

\subsubsection{Complexos EuTC-PHU}

Foram realizados experimentos para observar a interferência dos compostos inorgânicos nos complexos 3Eu:1Tc-PHU (Figura 31), 4Eu:10Tc-PHU (Figura 32) e 3,5Eu:1CTc-PHU (Figura 33). Assim como nos experimentos do peróxido de hidrogênio, existe uma pequena interferência na luminescência dos compostos inorgânicos estudados, que quando comparado ao aumento da emissão devido à presença do PHU torna-se irrisória. 


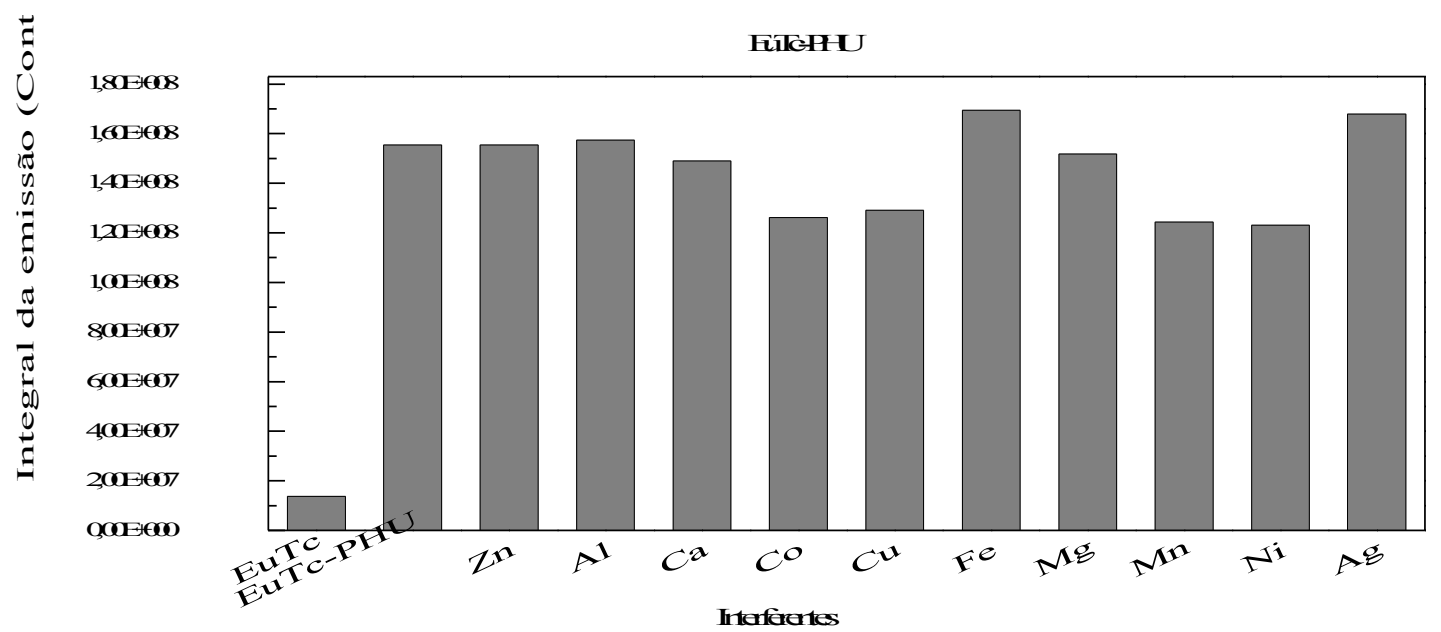

Figura 31 - Comparação da intensidade de emissão entre o os sinais dos complexos EuTc, EuTc-PHU e dos complexos EuTc-PHU na presença de interferentes.

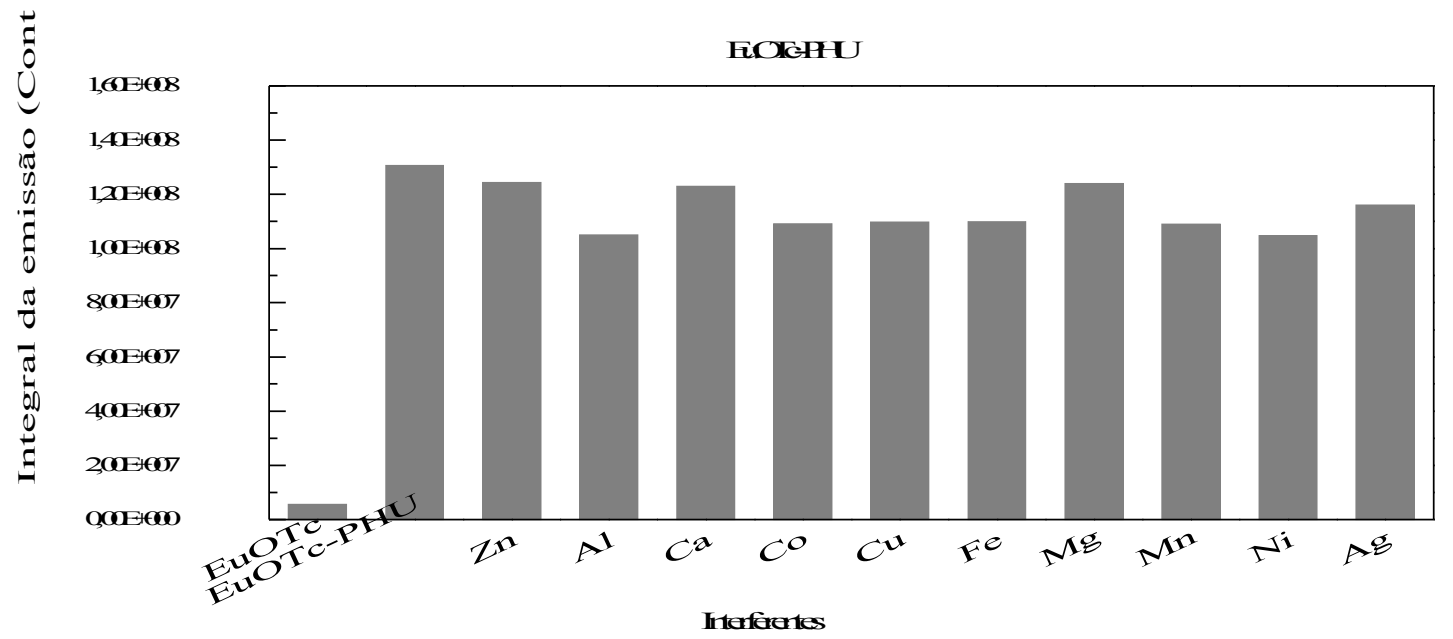

Figura 32 - Comparação da intensidade de emissão entre o os sinais dos complexos EuOTc, EuOTc-PHU e dos complexos EuOTc-PHU na presença de interferentes. 


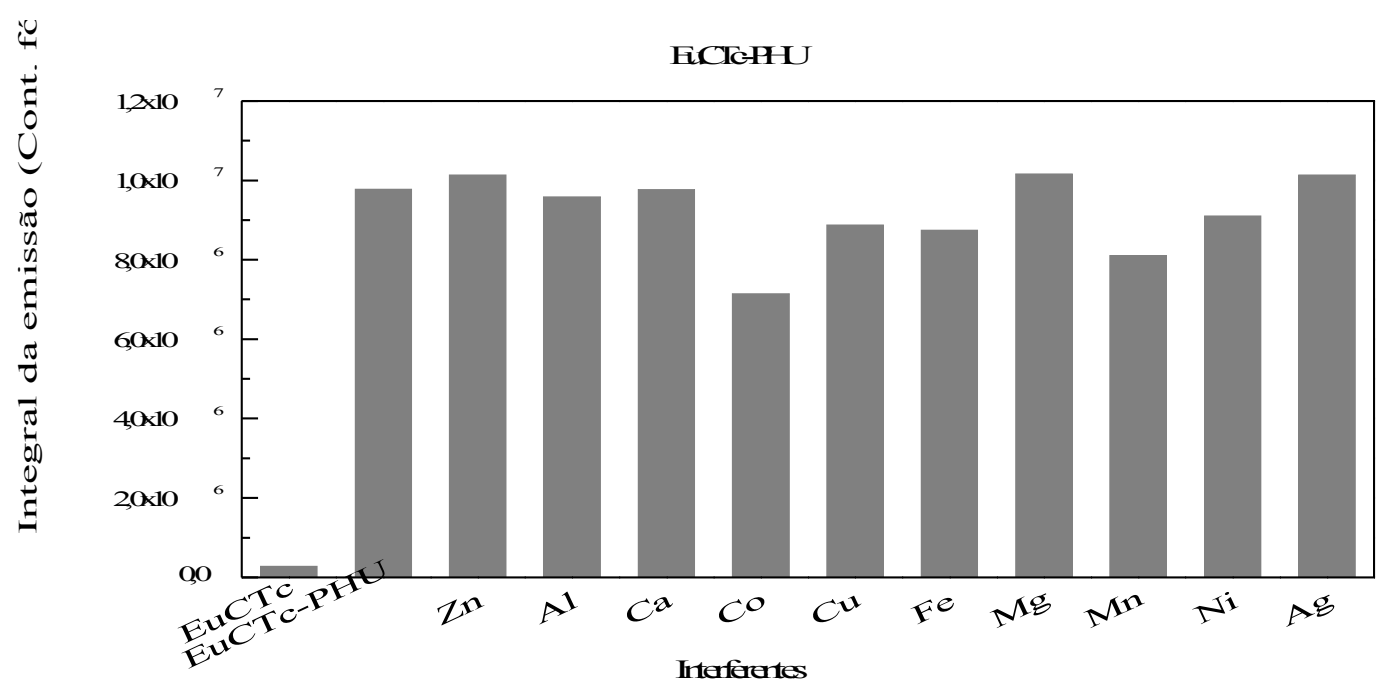

Figura 33 - Comparação da intensidade de emissão entre o os sinais dos complexos EuCTc, EuCTc-PHU e dos complexos EuCTc-PHU na presença de interferentes.

\subsection{Complexos EuTC com Glicose}

Sabendo que a glicose, na presença se GOx é quebrada em ácido glicônico e peróxido de hidrogênio, foram realizados estudos com o complexo európiotetraciclinas para a verificação do $\mathrm{PH}$ resultante e assim, indiretamente da glicose. Para este estudo foram utilizados os complexos 4Eu:1OTc-Glicose-Gox, 4Eu:1CTcGlicose-Gox e 3Eu:1Tc-Glicose-Gox para comparação dos resultados.

A Figura 34 mostra que a presença de apenas glicose com o complexo EuTC não promove aumento na intensidade da luminescência do mesmo.
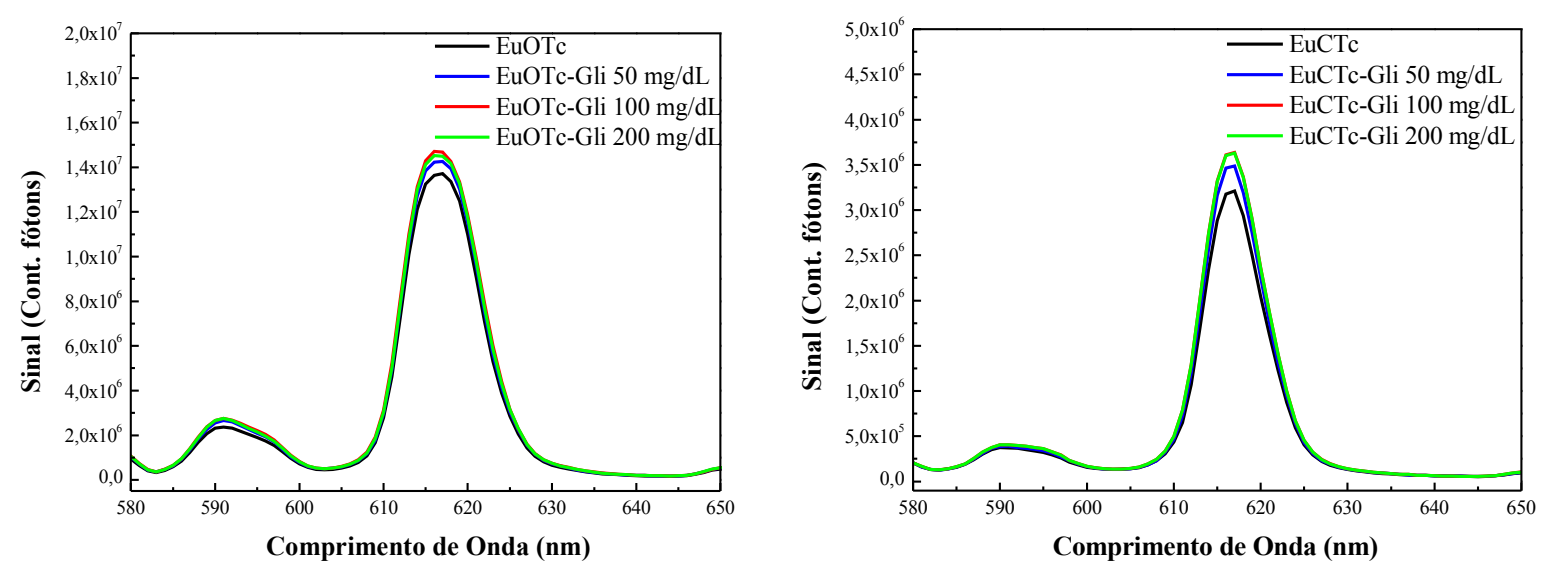

Figura 34 - Emissão dos complexos EuOTc e EuCTc, acrescidos de glicose nas concentrações de 50, 100 e 200 mg/dL. 
Nos experimentos seguintes foi adicionado Gox ao complexo EuTCGlicose para a quebra da molécula de açúcar e formação de peróxido de hidrogênio. Foi utilizada a concentração de $5 \mu \mathrm{L}$ de Gox, pois para $225 \mathrm{mg} / \mathrm{dL}$ de glicose maiores quantidades de Gox não mostraram diferença no aumento na luminescência e portanto na formação de $\mathrm{PH}$. Observa-se que para todas as tetraciclinas estudadas houve um aumento na emissão do complexo.

A Figura 35 mostra a emissão e curva de calibração do complexo EuTcGlicose-Gox. Houve um aumento de 4,7 vezes na emissão com linearidade de 0 à $100 \mathrm{mg} / \mathrm{dL}$ de glicose. O limite de detecção foi de 0,29 mg/dL. 

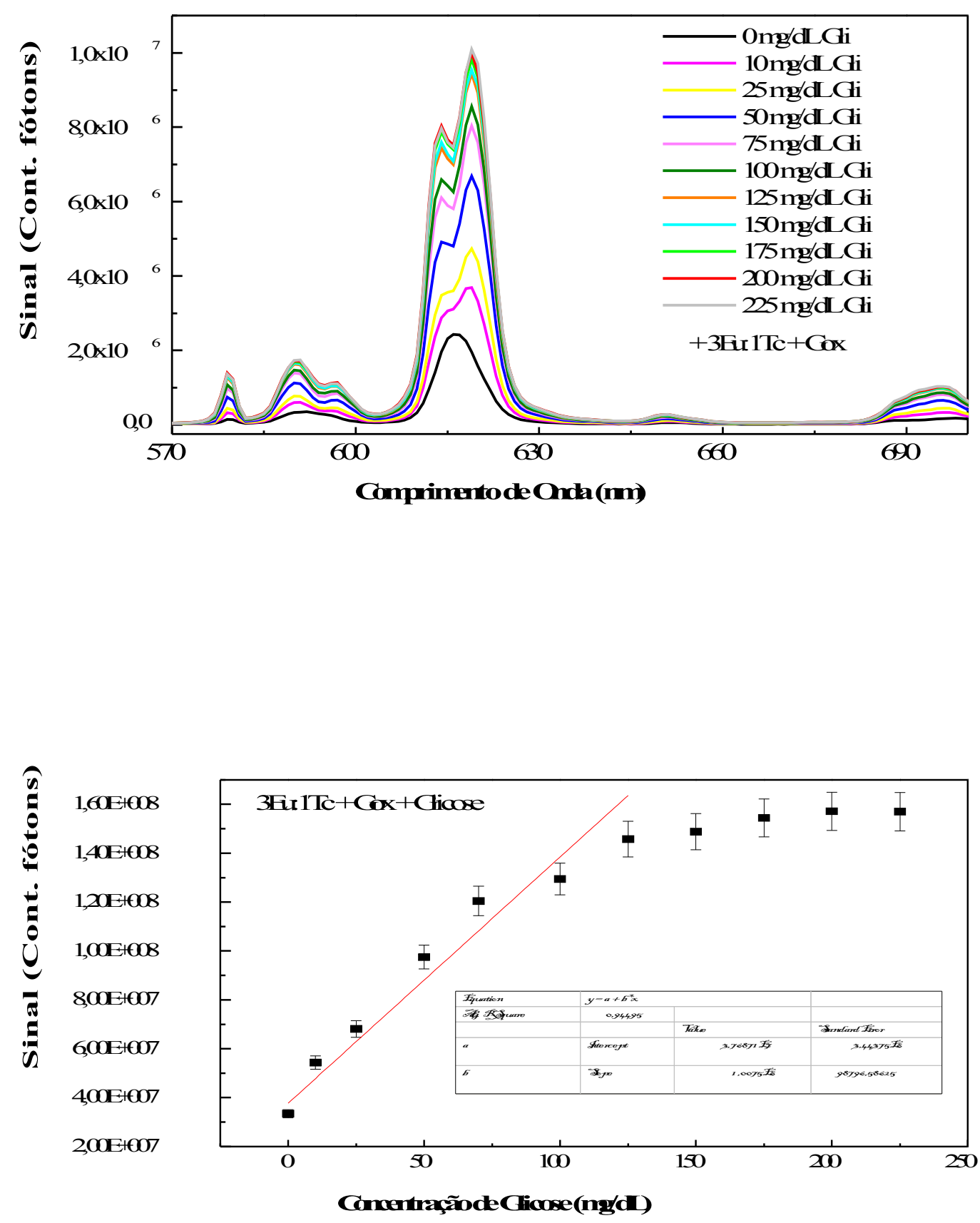

Figura 35 - Emissão e curva de calibração dos complexos EuTc-Glicose-Gox, variando a concentração de glicose nas amostras. Excitação em $400 \mathrm{~nm}$.

O complexo EuOTc-Glicose-Gox apresentou um aumento de 3,1 em em relação à amostra sem glicose (Figura 36). A faixa de linearidade foi de 10 a 125 $\mathrm{mg} / \mathrm{dL}$ de glicose e o limite de detecção obtido foi $0,246 \mathrm{mg} / \mathrm{dL}$. 

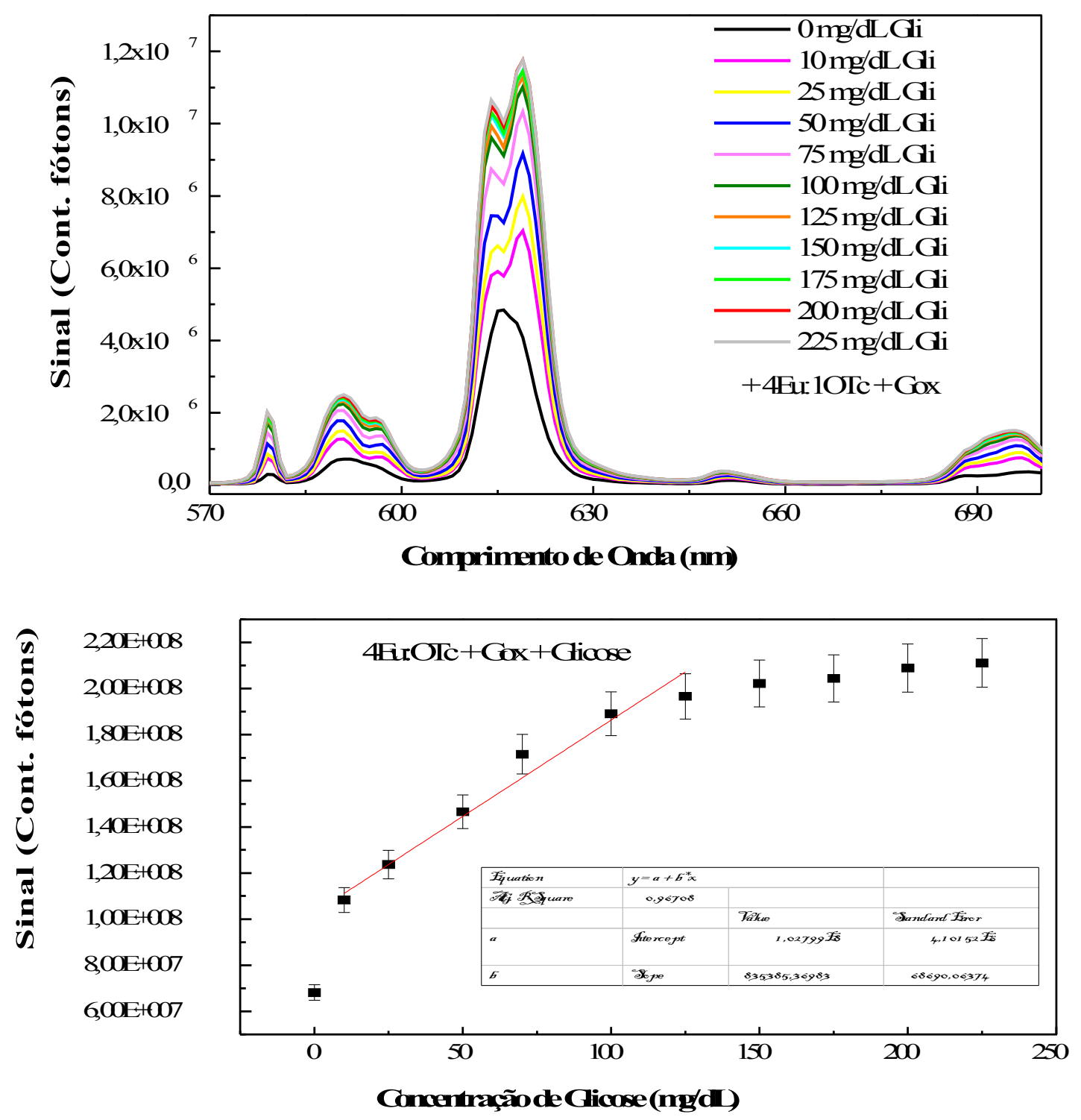

Figura 36 - Emissão e curva de calibração dos complexos EuOTc-Glicose-Gox, variando a concentração de glicose nas amostras. Excitação em 390 nm.

A Figura 37 mostra a emissão e curva de calibração do complexo EuCTcGlicose-Gox. Houve um aumento de 4,2 vezes na luminescência em relação à 
amostra sem glicose com linearidade de 10 a $125 \mathrm{mg} / \mathrm{dL}$ de glicose. $O$ limite de detecção foi de $0,22 \mathrm{mg} / \mathrm{dL}$.
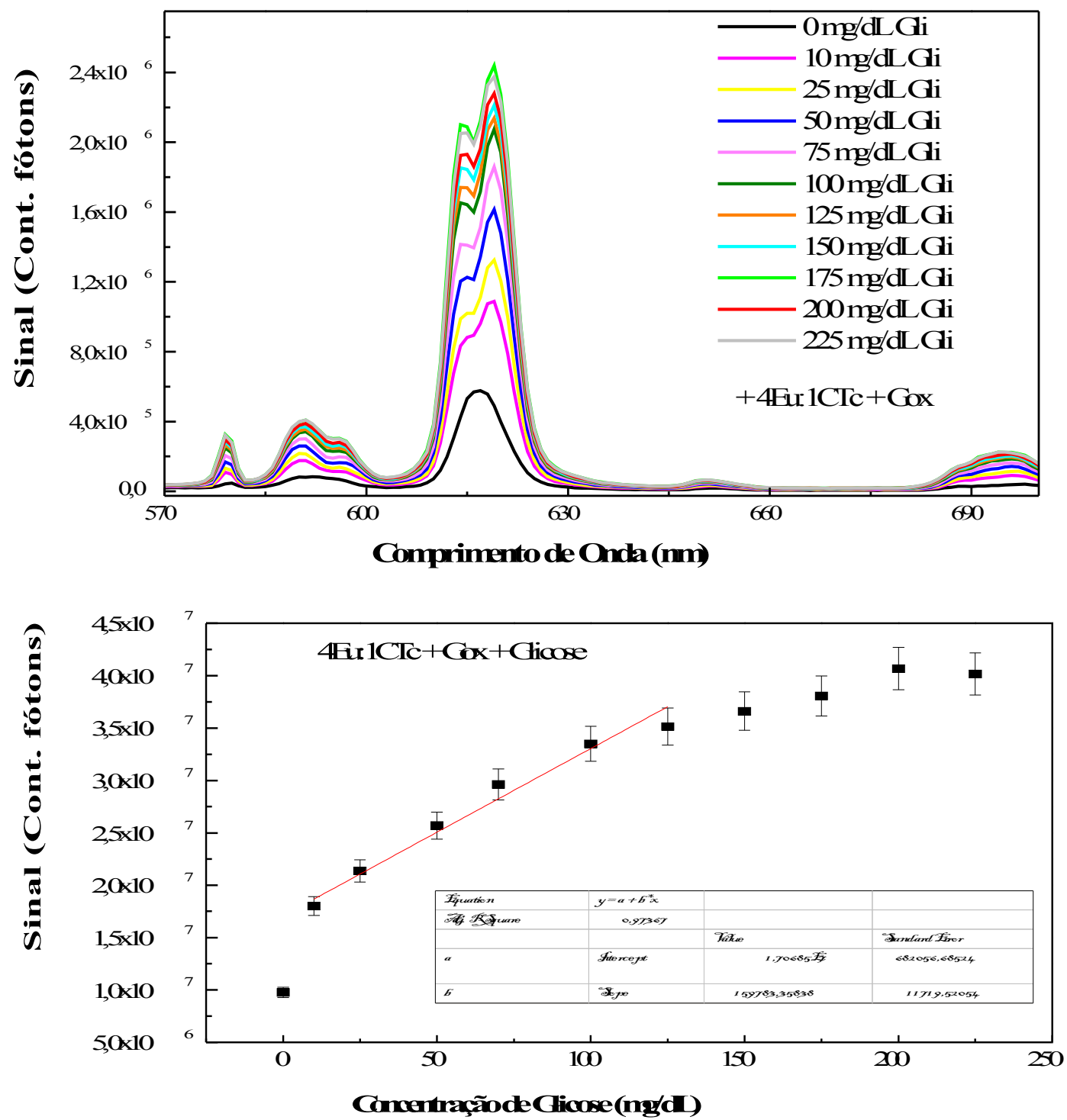

Figura 37 - Emissão e curva de calibração dos complexos EuCTc-Glicose-Gox, variando a concentração de glicose nas amostras. Excitação em 390 nm.

Foram também realizados estudos do tempo de vida com os complexos: EuTc-Glicose-Gox (Figura 38 e Tabela 13), EuCTc-Glicose-Gox (Figura 39 e Tabela 14) , EuOTc-Glicose-Gox (Figura 40 e Tabela 15). Todos apresentaram um aumento no tempo de vida. 


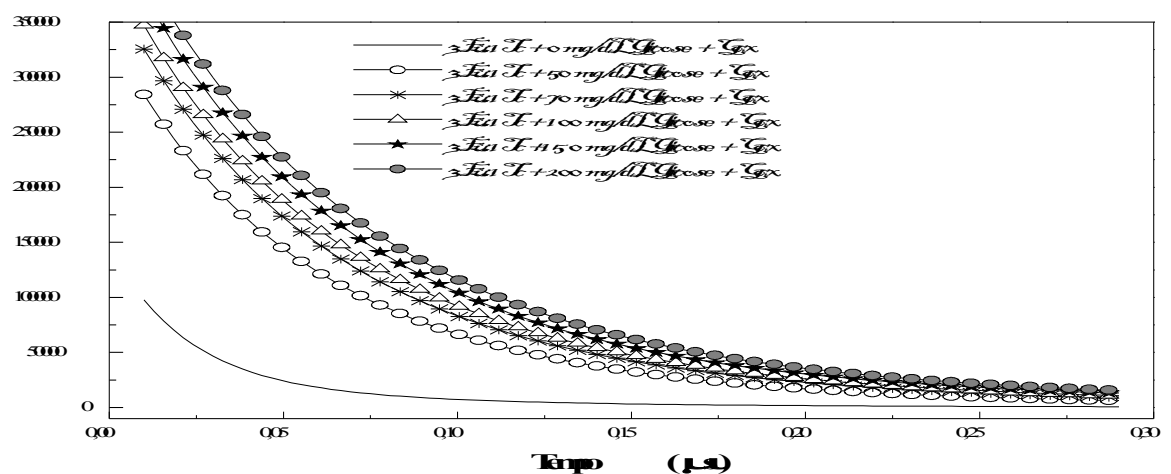

Figura 38 - Tempo de vida do complexo EuTc com diferentes concentrações de Glicose acrescidas de Gox.

Tabela 13 - Parâmetros da dupla exponencial e tempo de vida do complexo EuTc com diferentes concentrações de Glicose acrescidas de Gox.

\begin{tabular}{|c|c|c|c|c|}
\hline Complexo EuTc & Parâmetros & Valor & Erros & $\tau \operatorname{av}(\mu \mathrm{s})$ \\
\hline \multirow{4}{*}{$\begin{array}{c}\text { 3Eu:1Tc + } \\
0 \mathrm{mg} / \mathrm{dL} \text { Glicose }+ \\
\text { Gox }\end{array}$} & $\mathrm{A} 1$ & 121550,65703 & 1193,59368 & \multirow{4}{*}{40,93} \\
\hline & $\tau 1$ & 0,02158 & 0,00021 & \\
\hline & $\mathrm{A} 2$ & 24195,68202 & 1304,33551 & \\
\hline & $\tau 2$ & 0,07064 & 0,00265 & \\
\hline \multirow{4}{*}{$\begin{array}{c}\text { 3Eu:1Tc + } \\
50 \text { mg/dL Glicose } \\
+ \text { Gox }\end{array}$} & A1 & 109827,03652 & 17190,91484 & \multirow{4}{*}{65,87} \\
\hline & $\tau 1$ & 0,03599 & 0,00218 & \\
\hline & $\mathrm{A} 2$ & 228310,65272 & 17184,86842 & \\
\hline & $\tau 2$ & 0,07297 & 0,00220 & \\
\hline \multirow{4}{*}{$\begin{array}{c}\text { 3Eu:1Tc + } \\
70 \text { mg/dL Glicose + } \\
\text { Gox }\end{array}$} & A1 & 297660,40431 & 33852,44129 & \multirow{4}{*}{67,74} \\
\hline & $\tau 1$ & 0,07218 & 0,00335 & \\
\hline & $\mathrm{A} 2$ & 83103,63878 & 33824,85897 & \\
\hline & $\tau 2$ & 0,03511 & 0,00571 & \\
\hline \multirow{4}{*}{$\begin{array}{c}\text { 3Eu:1Tc + } \\
100 \mathrm{mg} / \mathrm{dL} \text { Glicose } \\
+ \text { Gox }\end{array}$} & A1 & 332630,06093 & 31674,35235 & \multirow{4}{*}{69,33} \\
\hline & $\tau 1$ & 0,07286 & 0,00311 & \\
\hline & $\mathrm{A} 2$ & 71109,08663 & 31586,01998 & \\
\hline & $\tau 2$ & 0,03334 & 0,00661 & \\
\hline \multirow{4}{*}{$\begin{array}{c}\text { 3Eu:1Tc + } \\
150 \text { mg/dL Glicose } \\
+ \text { Gox }\end{array}$} & A1 & 395877,62839 & 19573,03805 & \multirow{4}{*}{69,83} \\
\hline & $\tau 1$ & 0,07132 & 0,00197 & \\
\hline & $\mathrm{A} 2$ & 36073,95718 & 19108,45165 & \\
\hline & $\tau 2$ & 0,02721 & 0,00913 & \\
\hline \multirow{4}{*}{$\begin{array}{c}\text { 3Eu:1Tc + } \\
200 \text { mg/dL Glicose } \\
+ \text { Gox }\end{array}$} & A1 & 88095,33658 & 71256,06906 & \multirow{4}{*}{74,09} \\
\hline & $\tau 1$ & 0,04264 & 0,01071 & \\
\hline & $\mathrm{A} 2$ & 364994,19201 & 70906,74260 & \\
\hline & $\tau 2$ & 0,07823 & 0,00528 & \\
\hline
\end{tabular}




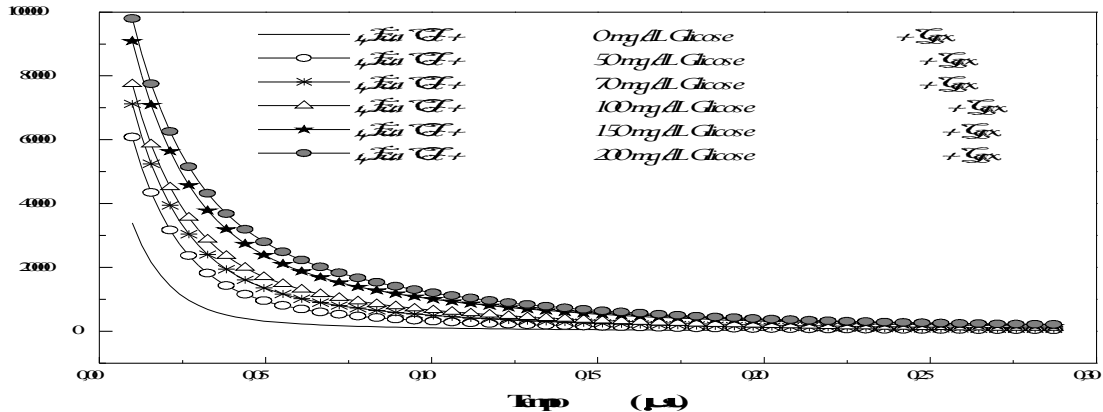

Figura 39 - Tempo de vida do complexo EuCTc com diferentes concentrações de Glicose acrescidas de Gox.

Tabela 14 - Parâmetros da dupla exponencial e tempo de vida do complexo EuCTc com diferentes concentrações de Glicose acrescidas de Gox.

\begin{tabular}{|c|c|c|c|c|}
\hline Complexo EuCTc & Parâmetros & Valor & Erros & $\tau_{\mathrm{av}}(\mu \mathrm{s})$ \\
\hline \multirow{4}{*}{$\begin{array}{c}\text { 4Eu: } 1 \mathrm{CTc}+0 \\
\mathrm{mg} / \mathrm{dL} \text { Glicose }+ \\
\text { Gox }\end{array}$} & $\mathrm{A} 1$ & 72832,03257 & 198,45849 & \multirow{4}{*}{23,04} \\
\hline & $\tau 1$ & 0,01081 & 0,00008 & \\
\hline & $\mathrm{A} 2$ & 5864,51364 & 206,69803 & \\
\hline & $\tau 2$ & 0,05365 & 0,00145 & \\
\hline \multirow{4}{*}{$\begin{array}{c}\text { 4Eu: } 1 \mathrm{CTc}+50 \\
\mathrm{mg} / \mathrm{dL} \text { Glicose }+ \\
\text { Gox }\end{array}$} & A1 & 15697,85126 & 520,36288 & \multirow{4}{*}{31,48} \\
\hline & $\tau 1$ & 0,05791 & 0,00143 & \\
\hline & $\mathrm{A} 2$ & 98849,54040 & 331,70868 & \\
\hline & $\tau 2$ & 0,01355 & 0,00012 & \\
\hline \multirow{4}{*}{$\begin{array}{c}\text { 4Eu:1CTc }+70 \\
\mathrm{mg} / \mathrm{dL} \text { Glicose }+ \\
\text { Gox }\end{array}$} & $\mathrm{A} 1$ & 105213,99684 & 639,21869 & \multirow{4}{*}{36,66} \\
\hline & $\tau 1$ & 0,01407 & 0,00022 & \\
\hline & $\mathrm{A} 2$ & 22347,84784 & 968,24062 & \\
\hline & $\tau 2$ & 0,06115 & 0,00208 & \\
\hline \multirow{4}{*}{$\begin{array}{c}\text { 4Eu:1CTc }+100 \\
\mathrm{mg} / \mathrm{dL} \text { Glicose + } \\
\text { Gox }\end{array}$} & $\mathrm{A} 1$ & 27292,34207 & 1047,50260 & \multirow{4}{*}{41,08} \\
\hline & $\tau 1$ & 0,06431 & 0,00201 & \\
\hline & $\mathrm{A} 2$ & 104849,44526 & 722,82028 & \\
\hline & $\tau 2$ & 0,01478 & 0,00024 & \\
\hline \multirow{4}{*}{$\begin{array}{c}\text { 4Eu:1CTc }+150 \\
\text { mg/dL Glicose + } \\
\text { Gox }\end{array}$} & A1 & 109849,01646 & 606,36756 & \multirow{4}{*}{48,94} \\
\hline & $\tau 1$ & 0,01573 & 0,00019 & \\
\hline & $\mathrm{A} 2$ & 36639,60353 & 828,09009 & \\
\hline & $\tau 2$ & 0,07101 & 0,00145 & \\
\hline \multirow{4}{*}{$\begin{array}{c}\text { 4Eu:1CTc }+200 \\
\mathrm{mg} / \mathrm{dL} \text { Glicose }+ \\
\text { Gox }\end{array}$} & A1 & 108472,36126 & 1411,83128 & \multirow{4}{*}{49,97} \\
\hline & $\tau 1$ & 0,01580 & 0,00043 & \\
\hline & $\mathrm{A} 2$ & 44996,56435 & 1923,16881 & \\
\hline & $\tau 2$ & 0,06888 & 0,00253 & \\
\hline
\end{tabular}




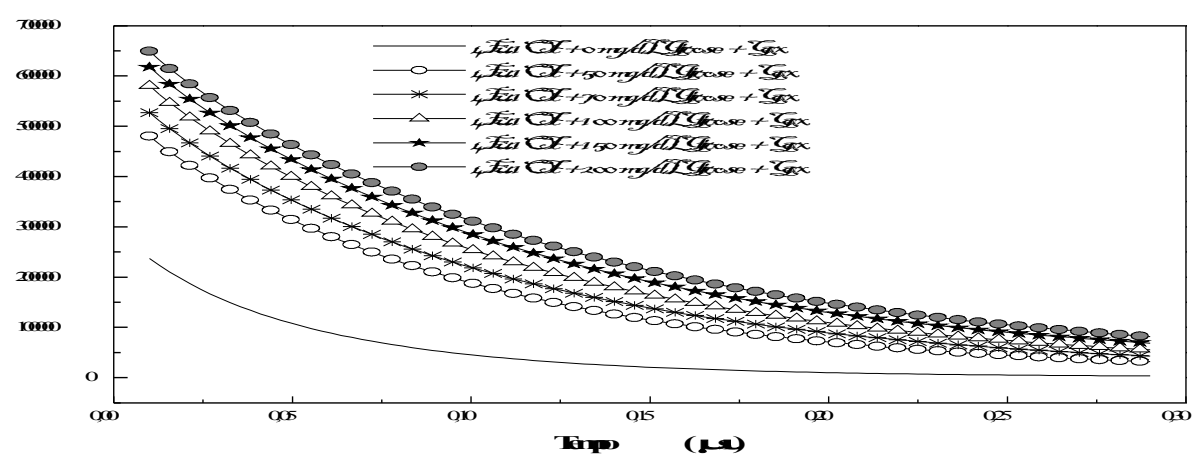

Figura 40 - Tempo de vida do complexo EuOTc com diferentes concentrações de Glicose acrescidas de Gox.

Tabela 15 - Parâmetros da dupla exponencial e tempo de vida do complexo EuOTc com diferentes concentrações de Glicose acrescidas de Gox.

\begin{tabular}{|c|c|c|c|c|}
\hline Complexo EuOTc & Parâmetros & Valor & Erros & $\tau_{\mathrm{av}}(\mu \mathrm{s})$ \\
\hline \multirow{4}{*}{$\begin{array}{c}\text { 4Eu:10Tc }+0 \\
\text { mg/dL Glicose + } \\
\text { Gox }\end{array}$} & $\mathrm{A} 1$ & 92805,64026 & 7640,52093 & \multirow{4}{*}{57,83} \\
\hline & $\tau 1$ & 0,02675 & 0,00124 & \\
\hline & $\mathrm{A} 2$ & 200902,32308 & 7841,81219 & \\
\hline & $\tau 2$ & 0,06385 & 0,00118 & \\
\hline \multirow{4}{*}{$\begin{array}{c}\text { 4Eu:10Tc }+50 \\
\text { mg/dL Glicose + } \\
\text { Gox }\end{array}$} & A1 & 34493,90438 & 11189,90736 & \multirow{4}{*}{95,31} \\
\hline & $\tau 1$ & 0,00716 & 0,00195 & \\
\hline & $\mathrm{A} 2$ & 516263,77842 & 595,05360 & \\
\hline & $\tau 2$ & 0,09576 & 0,00023 & \\
\hline \multirow{4}{*}{$\begin{array}{c}\text { 4Eu:10Tc }+70 \\
\text { mg/dL Glicose + } \\
\text { Gox }\end{array}$} & $\mathrm{A} 1$ & 25886,81210 & 2044,08315 & \multirow{4}{*}{101,42} \\
\hline & $\tau 1$ & 0,01236 & 0,00224 & \\
\hline & $\mathrm{A} 2$ & 556456,83466 & 1174,14417 & \\
\hline & $\tau 2$ & 0,10193 & 0,00042 & \\
\hline \multirow{4}{*}{$\begin{array}{c}\text { 4Eu:10Tc }+100 \\
\mathrm{mg} / \mathrm{dL} \text { Glicose + } \\
\text { Gox }\end{array}$} & $\mathrm{A} 1$ & 610676,00934 & 862,34273 & \multirow{4}{*}{106,94} \\
\hline & $\tau 1$ & 0,10736 & 0,00040 & \\
\hline & $\mathrm{A} 2$ & 36465,36600 & 15303,10396 & \\
\hline & $\tau 2$ & 0,00750 & 0,00280 & \\
\hline \multirow{4}{*}{$\begin{array}{c}\text { 4Eu:10Tc }+150 \\
\mathrm{mg} / \mathrm{dL} \text { Glicose + } \\
\text { Gox }\end{array}$} & A1 & 642610,02664 & 777,36218 & \multirow{4}{*}{114,12} \\
\hline & $\tau 1$ & 0,11459 & 0,00042 & \\
\hline & $\mathrm{A} 2$ & 40688,66998 & 11242,39342 & \\
\hline & $\tau 2$ & 0,00801 & 0,00216 & \\
\hline \multirow{4}{*}{$\begin{array}{c}\text { 4Eu:1OTc }+200 \\
\text { mg/dL Glicose + } \\
\text { Gox }\end{array}$} & $\mathrm{A} 1$ & 666793,47878 & 1273,20596 & \multirow{4}{*}{120,19} \\
\hline & $\tau 1$ & 0,12074 & 0,00075 & \\
\hline & $\mathrm{A} 2$ & 41634,51733 & 9365,40061 & \\
\hline & $\tau 2$ & 0,00951 & 0,00276 & \\
\hline
\end{tabular}




\section{CONCLUSÕES}

Neste trabalho foram realizados estudos espectroscópicos dos complexos európio-clorotetraciclina, európio-metaciclina e európio-oxitetraciclina na presença de peróxido de hidrogênio e peróxido de uréia. Os resultados obtidos foram comparados ao complexo európio-tetraciclina, este bastante estudado no meio científico.

Todos os complexos estudados (EuOTc, EuCTc e EuMTc) apresentaram as características típicas de um complexo lantanídeo-ligante: um grande deslocamento Stokes (aproximadamente $220 \mathrm{~nm}$ ) importante para evitar a sobreposição dos espectros de excitação e emissão; amplo espectro de absorção com pico em torno de $400 \mathrm{~nm}$ com estreita banda de emissão em $615 \mathrm{~nm}$ com forte luminescência em $\mathrm{pH}$ neutro.

$\mathrm{Na}$ presença dos peróxidos os espectros de absorção e emissão característicos se mantêm, porém com há aumento significativo na luminescência. Os complexos citados anteriormente foram comparados com o complexo EuTc.

Os resultados do complexo com PH e PHU podem ser resumidos na Tabela 16. A intensidade relativa corresponde à intensidade máxima de emissão com peróxido/ intensidade da emissão sem peróxido.

Tabela 16 - Resumo dos resultados obtidos nos estudos com peróxido de hidrogênio e peróxido de uréia.

\begin{tabular}{c|c|c|c|c|c}
\hline \multicolumn{2}{c|}{ Complexo } & $\begin{array}{c}\text { Intensidade } \\
\text { Relativa }\end{array}$ & $\begin{array}{c}\text { Linearidade } \\
(\mu \mathrm{M})\end{array}$ & $\begin{array}{c}\text { Limite de } \\
\text { Detecção }(\mathrm{mg} / \mathrm{mL})\end{array}$ & $\begin{array}{c}\text { Tempo de } \\
\text { Vida }(\mu \mathrm{s})\end{array}$ \\
\hline \multirow{4}{*}{$\mathrm{PH}$} & EuTc & 7,0 & $0-600$ & 0,17 & 68,12 \\
\cline { 2 - 6 } & EuOTc & 4,0 & $0-600$ & 0,12 & 95,13 \\
\cline { 2 - 6 } & EuCTc & 7,2 & $100-700$ & 0,06 & 17,26 \\
\cline { 2 - 6 } & EuMTc & 0,0 & - & - & 54,22 \\
\hline \multirow{4}{*}{ PHU } & EuTc & 7,0 & $0-1000$ & 0,07 & 70,87 \\
\cline { 2 - 6 } & EuOTc & 4,5 & $0-500$ & 0,24 & 85,57 \\
\cline { 2 - 6 } & EuCTc & 3,0 & $200-1000$ & 0,08 & 12,83 \\
\cline { 2 - 6 } & EuMTc & 0,0 & - & - & 53,06 \\
\hline
\end{tabular}


Os complexos EuTc-PH e EuCTc-PH foram os que obtiveram maior aumento na luminescência de até 7 vezes mais comparado ao complexo sem o peróxido. Todos os complexos apresentaram praticamente o mesmo intervalo de linearidade e bons resultados no limite de detecção sendo o complexo EuCTc-PH que obteve melhor resultado, 0,06 mg/mL. O tempo de vida das amostras EuTc-PH e EuOTc-PH praticamente dobraram o seu tempo de vida de fluorescência em relação às amostras sem peróxido. Somente a EuCTc-PH não sofreu aumento significativo no tempo de decaimento e o EuMTc-PH teve seu tempo de vida diminuido.

O complexo EuTc-PHU obteve melhor resultado. Apresentou maior aumento na luminescência, um aumento de 7 vezes, com linearidade ao longo de toda a curva de calibração, menor limite de detecção no valor de $0,07 \mathrm{mg} / \mathrm{mL}$ e dobrou seu tempo de decaimento. O complexo EuCTc apresentou um bom resultado. Mostrou-se relativamente linear em um grande intervalo e com baixo limite de detecção, com aumento de 4,5 vezes na luminescência. O tempo de vida diminuiu em relação à amostra sem o peróxido. O complexo EuOTc apresentou um pequeno aumento ( 3 vezes) na emissão com uma menor linearidade comparado aos anteriores, o maior limite de detecção, porém o tempo de decaimento aumentou consideravelmente.

Para ambos os peróxidos observa-se que o complexo EuOTc mostrou um longo tempo de vida, em torno de $90 \mu \mathrm{s}$.

O aumento da emissão com a adição do peróxido de hidrogênio ou com peróxido de uréia ocorre devido à substituição de moléculas de água nos sítios de coordenação do íon európio e a oxidação da tetraciclina pelo peróxido permitindo a complexação de mais íons $\mathrm{Eu}^{3+}$ nos sítios da tetraciclina. Os peróxidos também promovem uma reorganização estrutural do complexo em solução aproximando o íon metálico central com os ligantes orgânicos aumentando a eficiência na transferência de energia intramolecular. No complexo EuMTc não há alteração na emissão mesmo em presença de peróxidos, possivelmente porque não há um aumento no número de sítios de ligação da molécula.

Foi observado nos estudos com interferentes inorgânicos que estes compostos não promovem interferência significativa no sinal de emissão, pois 
considerando o aumento da luminescência em relação ao complexo EuTC sem a presença dos peróxidos, a interferência torna-se irrelevante.

Assim um biossensor para $\mathrm{PH}$ e PHU mostra-se possível também para os complexos EuCTc e EuOTc. No caso do PHU o complexo EuTc ainda mostrou-se como a melhor opção para a detecção do peróxido, possibilitando a criação de um método mais rápido, direto e de menor custo que pode ser realizado em temperatura ambiente e ser observado sem a necessidade de condições especiais, já que a emissão da luz é em uma região visível.

Os complexos EuCTc e EuOTc também mostraram-se eficientes na detecção de glicose. O método baseia-se na adição da enzima glicose oxidase que promove a quebra da glicose em ácido glicônico e peróxido de hidrogênio, que em presença do complexo EuTC possui forte luminescência na região de $615 \mathrm{~nm}$. Todos os complexos apresentaram um aumento na emissão, baixo limite de detecção e relativa linearidade até aproximadamente $125 \mathrm{mg} / \mathrm{dL}$ de glicose. Foi observado nos experimentos um aumento gradativo no tempo de vida conforme o aumento da concentração de glicose na amostra. O complexo EuOTc para $200 \mathrm{mg} / \mathrm{dL}$ de glicose mostrou um tempo de vida de $120 \mu \mathrm{s}$, o dobro do valor obtido sem a presença de glicose. Logo o método para determinação de glicose é promissor. 
REFERÊNCIAS BIBLIOGRÁFICAS 
1 WEISSMAN, S. I. Intramolecular energy transfer - The fluorescence of complexes of europium. J. Chem. Phys., v. 10, n. 4, p. 214-217, 1942.

${ }^{2}$ HIRSCHY, L.M.; DOSE, E.V.; WINEFORDNER, J.D. Lanthanide-sensitized luminescence for the detection of tetracyclines. Anal. Chim. Acta, v. 147, n. MAR, p. 311-316, 1983.

3 ARNAUD, N.; GEORGES, J. Comprehensive study of the luminescent properties and lifetimes of Eu3+ and Tb3+ chelated with various ligands in aqueous solutions: influence of the synergic agent, the surfactant and the energy level of the ligand triplet. Spectrochim. Acta A., v. 59, n. 8, p. 1829-1840, 2003.

${ }^{4}$ MATTOS, I.L.; SHIRAISHI, K.A.; BRAZ, A.D.; FERNANDEZ, J.R. Hydrogen Peroxide: importance and determination. Quim. Nova, v. 26, n. 3, p. 373-380, 2003.

${ }^{5}$ SINENSKY, M.C.; LEISER, A.L.; BABICH, H. Oxidative stress aspects of the cytotoxicity of carbamide peroxide: in vitro studies. Toxicol. Lett., n. 75, p.101-109, 1995.

${ }^{6}$ WOLFBEIS, O. S.; DÜRKOP, A.; WU, M.; LIN, Z. Europium ion-based luminescent sensing probe for hydrogen peroxide. Angew. Chem. Int., n. 41, p. 4495-4498. 2002.

${ }^{7}$ COURROL, L. C.; SILVA, F. R. D.; TARELHO, L. V. G.; BELLLNI, M. H.; MANSANO, R. D.; GOMES, L.; VIEIRA, N. D. Enhancement of europium luminescence in tetracycline-europium complex in the presence of urea hydrogen peroxide. J. Fluoresc.; v. 15, n. 5, p.667-671, 2005.

8 MARTINS, T. S.; ISOLANI, P. C. Rare earths: Industrial and biological applications. Quim. Nova, v. 28, n. 1, p. 111-117, 2005.

${ }^{9}$ ROSENTAL, S.; Terras-Raras, CETEM/CNPq: Rio de Janeiro, Brasil, 2008.

${ }^{10}$ DE SÁ, G. F.; MALTA, O. L.; DE MELLO DONEGÁ, C.; SIMAS, A. M.; LONGO, R. L.; SANTA-CRUZ,P.A.; DA SILVA, E. F. Spectroscopic properties and design of highly luminescent lanthanide coordination complexes. Coordin. Chem. Rev., v. 196, n. 1, p. 165195, 2000.

${ }^{11}$ SABBATINI, N.; GUARDIGLI, M.; MANET, I.; UNGARO, R.; CASNATI, A.; ZIESSEL, R.; ULRICH, G.; ASFARI, Z.; LEHN, J. M. Lanthanide Complexes Encapsulating ligands luminescent devices at the molecular level. Pure Appl. Chem., v. 67, n. 1, p. 135-140, 1995.

${ }_{12}$ MAAS, H.; CURRAO, A.; CALZAFERRI, G. Encapsulated Lanthanides as Luminescent Materials. Angew. Chem. Int. v. 41, n. 14, p. 2495-2497, 2002.

${ }^{13}$ SELVIN, P.R.; JANCARIK, J.; LI, M.; HUNG, L. Crystal Structure and Spectroscopic Characterization of a Luminescent Europium Chelate. Inorg. Chem. v. 35, n. 3, p. 700-705, 1996.

${ }^{14}$ HORROCKS, W.; SUDNICK, D.R. Lanthanide Ion Luminescence Probes of the Structure of Biological Macromolecules. Am Chem. Soc. v. 14, p 376-384, 1981. 
${ }_{15}$ TURRO, C.; FU, P.K.L.; BRADLEY, P.M. Lanthanide lons as Luminescent Probes of Proteins and Nucleic Acids. Departamento de química da Universidade de Ohio. USA.

16 DURKOP, A. Luminescent Metal-Ligand Complexes as Labels for Polarization Immunoassays and for determination of Hydrogen Peroxide. 2001. Tese (Doutorado) Faculdade de Química e Farmácia da Universidade de Regensburg, Alemanha.

${ }^{17}$ BROWN, T.L.; LEMAY, H.E; BURSTEN, B.E. Química a Ciência Central. 9. ed. São Paulo: Pearson Education, 2005. p. 884-889.

${ }_{18}$ LIS, S.; ELBANOWSKI, M.; HNATEJKO, Z. Energy transfer in solution of lanthanide complexes. J. Photoch. Photobio. A.. v. 150, n.1-2, p. 233-247, 2002.

${ }^{19}$ LIS, S. Luminescence spectroscopy of lanthanide(III) ions in solution. J. Alloy Compd., v. 341, n. 1-2, p. 45-50, 2002.

${ }^{20}$ CHEN, J. Y.; SELVIN, P. R. Lifetime- and color-tailored fluorophores in the micro- to millisecond time regime. J. Am. Chem.Soc., v. 122, n. 4, p. 657-660, 2000.

${ }^{21}$ SILVA, P. Farmacologia. 7. ed. Rio de Janeiro: Guanabara Koogan, 2006. p. 988.

22 CHOPRA, I.; ROBERTS, M. Tetracycline antibiotics: Mode of action, applications, molecular biology, and epidemiology of bacterial resistance. Microbiol. Mol.Biol. R., v. 65, n. 2, p. 232-260, 2001.

23 KURITTU, J. et al. Detection of tetracyclines with luminescent bacterial strains. Luminescence, v. 15, n. 5, p. 291-297, 2000.

${ }^{24}$ HANG H.P.; DALE N.M.; RITTER J.M. Farmacologia. 4.ed. Rio de Janeiro: Guanabara Koogan, 2001. p. 366.

${ }^{25}$ ZHAO, F. N.; ZHANG, XZ; GAN, YR. Determination of tetracyclines in ovine milk by highperformance liquid chromatography with a coulometric electrode array system. $J$. Chromatogr. A, v. 1055, n. 1-2, p. 109-114, 2004.

${ }^{26}$ SACHAN, N. P.; GUPTA, C.M. Talanta, v. 27, p. 457, 1980.

${ }^{27}$ CROSBY, G.A.; WHAN R.E.; ALIRE R.M. Intramolecular energy transfer in rare earth chelates - role of triplet state. J. Chem.I Phys., v. 34, n. 3, p. 743-747, 1961.

${ }^{28}$ CROSBY, G.A.; WHAN R.E.; FREEMAN J.J. Spectroscopic studies of rare earth chelates. J. Phys. Chem., v. 66, n. 12, p. 2493-\&, 1962.

${ }^{29}$ RICHARDSON, F. S. Terbium(III) and Europium(III) ions as luminescent probes and stains for biomolecular systems. Chem. Rev., v. 82, n. 5, p. 541-552, 1982.

30 HIRSCHY, L.M.; VANGEEL, T.F.;WINEFORDNER, J D.;KELLY, R N.;SCHULMAN, S.G. Characteristics of the binding of europium(III) to tetracycline. Anal. Chim. Acta, v. 166, n. 12, p. 207-219, 1984. 
${ }^{31}$ SELVIN, P. R. Lanthanide-based resonance energy transfer. leee J. Sel. Top. Quant., v. 2, n. 4, p. 1077-1087, 1996.

${ }^{32}$ DIAMANDIS, E.P.; CHRISTOPOULOS, T.K. Europium chelate labels in time-resolved fluorescence immunoassays and DNA hybridization assay. Anal. Chem., v. 62, n. 22, p.1149A-1157A, 1990.

${ }^{33}$ GEORGES, J. Lanthanide-sensitized luminescence and applications to the determination of organic analytes, Analyst, v. 118, n.12, p. 1481-1486, 1993.

${ }^{34}$ SELVIN, P. R. Principles and biophysical applications of lanthanide-based probes. Annu. Rev. Bioph. Biom., v. 31, p. 275-302, 2002.

${ }^{35}$ YATSIMIRSKII, K. B.; DAVIDENKO, N. K. Absorption spectra and structure of lanthanide coordination compounds in Solution. Coordin. Chem. Rev., v. 27, n. 3, p. 223-273, 1979.

${ }^{36}$ ARNAUD, N.; GEORGES, J. Sensitive detection of tetracyclines using europium-sensitized fluorescence with EDTA as co-ligand and cetyltrimethylammonium chloride as surfactant. Analyst., v. 126, n. 5, p. 694-697, 2001.

${ }^{37}$ RODRIGUEZ-DIAZ,R.C;AGUILAR-CABALLOS,M.P.;GOMEZ-HENS,A. Simultaneous determination of ciprofloxacin and tetracycline in biological fluids based on dual-lanthanide sensitised luminescence using dry reagent chemical technology. Anal. Chim. Acta, v. 494, n. 1-2, p. 55-62, 2003.

${ }^{38}$ WU, M.; LIN, Z.; SCHAFERLING, M.; DURKOP, A.; WOLFBEIS, O.S. Fluorescence imaging of the activity of glucose oxidase using a hydrogen peroxide sensitive europium probe. Anal Biochem., v. 340, p. 66-73, 2005.

39 ZHU, X.; WANG, X.; JING, C. Spectrofluorimetric determination of heparin using a tetracycline europium, Probe. Anal Biochem., v. 341, n. 2, p. 299-307, 2005.

${ }^{40}$ COURROL, L. C.; BELLINI, M. H.; TARELHO, L. V. G.; SILVA, F. R. O.; MANSANO, R. D.; GOMES, L.; VIEIRA, N. D.; SHOR, N. Urea hydrogen peroxide determination in whole blood using europium tetracycline probe. Anal. Biochem., v. 355, n. 1, p. 140-144, 2006.

${ }^{41}$ ZEPP, R. G.; FAUST, B.C.; HOIGNE, J. Hydroxyl radical formation in aqueous reactions $(\mathrm{pH} 3-8)$ of iron (II) with hydrogen-peroxide - the photo-fenton reaction. Environ. Sci. Technol., v. 26, n. 2, p. 313-319, 1992.

42 ZEPP, R. G.; SCHLOTZHAUER, P. F.; SINK, R. M. Photosensitized transformations involving electronic-energy transfer in natural waters - role of humic sibstances. Environ. Sci. Technol., v. 19, n. 1, p. 74-81, 1985.

${ }^{43}$ PRICE, D.; WORSFOLD,P.J.; MANTOURA, R. F. C. Hydrogen-peroxide in the marine environment - cycling and methods of analysis. Trac-Trend Anal. Chem., v. 11, n. 10, p. 379-384, 1992.

${ }^{44}$ THOMPSON, A. M. The oxidizing capacity of the earths atmosphere - probable past and 
the future changes. Science, v. 256, n. 5060, p. 1157-1165, 1992.

${ }^{45}$ ANGLADA, J. M.; APLINCOURT, P.; BOFILL, J. M.; CREMER, D. Atmospheric formation of $\mathrm{OH}$ radicals and $\mathrm{H}_{2} \mathrm{O}_{2}$ from alkene ozonolysis under humid conditions. Chemphyschem, v. 3, n. 2, p. 215-221, 2002.

${ }^{46}$ CHEN,J.;RULKENS,W.H.;BRUNING, H. Photochemical elimination of phenols and cod in industrial wastewaters. Water Sci.Technol., v. 35, n. 4, p. 231-238, 1997.

${ }^{47}$ VIJAYAKUMAR, A. R.; CSOREGI, E.; HELLER, A.; GORTON, L. Alcohol biosensors based on coupled oxidase-peroxidase systems. Anal. Chim. Acta, v. 327, n. 3, p. 223-234, 1996.

${ }^{48}$ WU,M; LIN,Z.H.; DURKOP,A.; WOLFBEIS, O. S. Time-resolved enzymatic determination of glucose using a fluorescent europium probe for hydrogen peroxide. Anal. Bioanal. Chem., v. 380, n. 4, p. 619-626, 2004.

49 TKAC,J; STURDIK,E.; GEMEINER, P. Novel glucose non-interference biosensor for lactose detection based on galactose oxidase-peroxidase with and without co-immobilised beta-galactosidase. Analyst, v. 125, n. 7, p. 1285-1289, 2000.

${ }^{50}$ GORENEK,G.; AKYILMAZ,E.; DINCKAYA, E. Immobilization of catalase by entrapping in alginate beads and catalase biosensor preparation for the determination of hydrogen peroxide decomposition. Artif. Cell Blood Sub., v. 32, n. 3, p. 453-461, 2004.

${ }^{51}$ WU, M.; LIN, Z.; WOLFBEIS, S. Determination of the activity of catalase using a europium(III)-tetracycline-derived fluorescent substrate. Anal. Biochem., v. 320, n. 1, p. 129135, 2003.

${ }^{52}$ RAKICIOGLU, Y.; PERRIN, J. H.; SCHULMAN, S. G. Increased luminescence of the tetracycline-europium(III) system following oxidation by hydrogen peroxide. J. HParm. Biomed. Anal., n. 20, p. 397-399, 1999.

${ }^{53}$ LEI, W.; DUERKOP, A.; WU, M.; WOLFBEIS, O. S. Determination of hydrogen peroxide in river water using a europium tetracycline microplate luminescence assay with time-resolved ("gated") detection. Microchim. Acta, n. 143, p. 269-274, 2003.

${ }^{54}$ OSZWALDOWSKI,S.; LIPKA,R.; JAROSZ, M. Sensitive reversed-phase liquid chromatographic determination of hydrogen peroxide and glucose based on ternary vanadium(V)-hydrogen peroxide-2-(5-bromo-2-pyridylazo)-5-diethylaminophenol system. Anal. Chim. Acta , v. 421, n. 1, p. 35-43, 2000.

55 HANKS, C.T.; FAT, J.C; WATAHA, J.C.; CORCORAN, J.F. Cytotoxicity and Dentin Permeability of Carbamide Peroxide and Hydrogen Peroxide Vital Bleaching Materials, in vitro. J. Dent. Res., v. 72, n. 5, p. 931-938, 1993.

${ }^{56}$ SILVERTHORN, D.U. Fisiologia Humana - uma abordagem integrada. 2 ed. São Paulo: Manole, 2003.

${ }^{57} \mathrm{MOH}, \mathrm{A} . ; \quad$ SAKATA,N.; TAKEBAYASHI,S.; TATEISHI,K.; NAGAI,R.; HORIUCHI,S.; $\mathrm{CHIHARA}, \mathrm{J}$. Increased production of urea hydrogen peroxide from Maillard reaction and a 
UHP-Fenton pathway related to glycoxidation damage in chronic renal failure. J.Am. Soc. Nephrol., v. 15, n. 4, p. 1077-1085, 2004.

${ }^{58}$ MONNIER,V.M.; SELL,D.R.; NAGARAJ,R.H.; MIYATA,S.; GRANDHEE,S.; ODETTI,P.; IBRAHIM, S. A maillard reation-mediated molecular damage to extracellular-matrix and other tissue proteins in diabetes, aging and uremia. Diabetes, v. 41, p. 36-41, 1992.

59 ALBERTI, K.G.M.M.; ZIMMET, P.Z., for the World Health Organization Consultation. Definition,diagnosis and classification of diabetes mellitus and its complications. Part 1: Diagnosis and classification of diabetes mellitus. Report of a WHO Consultation. Geneva: WHO;1999.

${ }^{60}$ The Expert Committee on the Diagnosis and Classification of Diabetes Mellitus. Report of the Expert Committee on the Diagnosis and Classification of Diabetes Mellitus, Diabetes Care. v. 25, supplement 1, p. S5-S20, 1997.

${ }^{61}$ GROSS, Jorge L.; SILVEIRO, S.P.; CAMARGO, J.J.; REICHELT, A.J. Diabetes Melito: Diagnóstico, Classificação e Avaliação do Controle Glicêmico. Arq. Bras. Endocrinol. Metab., São Paulo, v. 46, n. 1, 2002. Disponível em: <http://www.scielo.br/scielo.php? script=sci_arttext\&pid=S0004-27302002000100004\&Ing=en\&nrm=iso>. Acesso em: 30 abr. 2010.

${ }^{62}$ WALKER, H.K.; HALL, W.D.; HURST J.W. Clinical Methods: the history, physical and laboratory examinations. 3.ed. Disponível em: < http://www.ncbi.nlm.nih.gov/bookshelf/br.fcgi?book=cm\&part=A4187 >. Acesso em: 30 abr. 2010.

${ }^{63}$ MOTTA, V.T. Bioquímica Clínica: Princípios e Interpretações. v.7. Disponível em: < http://www.labclinisul.com.br/artigos/Bioq.Clinica\%20-\%20Carboidratos.pdf >. Acesso em: 30 abr. 2010.

${ }^{64}$ SEILER, H.G.; SIGEL, A.; SIGEL, H. Handbook on metals in clinical and analytical chemistry. New York: Marcel Dekker, 1994.

${ }^{65}$ GITELMAN, H. J. Aluminum and Health: a critical review. Nova York: Marcel Dekker, 1989.

${ }^{66}$ ANDRIOLO, A. Guia de medicina ambulatorial e hospitalar da UNIFESP. São Paulo: Manole, 2006. p. 256.

67 MANUAL MERCK. Exames Laboratoriais e de Diagnóstico Comuns. Disponível em:<http://mmspf.msdonline.com.br/pacientes/manual_merck/secao_00/apendice_II.html>. Acesso em: 5 Mar. 2010.

${ }^{68}$ PERRELLI, G.; PIOLATTO, G. Tentative reference values for gold, silver and platinum: literature data analysis. Sci.Total Environ, v. 120, n. 1-2, p.93-96, 1992.

69 BRASIL. ANVISA. Guia para validação de métodos analíticos e bioanalíticos. Disponível em: < http://www.anvisa.gov.br/legis/resol/2003/re/899_03re.htm>. Acesso em: 3 
Mar. 2010. 